NBER WORKING PAPER SERIES

HOW DID PRE-FED BANKING PANICS END?

\author{
Gary Gorton \\ Ellis W. Tallman \\ Working Paper 22036 \\ http://www.nber.org/papers/w22036
NATIONAL BUREAU OF ECONOMIC RESEARCH
1050 Massachusetts Avenue
Cambridge, MA 02138
February 2016

The authors thank Jeremy Atack, Howard Bodenhorn, Michael Bordo, Charles Calomiris, Andrew Coleman, Ben Craig, Stanley Engerman, Kinda Hachem, Eric Hilt, Gary Kornblith, Arvind Krishnamurthy, Jon Moen, Hugh Rockoff, George Selgin, Larry Wall, Warren Weber, David Weiman, Eugene White as well as the participants at the Conferences in Honor of Elmus Wicker and in Honor of Hugh Rockoff, the 2015 Atlanta Fed Monetary and Financial History Conference and the Monetary Economics Workshop at 2015 NBER Summer Institute for helpful comments. They thank Bob Chakravorti and Mirjana Orovic for assistance with the New York Clearing House Association Archives. They also thank George Berry, Thomas Bonczek, Jialu Chen, Paulo Costa, Arun Gupta, Yiming Ma, Markus Shak, and Arwin Zeissler for research assistance. The views expressed herein are those of the authors and do not necessarily reflect the views of the National Bureau of Economic Research, the Federal Reserve Bank of Cleveland or the Federal Reserve System.

NBER working papers are circulated for discussion and comment purposes. They have not been peerreviewed or been subject to the review by the NBER Board of Directors that accompanies official NBER publications.

(C) 2016 by Gary Gorton and Ellis W. Tallman. All rights reserved. Short sections of text, not to exceed two paragraphs, may be quoted without explicit permission provided that full credit, including $\odot$ notice, is given to the source. 
How Did Pre-Fed Banking Panics End?

Gary Gorton and Ellis W. Tallman

NBER Working Paper No. 22036

February 2016

JEL No. E32,E42,E44,E58

\begin{abstract}
$\underline{\text { ABSTRACT }}$
How did pre-Fed banking crises end? How did depositors' beliefs change? During the National Banking Era, 1863-1914, banks responded to the severe panics by suspending convertibility, that is, they refused to exchange cash for their liabilities (checking accounts). At the start of the suspension period, the private clearing houses cut off bank-specific information. Member banks were legally united into a single entity by the issuance of emergency loan certificates, a joint liability. A new market for certified checks opened, pricing the risk of clearing house failure. Certified checks traded at a discount to cash (a currency premium) in a market that opened during the suspension period. Confidence was restored when the currency premium reached zero.
\end{abstract}

\title{
Gary Gorton
}

Yale School of Management

135 Prospect Street

P.O. Box 208200

New Haven, CT 06520-8200

and NBER

Gary.Gorton@yale.edu

Ellis W. Tallman

Federal Reserve Bank of Cleveland

ellis.tallman@clev.frb.org 


\section{Introduction}

In a financial crisis, holders of short-term bank debt want cash not the bank debt, which they have doubts about. Yet, sometime later the same lenders/depositors are happy to hold short-term bank debt again. In this paper we ask why lenders' beliefs switch from "panic" to "not panic." A crisis is a systemic event in which all banks are affected; the issue for depositors is whether the banking system is solvent. How can depositors be convinced that the banking system is solvent? We focus on the U.S. National Banking Era (1863-1913), a particularly interesting period to study because there was no central bank, so expectations of possible central bank interventions during a crisis are not an issue. We use the period of the suspension of convertibility of bank deposits into cash as a laboratory to study how depositors' beliefs change during crises.

The argument of this paper is broadly as follows. A financial crisis is a systemic event, an information event in which depositors observe unexpected information that a recession is looming (see Gorton (1988)). They run on their banks. To convince panicky depositors that the banking system is solvent the clearing house focuses attention on itself (essentially the banking system in the case of the New York Clearing House Association), suppressing bank-specific information. A suspension of convertibility occurs, during which only aggregate information about the clearing house was released, in particular the Reserve Surplus (reserves relative to required reserves). The clearing house took the lead in managing information, through special bank examinations. And bank bailouts of individual members were part of managing the information environment and hence expectations. At the start of the suspension period, the clearing house transformed into a single institution by issuing loan certificates and certified checks which were the joint liabilities of the clearing house members. (See Timberlake (1984), Gorton (1985b) and Gorton and Mullineaux (1987).) These new financial instruments resulted in a new market opening, where these instruments traded publicly at a "currency premium," e.g., to buy $\$ 1.00$ of currency required a $\$ 1.05$ of certified checks -- a 5 percent premium. The currency premium was a measure of systemic bank risk, excess demand for cash because of fears that the clearing house might be insolvent. ${ }^{1}$ It focused attention on systemic risk, rather than individual bank risk. The premium started high and over time it (non-monotonically) declined. Eventually, convertibility was resumed. In short, the information environment was managed by the clearing house so that systemic risk was reflected in the currency premium. When that went to zero, resumption occurred.

The pre-Fed clearing house actions in a crisis were similar to those of modern central banks during crises. During the 2007-2008 financial crisis the government (Federal Reserve System, U.S. Treasury, and

\footnotetext{
${ }^{1}$ The currency premium during these $19^{\text {th }}$ century panics also has a counterpart in modern financial crises. The currency premium arises because cash and certified checks are not perfect substitutes. People prefer cash. Cash has a higher "convenience" yield. The counterpart in the modern area is also any measure of the convenience yield on U.S, Treasuries. For example, the spread between the interest rate paid on general collateral repo, repo backed by a U.S. Treasury bond as collateral and the yield on the same Treasury bond. See, e.g., Xie (2012). Such measures spiked during the Financial Crisis of 2007-2008 because U.S. Treasuries were preferred over privatelyproduced assets. This is the flight to quality.
} 
the Securities and Exchange Commission) adopted five policy responses. First, new anonymous lending programs were put into place, including the Term Auction Facility, the Term Securities Lending Facility, and the Primary Dealers Credit Facility. These programs were designed to make loans in secret, protecting the anonymity of borrowers in order to avoid identifying weak banks, which might then face runs. The Federal Reserve's discount window is regarded as being unable to maintain the secrecy of borrower identity. Borrowers become stigmatized if their name is revealed. ${ }^{2}$ Second, in an attempt to prevent revelation of weak financial institutions, the SEC instituted short-sale bans on the stock of 797 financial firms starting on September $18,2008 .{ }^{3}$ Third, the Federal Reserve conducted stress tests on large banks, and publicly summarized the results with the amount of new capital each bank needed to raise. ${ }^{4}$ Fourth, some financial institutions were effectively bailed out, notably the investment bank Bear Stearns and the insurance company American International Group (AIG). And fifth, the Federal Reserve lowered the policy rate to near zero. These policies appear to have been successful in avoiding another depression.

With the exception of the central bank lowering the policy rate, these responses have a long history in the United States prior to the advent of the Federal Reserve System. During the National Banking Era the central banking institution was the private bank clearing house. And, the clearing house-and in particular we will focus on the New York Clearing House Association, as explained below - played a central role in National Banking Era panics. This is not surprising because demand deposits need to be "cleared." Bank checks cannot exist without clearing houses. The clearing house is the central location and the set of mutually agreed rules that determine the exchange of net check positions among banks on a daily basis. The process exposes member banks to counterparty risk because each bank at some date will be owed a potentially very large amount of cash by another member bank. As a result of this counterparty risk problem, the clearing house developed supervisory and central bank-like roles.

During a severe banking panic the clearing house engaged in the same first four policy responses mentioned above. First, there was anonymous lending via clearing house loan certificates, which were

\footnotetext{
${ }^{2}$ See Bernanke (2009) for more specific information about the lending programs. On "stigma" during the financial crisis see Armantier et al (2011). Also, see Anbil (2014).

${ }^{3}$ See SEC Release 34-58592 (http://www.sec.gov/rules/other/2008/34-58592.pdf), "Emergency order pursuant to section 12(k)(2) of the Securities Exchange Act of 1934 taking temporary action to respond to market developments," September 18, 2008. Similar bans were put in place in England and in many European and other developed market regulators temporarily banned the short-selling of the stock of financial firms after September 2008. Also, on May 19, 2010, the German Federal Financial Supervisory Authority (BaFin) prohibited naked short sales of euro-denominated government bonds, naked CDSs based on those bonds, and also naked short sales of the stock of Germany's ten largest financial institutions. "Naked" short-selling means selling a security when the seller has not borrowed the security. Such a ban prevents short-selling in excess of the existing supply of securities available to borrow, and can be viewed as a method to restrain "excessive" short sales. See Gruenewald, Wagner and Weber (2010) for a list of worldwide short-selling bans that were instituted during the financial crisis. Appel and Fohlin (2010) argue that the short sale prohibition created liquidity. But Beber and Pagano (2013) find the opposite result. In Europe naked CDS on sovereign debt was also banned (EU Short Selling Regulation (236/2012). ${ }^{4}$ See http://www.federalreserve.gov/bankinforeg/stress-tests-capital-planning.htm . On the information effects of the stress tests see Peristian, Morgan and Savino (2010) and Bayazitova and Shivdasani (2012).
} 
ultimately the joint liabilities of the clearing house members and came into existence only during panics. Member banks could deposit specified collateral with a clearing house committee and receive loan certificates that could be used in the clearing process and in later panics were also handed out to the public in small denominations (from clearing houses other than the New York Clearing House). The borrowing amounts of each bank were kept secret. The clearing house suppressed their normal requirement that member banks release balance sheet information to the press each week. Like the short sale constraints, this suppression of information avoided revealing weak banks. The clearing house also conducted special examinations of banks during the suspension period (similar to the stress tests) and then announced publicly only that the bank was solvent; no details were supplied. Finally, the clearing house effectively organized (and funded) depositor bailouts of member banks. The clearing house's management of the crisis re-created confidence in the banking system.

We show that there was a specific timing of events that leads back to normalcy. First, the currency premium must become zero reflecting the belief that the clearing house is solvent, with the implied probability of systemic default going from 80 percent to zero. When the currency premium became zero, fears that the banking system was insolvent had faded. Only then does resumption of convertibility occur. Subsequent to that the Reserve Surplus (clearing house reserves in excess of required reserves) becomes positive. And finally, individual bank data starts being published again, but there is a delay of about a month. Notably, the Reserve Surplus, which becomes negative at the start of the panic, does not have to be positive prior to resumption but display an upward trend. In the aftermath there were few bank failures and no losses to the clearing house on loan certificates.

The paper proceeds as follows. In Section 2 we provide background on the New York Clearing House Association and, in particular, the information environment for banks and depositors during non-panic times. In Section 3 we start our examination of the responses to panics by the New York Clearing House. In Section 4 we detail Clearing House special bank examinations and bank bailouts during suspension periods. In the Panics of 1884 and 1890 clearing house loan certificates were issued and bank-specific information was cut off (briefly), but there was no widespread suspension of convertibility. We think of these panics as having been addressed successfully early and they are discussed in Section 5. In Section 6 the currency premium on certified checks is examined. A certified check was essentially a pure discount bond, a claim to the checks amount at a future date, selling at a discount to the par value. The discount implies a probability of the New York Clearing House, and essentially the banking system, defaulting. Over the suspension period the premium goes to zero and the checks were then redeemed. The change in depositors" beliefs during the suspension period is the focus of Section 7 and summarizes the events and their timing to show how depositors changed their beliefs about banks. Section 8 looks at the aftermath of suspensions in terms of NY Clearing House failures and Clearing House losses on loan certificates. Section 9 is a conclusion.

\section{The New York Clearing House Association}

The National Banking Era was inaugurated with a series of Acts of Congress, starting in 1863. The legislation established "national banks" which could issue national bank notes backed by government 
bonds. National bank notes, which were required to be backed by U.S. Treasury bonds, became the dominant form of currency. The new system replaced the previous state-regulated banking systems, which allowed banks to issue their own private monies. While banks could continue to be chartered at the state level, private bank notes disappeared due to a prohibitive tax on their issuance.

We focus on New York City, the center of American finance in the $19^{\text {th }}$ century, and home to the New York Clearing House Association. Just prior to the Panic of 1873 seven New York City banks (out of a total of 50) held between 70 and 80 percent of all banks deposits (net banker balances) of the country (Sprague 1910, p. 17). According to Sprague (1910), "These 7 banks were directly responsible for the satisfactory working of the credit machinery of the country. . " (p. 15). Sprague (1910, p. 126), citing Annual Reports of the Comptroller of the Currency for 1889, 1890 and 1891, says that of 3,438 national banks in 1890, all but three drew drafts on banks in New York City, and the total amount of these drafts was 61.3 percent of all the drafts drawn on banks in the U.S. ${ }^{5}$

The New York Clearing House Association was founded June 6, 1854 when its constitution was adopted; see Gibbons (1859, p. 296 ff). It was founded because demand deposits had grown significantly, especially in large cities. ${ }^{6}$ The constitution evolved as the clearing house association learned about which policies were necessary to maintain the integrity of the institution. For example the Clearing House Committee could require any member of the New York Clearing House to submit securities "of a sufficient amount" to protect the clearing house membership from exchange positions of a member that may threaten it. Further "learning" took place in the operations of the Clearing House Loan Committees, whose establishment in emergencies preceded the issue of any clearing house loan certificates. ${ }^{7}$

Camp (1892), the manager of the New York Clearing House: "It was asserted by a prominent bank president, at a meeting of the Association, during the panic of 1884, that the influence of the New York Clearing House in this country was greater than that of the Bank of England in Great Britain, and those experienced in its history accord with that opinion" (p. 686).

\section{A. Information and the Process of Clearing Checks}

The transition from bank notes to checks in the United States began in a significant way prior to the Civil War. See Gorton (2013). The system of bank notes that dominated bank money prior the Civil War required clearing but this happened through informal secondary markets. In principle, bank notes did

\footnotetext{
${ }^{5}$ For an extensive examination of the New York City banks as the "clearing house" of the United States, see James and Weiman (2010).

${ }^{6}$ On U.S. clearinghouses generally, see Gibbons (1859), Squire (1888), Curtis (1898), Bolles (1903), Cannon (1910a), Gorton (1984), Timberlake (1984), Gorton (1985b), and Gorton and Mullineaux (1987) and Gorton and Huang (2006) for theory.

${ }^{7}$ Article VI, Section 5, New York Clearing House Constitution 1908 -- the same point is highlighted below as an amendment accepted in 1884.
} 
not need to be cleared, that is, be taken back to the issuing bank and exchanged for coin. But, in practice note brokers would buy notes at advantageous discounts and return the notes to the issuing bank to make an arbitrage profit. The note discounts were printed in newspapers called "bank note reporters." These discounts came from informal secondary markets in each large city. The note discounts were informative. See Gorton $(1996,1999)$. But, while informative, this also made the notes difficult to use as transaction media due to disputes about their value.

Since checks are claims on an individual's account at a specific bank, a person did not write enough checks to make it profitable for note brokers to make a market in the checks. This is the origin of clearing. As explained further in Gorton (2013), this has important information implications for banking. On the one hand, without clearing via markets bank checks could be used for transactions without the nettlesome discounts (but the person's solvency had to be verified). On the other hand, an informative market about bank risk was closed. When checks supplanted bank notes, two things happened: 1) the clearing house internalized what had been an informative securities market for bank notes (by internalizing the market, the clearing house implicitly transfers the arbitrage profits from discounts to banks and customers), and 2) because check clearing involves multi-lateral netting, credit and debit balances among the group of banks involved in clearing become intertwined leading to heightened incentives to monitor other banks.

The raison d'etre of clearing houses was to "clear" checks. What does that mean? Squire (1888):

Each member of the Clearing House Association, in its daily routine of business, receives a large number of items, consisting of checks, drafts, etc., on other banks. When the business of the day is ended, these items are due to them in various sums by other banks, and in like manner the bank itself is debtor to other banks. Before the establishment of the Clearing House, each bank found it necessary every morning, to make up its accounts with every other bank, and to send its messenger to present the bills, checks, drafts, and other items held by it to the bank for payment. The indebtedness was adjusted by payment of gold and banknotes. (p. 8)

Hence, prior to a central clearing house, individual banks would settle their balances bilaterally with each bank for which it had transactions, either debit or credit (most often both). The following paragraph from Squire (1888) describes the efficiency relative to each bank sending a representative to every other bank each morning to settle accounts of the previous day:

Each Delivery Clerk advances to the next desk at which he delivers the exchanges and receipt list; each Settling Clerk upon receipt of the exchange, receipts for it, and enters it on his settling sheet opposite the name of the bank from which he received it; thus the exchanges continues until every bank has been visited, and the Delivery Clerk has returned to the desk occupied by his bank. ... In about ten minutes the exchanges have been made, and the Settling Clerk has entered on his settling sheet, opposite the name of the banks, the various exchanges he has received, thus having a record on his sheet, 
of the amount brought, and the amount received from each bank. . . . he foots up the aggregate he has received from various banks, and then makes a ticket called Debit Ticket, which is sent to the Proof Clerk on the platform. . . . The differences are generally announced in about half an hour. . By three o'clock the settlements of the transactions are completed. ... (p. 8-14)

The settlement is accomplished through the use of certificates, to avoid the daily risk and expense of moving currency and coin around to settle. Gibbons (1859), Squire (1888), Cannon (1910) and Thrall (1916) provide details of the clearing process. These certificates were different from the "clearing house loan certificates" issued during panics.

It is clear from the above description that clearing creates counterparty risk. Although the process of clearing occurred on every business day, still each bank could end up exposed to the risk that another bank would not be able to honor its obligations. In the bank note market this was the risk that market makers took, rather than other banks. In the clearing system then clearing house member banks had strong incentives to monitor members (mutually) and to screen new members. This was the basis for the clearing house to enforce regulations like the one mentioned above in which the clearing house demands that a member bank submits additional securities in the event of unfavorable exchanges. It was also the basis for clearing house bank examinations, which we detail below.

\section{B. Bank Stock Prices}

Banks create money-short-term debt. It is efficient for the money to be able to trade at par (see Gorton and Pennacchi (1990), and Dang, Gorton and Holmström (2013)). Dang, Gorton, Holmström, and Ordonẽz (2012) argue that banks are optimally opaque so that the value of the debt banks produce does not fluctuate. This property is what makes bank debt useful as money. But, to keep bank debt at par, information cannot leak out about the bank, in particular via their stock prices. Bankers during the National Banking Era also made this point. For example, one banker in 1910 commented that if the public thought of bank stocks the way they thought of the stock of nonbanks, then the resulting fluctuations in prices could cause runs on the banks (Bankers Magazine September 1910, p. 337). This may explain why banks paid low dividends and tended to have high stock prices (i.e. they did not split their stocks). Bank stocks then tended to be purchased by rich investors (see "Bank Stocks as Investments," Forum (July, 1925, p. 6)). During the National Banking Era it seems that banks endogenously acted to make their stock prices less revealing by making their stock highly illiquid. That is, the banks themselves suppressed information that would be revealed from liquid bank stocks. ${ }^{8}$

Whatever the reason, during the National Banking Era bank stocks were "not widely traded" (see O'Sullivan 2007, p. 517). Bank stocks were listed on the New York Stock Exchange prior to the Civil War,

\footnotetext{
${ }^{8}$ Bank stocks did change owners and stock prices and transactions are listed in newspapers. But, transactions are fairly sparse and the prices are often described as from the last transaction, which may have been sometime considerably earlier.
} 
but afterwards migrated to the over-the-counter market because they were so illiquid (see O'Sullivan, 2007, p. 517-18). This is consistent with Goetzmann, Ibbotson and Peng (2001) who collected stock price data for the period 1815 to 1925 for active stocks. This is the most comprehensive set of stock prices that covers the National Banking Era. For the post-Civil War period their data come from The New York Times and The New York Herald. Goetzmann et al. (2001):

In 1815, the index was about evenly split between banks and insurance companies. By the 1850s however, banks, transportation firms (primarily canals and railroads) and insurance companies were all about equally common. By the end of the sample period, insurance, bank, mining and utility companies had nearly disappeared from the price lists... (p. 6) ${ }^{9}$

Figure 1 shows the overall number of stocks in the Goetzmann et al. stock index and the number of bank stocks. What is most striking is that after 1872 there are no bank stocks in their data set. This is the same result found by O'Sullivan. In 1885, 81 percent of the stocks traded on the New York Stock Exchange were railroad stocks, and there were no stocks listed in the finance, insurance and real estate sector, according to O'Sullivan (2007, p. 495), based on data from the Financial Review and the Manual of Statistics, a stock exchange handbook compiled by Manual of Statistics Company New York. Banks' stocks were sometimes listed as "Stocks More Active" by, say the New York Tribune during this period. But, taking a typical day, say May 1, 1891, the listing shows only the Western Bank, which traded twice, and the Continental Bank, which traded once on that day.

The volumes of bank shares traded in New York were also extremely low. For example, Figure 2 shows that the trading volume for bank stocks relative to the total trading volume around the Panic of 1893 was miniscule. ${ }^{10}$ Prior to the Civil War it did not matter if bank stocks traded, revealing information, because bank note discounts already revealed information (see Gorton 1996, 1999). But, in order for demand deposits to trade at par, it was necessary that information about bank risk not be revealed in the stock market. ${ }^{11}$

\section{Clearing House Bank Examinations}

With opaque banks, the clearing house had incentives to monitor and examine member banks because of the counterparty risk they faced in the clearing process. The Clearing House was empowered to

\footnotetext{
${ }^{9}$ The one and only "bank" stock that appears in 1883 and 1884 in Goetzmann is the Manhattan (s216) in the underlying data, which turns out to be the Manhattan Elevated based on our other sources, more of a transportation company. The New York Times calls it "Manhattan", while the Chronicle uses "Manhattan Elevated". The Manhattan price in the Goetzmann et al. (2001) data is $\sim 50$ for $1883 / 84$, which matches the Manhattan Elevated price in the Chronicle, while the Manhattan bank quotes were 150 .

${ }^{10}$ Results are similar for the panics of 1873 and 1907.

${ }^{11}$ Also, the National Bank Act in 1864 established double liability for bank stock. State chartered banks faced double liability in some states. See Marquis and Smith (1937) and Macey and Miller (1992). This may have made stocks less liquid, though there have been no studies of this in the U.S. Acheson, Hickson and Turner (2010) study $19^{\text {th }}$ century British banking and find that liability rules appear to not affect stock liquidity.
} 
examine member banks in the normal course of affairs. In the Clearing House Report (1873) this was stated as follows:

Any Bank in the city, worthy of public confidence, may become a regular member of the Clearing House Association, and the Banks which compose it are bound, in duty to themselves and to the public, to withhold the special support of this body from any who cannot submit to, or safely pass through the necessary examination which entitles them to credit. (p. 16).

This was made explicit in an amendment to the New York Clearing House Constitution, adopted on June 4, 1884:

The Clearing House Committee is also empowered, whenever it shall consider it for the interest of the Association, to examine any bank member of the Association, and to require from any member securities of such an amount and character as aid Committee may deem sufficient for the protection of the balances resulting from the exchanges of the Clearing House. (p. 7)

Bolles (1903):

One of the most important features of the association is the examination of every bank that applies for membership and watchfulness always exercised over it after its admission. Each member has a direct interest in every other, for it does not wish to run the risk of loss in giving credit to checks of an insolvent institution. So whenever there is any reason to doubt the solvency of one of their members, an examination is made under the direction of the governing committee of the clearing-house, and the truth is ascertained. Moreover, this examination is no sham, ignorant affair, but is likely to disclose the truth. If the business of a bank is in a bad way, the committee decides on a course of action that the bank must follow, or withdraw from the clearing-house. No bank wishes to withdraw, for to do so is set the seal of condemnation upon itself. Everyone knows what this means, that the institution is no longer worthy of credit. To withdraw under such circumstances would be essentially the same thing as to close its doors. (p. 379)

A description of the examination process is provided by Laughlin (1912) from a report on the method of bank examination in the Chicago and St. Louis clearing houses:

Without notice, the examiner of his own volition, and with his assistants, enters any bank or trust company and commences his examination. All information he asks for must be given him, and all books and papers placed before him as in the case of a national or state bank examination. When the examination is completed, he makes duplicate reports, stating all the essential facts obtained in his investigation-whether 
the institution has the required cash on hand, the amounts of its past due paper, the amount of its bad debts, if any, the amount due by the directors as payers, endorsers or as guarantors, and the amount due by corporations in which they are interested, the value of bonds carried and whether they are carried at a sum in excess of the market value, whether the amount shown as capital, surplus and undivided profits is represented not by bad, but by good assets; in other words, whether the published statements are true, and finally, a complete statement of the bank's condition is set out, with any suggestion which, in his judgment, sound banking requires him to make. ( $p$. 178)

If the bank does not comply with the recommendations of the report, then the clearing house can suspend or expel that bank.

It is important to note that the results of bank examinations were not made public. ${ }^{12}$ Bolles (1903, p. 379): "The extent of the supervision exercised by this association over its members the public will never know, because it is best that much of it remain secret. The banks thus associated learn more about one another than they ever would if acting entirely alone, and examinations are made, and warnings given, of which the public has no knowledge. The direct interest that every bank has in knowing the true condition of every other member is one of the great merits of the system."

Smith (1908) described the government bank examinations during this period as "defective" relative to clearing house examinations.

The examiners appointed by the Government and the various states, while carrying on their work as best they can, have to labor under difficulties which can be eliminated by this new method (i.e., special examiners appointed by clearing houses), and they cannot make as thorough an examination as the clearing-house examiners....Excessive loans to a firm that is borrowing from several banks, both national and state, can be discovered much better by the clearing house examiner, because he knows the relations of a borrower with the other banks. Each bank might be loaning to this firm what would be safe if he borrowed nowhere else, and in case of trouble all would lose. Clearing-House Examinations, Gordon C. Smith, Assistant Examiner for the Minneapolis Clearing House Association, Banker's Magazine, Volume 76, pages $177-78 .{ }^{13}$

\section{Special Bank Examinations during Normal Times}

An example of a special examination during normal times occurred in December 1871. In the Clearing House Minutes there is the following entry:

\footnotetext{
${ }^{12}$ This is also true today. The results of bank examinations in the U.S. are kept confidential.

${ }^{13}$ Throughout, references to Minutes refer to the Clearing House Minutes in the New York Clearing House Association archives.
} 
The National Bank of the Commonwealth having been drawn upon very heavily by its depositors in consequence of unfavorable rumors in circulation in regard to its condition and fearing a further run upon it -- as many of the Clearing House Committee as could be immediately summoned, and the Chairman of the Clearing House met at the Bank and made an examination of its condition, the result of which was the publication in the city papers of the following morning, of this notice. Clearing House Committee Minutes, December 14, 1871, March 11, 1854-December 10, 1894, Vol. 1.1 (no pagination). ${ }^{14}$

Another example is that of the Tradesmen's National Bank in November 1881.

Owing to unfavorable rumors affecting the standing of the Tradesmen's National Bank, the Clearing House Committee met at that bank at three o'clock this day, for the purpose of making an examination of its condition.

... and finding its capital unimpaired gave the bank a certificate as follows:

The undersigned Clearing House Committee of the New York Clearing House Association have today examined the Tradesmen's National Bank of New York and find that bank entirely sound and its capital unimpaired.

This certificate was furnished to the public through the press, and at once allayed the excitement and distrust in the community. Clearing House Committee Minutes, entry for November 14, 1881 (no page numbers).

It is usually the case that the examining Clearing House Committee provides such a certificate to the bank that can be publicized. No details are provided. This example, of the Tradesmen's National Bank, is interesting for another reason. While the details of the examination were not made public those details might well be important. On November 19, 1881, there is this entry in the Clearing House Committee Minutes regarding the Tradesmen's National Bank, as follows:

The Committee find much that met their disapproval, and after examination was complete felt it their duty to plainly state to the officer[s] of the [Tradesmen's National Bank of New York] their opinion of the weak nature of many of its assets and securities, and the impropriety and imprudence of large loans to its officers, as well as on its own stock, and on investment in stocks of a speculative character, and to warn them that if a reform did not at once take place in the general management of the bank, disaster must eventually and surely result. Clearing House Committee Minutes, March 11, 1854December 10, 1894, Vol. 1.1 (no pagination).

\footnotetext{
${ }^{14}$ Throughout, references to Minutes refer to the Clearing House Minutes in the New York Clearing House Association archives.
} 
There are many examples like this in the New York Clearing House Association Minutes. ${ }^{15}$ In general, in addition to normal examinations, the Clearing House undertook these special examinations.

\section{E. The Clearing House Required Public Information Revelation}

While the clearing house did not reveal the details of its examinations of banks, and while bank stocks were illiquid and hence not informative, the clearing house did require some information to be made public. Gibbons (1859):

Each bank in the city of New York is required by law ${ }^{16}$ to publish "on the morning of every Tuesday, in a newspaper printed in the said city, a statement under oath of the President or Cashier, showing the average amount of loans and discounts, specie, deposits, and circulation, for the next preceding week." (p. 322).

It was only when the Clearing House records were brought to such perfection as to give the means of analysis and test beyond dispute that the positive integrity of these statements guaranteed to the public. (p. 325)

New York Clearing House Association (1903): Section 16 of the Clearing House Constitution requires that "every bank, a member of the Clearing House Association, shall furnish a weekly statement of its condition to the manager, for publication, showing the average amount of . . " Cannon (1910):

Each bank belonging to the New York Clearing-house Association is required to furnish to the manger weekly, for publication, a statement of its condition, showing the average amount of loans and discounts, specie, legal tender notes, circulation, and deposits. The capital and net profits are also given... (p. 158).

The New York Clearing House had reasonably timely information about the ongoing operations of its member banks to conduct day to day clearing activities. Specific examinations during non-panic periods aimed to uncover fraud, the potential for insolvency or to verify solvency and reinforce that conclusion publicly.

\section{The New York Clearing House Association during Panics}

\footnotetext{
${ }^{15}$ Other examples include: April 6, 1872, examination of the Tenth National Bank; April 26, 1873, investigation of the Gallatin National Bank; April 29, 1873, examination of the Continental National Bank; May 1, 1873, examination of the Manufacturers' and Merchants' Bank; Dec. 10, 1877, examination of the Ninth National Bank; Jan. 30, 1888, examination of the Grocers' Bank; Jan. 28, 1880, examination of the German American Bank. See Clearing House Committee Minutes, March 11, 1854-December 10, 1894, Vol. 1.1 (no pagination).

${ }^{16}$ Printed verbatim in the article, "Weekly City Bank Statements." New York Daily Times (1851-1857); Apr 18, 1853; pg. 8; reproduced in Appendix C.
} 
In this section we examine each step of the events during the suspension period, starting with the onset of a panic.

We identify a "bank panic" based on the decision of the New York Clearing House to issue clearing house loan certificates. The logic is that their information was better than ours is today, so if they decided to issue loan certificates there were bank runs or bank runs were thought to be imminent. Based on this criterion, we examine five panics: 1873, 1884, 1890, 1893 and 1907. In the Panics of 1884 and 1890 the issuance of loan certificates was, apparently, by itself enough to forestall runs, leaving 1873, 1893 and 1907 as the severe panics. We discuss this further below.

The start of a panic is chaotic and sometimes the events do not result in widespread runs. As we noted above, we define a "panic" as an event in which the clearing house authorizes the issuance of loan certificates. This is sometimes coincident with suspension, but a general suspension only happens in the most severe panics. In those instances, the currency premium on certified checks appears when serious runs spurred a general suspension of convertibility of deposits into currency. In all five panics during the National Banking Era there was the temporary suppression of bank-specific information, roughly coincident with the authorization of loan certificate issuance. We provide the details in this and future sections.

\section{A. The Suppression of Bank-Specific Information}

In every panic not only were loan certificates issued, but also bank-specific information was suppressed. New York State law specified that the Clearing House make public the balance sheet information of its members, but the publication was cut off by the Clearing House to prevent weak members from facing runs. In addition, by reducing the likelihood of runs on banks that maybe perceived as weak, the New York Clearing House generally benefited because it then reduced the amount of loans that it would likely have to issue to support those banks if available information enabled depositors to identify them. The logic of cutting off bank-specific information was that upon issuance of loan certificates, the member banks essentially combined into a single legal entity. Furthermore, weak banks were protected because they could not be identified. So, the banking system would not unravel sequentially with the weakest bank being run on, and then the next weakest, and so on.

Curtis (1897, p. 260), with reference to the Panic of 1873 reports that: "No weekly Clearing House statement of the condition of each bank was made from Sept. $22 \mathrm{~d}$ to Dec. $8^{\text {th }}$, as it was deemed inadvisable to call attention to the weak condition of any bank and so precipitate a run on it." And, the New York Times, October 6, 1873, p. 2: "The Bank Clearing-house has ordered the discontinuance of the Weekly Bank Averages until the return to Greenback payment. It is deemed proper and advisable, while the hybrid expedient of Clearing-house Certificates for settling their daily clearance is needful to be continued, to attempt Weekly Averages in the usual way. The Banks are now acting as a single corporation..." 
In each panic, it was announced that this cut-off of information would occur. For example, Sprague (1910): “ . . . but these [weekly clearing-house] statements for the individual banks were discontinued during the crisis of 1873 ..." (p. 16). And, on Saturday, May 24, 1884 Chairman Tappan of the Clearinghouse Loan Committee announced the halting of the detailed weekly bank statement.

"The issue of loan certificates by the Clearing-house Association has so changed the relations of the banks to each other that the publication of the statement in detail would give an incorrect impression as to the actual condition of the banks." (New York Times, "Not a Good Bank Showing"; May 25, 1884; page 3).

The suppression of individual bank information lasted only one week in 1884. Further, the release of individual bank information on June 7, 1884 showed that Metropolitan National Bank had net deposits of $\$ 1.44$ million in contrast to its net deposits of $\$ 8.42$ million on May 10, 1884 (data taken from the Weekly Statements, Commercial and Financial Chronicle Bankers Gazette). The banking crisis in 1884 was focused on Metropolitan National Bank, which made it different from the more general and severe crises. See Gorton and Tallman (2015).

New York Clearing House Association Minutes, November 20, 1890, 2:00 pm: The Association voted to "discontinue the publication of the details of weekly reports." Similar instances took place in 1893 and 1907 , and the release of individual bank information was among the last things to be restored.

\section{B. Issuing Loan Certificates and the Change in the Organizational Form of the Clearing House}

The issuance of loan certificates was authorized by the Clearing House when widespread runs had already happened or were expected to occur. ${ }^{17}$ The logic of loan certificates was that they could economize on the use of cash among the banks in the clearing process. Curtis (1898, p. 253): "During the financial storm the . . bank will pay its balance by means of loan certificates. . " Loan certificates were issued subject to the approval of the Clearing House Loan Committee and subject to approved collateral with at least a 25 percent haircut on the fair market value of the collateral. The exact phrasing in the New York Clearing House resolution stated that the clearing house loan issues "shall not exceed 75 percent of the market value of the collateral" put forward. The haircut amounts varied based on the form of collateral provided as well as the amount (and frequency) of clearing house loan certificates requested. ${ }^{18}$ The New York Clearing House would often request substitute collateral for clearing house

\footnotetext{
${ }^{17}$ Clearing house loan certificates in the form we discuss were first issued in 1860 -- see Swanson (1908a,b). Redlich (1947) discusses the issuance of "Metropolitan certificates" in 1857 as a comparable liquidity vehicle, but the nature of the liability is sufficiently different to warrant a separate denotation. After the initial issuance in 1860, clearing house loan certificates were again issued in 1861, 1863, and 1864---1863 and 1864 are apparently not considered important-see Sprague (1910 page 46, footnote b). They were not issued again until the Panic of 1873. Cannon (1910a) provides more detail on loan certificates. Moen and Tallman (2015) presents the distribution of clearing house loan certificates among several borrowing banks in New York City for each of the panics from 1873 to 1907.

${ }^{18}$ Observations made from data set for the Panic of 1907 that has collateral values assessed.
} 
loan certificates if the initial collateral was perceived as insufficient, or if that collateral was maturing. We cannot rule out the possibility that the financial condition of the borrower was also relevant.

The authorization of the issuance of loan certificates was public and this, in itself, was viewed as a positive informational event. In the New York Times September 20, 1873, it was announced that the New York Clearing House was to issue $\$ 10$ million in clearing house loan certificates. In a sequence of articles in newspapers in 1893, the public was made aware of the total volume of clearing house loan certificates borrowed by the New York Clearing House banks during the panic. This was also the case in 1873 and 1907; the amounts borrowed by individual member banks were not made public.

Clearing house loan certificates were liabilities of the individual borrowing banks, but their repayment was effectively guaranteed by the clearing house membership jointly. ${ }^{19}$ Because the clearing house loan certificates were ultimately liabilities of the membership jointly their issuance signaled that the clearing members were binding themselves into a single institution. This was a remarkable process, of turning individual privately-owned banks into a single large bank. This is discussed by Timberlake (1984), Gorton (1988b), Gorton and Mullineaux (1987). Gorton and Huang (2006) provide a theoretical explanation of the incentive-compatibility of this transformation.

The Clearing House Special Committee of Five, June 16, 1884 (Clearing House Committee Minutes, 18781885, p. 158) stated:

Resolved: That the experiences of the associated banks in the New York Clearing House during the recent panic, having again shown that every member of the Association, in a time of general and serious financial disturbance, is involuntarily compelled to make common cause with every other member in the risk attending any practical expedient for general relief, or any effective combination for the public good: it is therefore proper and necessary to enquire whether the methods of business, as conducted by the several members of the Association, are uniform and correct in their operation with the public and equitable to all banks which are thus bound together in the Clearing House.

To issue clearing house loan certificates, the membership of the clearing house had to vote, essentially voting on whether the crisis was significant enough to warrant their use. For example, The New York Times reported on May 15, 1884 that: "A special meeting of the Clearinghouse Association began at 1:30 $\mathrm{pm}$. After meeting for more than an hour, the members unanimously adopted a resolution to issue loan certificates. This action brought a 'perceptible feeling of relief' to Wall Street." (New York Times, "On the Verge of a Panic"; May 15, 1884; page 1.)

\footnotetext{
${ }^{19}$ Losses on clearing house loan certificates would be paid through assessments on all surviving clearing house member banks in proportion to their capital and surplus relative to the total capital and surplus of the membership.
} 
Similarly, in 1890: "The NY Clearing House 'recognized the critical situation' on the afternoon of Tuesday, November 11, and authorized a resolution to issue loan certificates after the Bank of North America (a clearing house member) was short $\$ 900,000$ at the clearing house because of large advances made to Decker Howell, a brokerage firm that suspended earlier in the day. In total, three firms failed and three banks were unable to meet their clearinghouse obligations. (Commercial \& Financial Chronicle, November 15, 1890, page 667. Also see New York Times, "Firms Fail, Banks Shaken", November 12, 1890, page 1).

Consistent with the information blackout that we discuss further below, the distribution of loan certificate issuance among banks was kept secret in the most severe crises. For example, "While the Clearing House Committee did not meet, the "Law" committee issued "over a million" of loan certificates. Some of the larger banks (on occasion) had a tacit understanding that they would apply for loan certificates, even though they did not need them, in order to "remove the suspicion that there was any confession of weakness in asking for them" (New York Times, Nov. 18, 1890, p. 1). And, the next day the Times reported "The fact remains that nearly every bank is very sensitive about it and that the members of the Clearing House Association consider themselves honor bound not to mention the name of any bank that may thus have sought to protect itself against troubles" (New York Times, Nov. 19, 1890, p. 5). Unfortunately, such behavior was not entirely consistent because the New York Times reports on November 13, 1890 that a syndicate of banks extended loans to the Bank of North America, which then borrowed $\$ 900,000$ in clearing house loan certificates to repay those loans. The article also reveals the identity of Mechanics and Traders Bank as a borrower of clearing house loan certificates. But 1890 was considered a well-managed panic (See Sprague (1910) and Wicker (2000)).

Cannon (1910a, p. 83) writes that while weak banks may need clearing house loan certificates and strong banks not, still the strong banks also take them out. Moen and Tallman (2015) however could not verify the accuracy of those statements mainly because data are insufficient to indicate the liquidity requirements of the borrowing banks. Cannon's intimation could be correct, but Moen and Tallman found Cannon's argument about universal borrowing by clearing house member banks during panics to be incorrect.

In one case where a member (Chemical National) refused to accept clearing house loan certificates, it was suspended from New York Clearing House membership for three months. Cannon also later notes that:

Attempts on the part of the business community were made in vain to discover what banks had taken out certificates, but such information was very wisely withheld. For more than two months [during the panic of 1873], covering the worst period of the panic, no weekly statements of their condition were made to (by] the clearing-house banks, the object being to prevent general knowledge of the weak condition of some of the members, which, if disclosed, would invite runs upon them. (p. 90-91) 
As long as the loan certificates are outstanding, there was an interest charge to the banks that initially took them out from the New York Clearing House. In New York, the interest rate on loan certificates was 7 percent in 1873, 6 percent in 1884, 6.25 for thirty days; 6 percent in 1893, and 6 percent in 1907. See Curtis (1898, p. 255). Curtis (1898, p. 255): "Bearing a substantial rate of interest, a policy of speedy retirement was of course followed by the banks for whom they were issued. Self-interest dictated a short term of existence for the certificates, which have seldom been outstanding for more than four or five months at a time." The interest rates on clearing house loan certificates were about the same as the market rates for commercial paper, but the haircut on collateral can be considered as part of the cost. The collateral gets a bank up to 75 percent of the collateral value in terms of liquidity. Then, an interest rate charge of 6 percent on $\$ 75$ generates a cash outflow that will be covered by the interest on the $\$ 100$ collateral of 4.5 percent. $^{20}$

Figure 3 shows the maximum amounts of loan certificates outstanding during each suspension period and the duration for which the certificates were outstanding. For scaling purposes, we take these amounts relative to the average reserve holdings for the previous two years for the aggregate of New York Clearing House member banks. Three notable features distinguish the severe panics $(1873,1893$ and 1907) from the incipient panics (1884 and 1890). First, the duration of outstanding clearing house loan certificates is much longer, nearly twice the duration of the other two (the extended duration of 1884 reflects the outstanding balance of Metropolitan National Bank, which required nearly two years to settle). Second, and related to the first point, the peak of the outstanding balances of clearing house loan certificates in 1884 and 1890 is reached and then there is a relatively steady decline in the outstanding balances, whereas there is a longer duration of the maximum outstanding for clearing house loan certificates for the more severe panics. Third, there appears to be an association between the imposition of suspension of convertibility and the duration of clearing house loan certificate issues. In 1893, the issues of clearing house loan certificates spikes upward after suspension, extending and apparently expanding the duration of clearing house loan certificates.

Figures $4(\mathrm{~A}, \mathrm{~B}$, and $\mathrm{C})$ and 5 ( $\mathrm{A}$ and $\mathrm{B}$ ) show the certificates outstanding as well as the reserve surplus. Except for the Panic of 1890, there is a clear pattern. Loan certificates are issued when the reserve surplus declines. So the reserve deficit and loan certificates outstanding are mirror opposites of each other. As reserves decline due to runs, the clearing house issues loan certificates to economize on cash. The figures dramatically show the purpose of loan certificates.

In a report to the New York Clearing House following the Panic of 1907 (Special report to the Clearing House Committee, undated, no page numbers, New York Clearing House Archives), there is a table entitled "Division of Collateral Originally Deposited Against Clearing House Loan Certificates." The table

${ }^{20}$ Friday, May 16, 1884. A report circulated that the Clearinghouse Loan Committee decided to lend money against Government bonds at par, instead of applying the customary 25\% haircut. (New York Times, "The Ebb of the Panic"; May 17, 1884; page 1) 
distinguishes between only two categories of collateral - Bills Receivable and Securities. For the aggregate amount of clearing house loan certificates issued (\$101 million), bills receivable provided $\$ 107.6$ million of the collateral and securities comprised $\$ 44.1$ million of the collateral. The total amount of collateral originally offered was $\$ 151.7$ million indicating that the average haircut on collateral value was slightly less than 35 percent.

Additional collateral could be called for if the Clearing House was concerned about a particular member. For example: "The Clearing-house committee is also empowered, whenever it shall consider it for the interest of the association, to examine any bank member of the association, and to require from any member securities of such an amount and character as said committee may deem sufficient for the protection of the balances resulting from the exchanges at the Clearing-house" (New York Times, "The Storm Not Yet Spent"; May 16, 1884; page 1).

Alexander Gilbert, President of the Clearing House Association, said in an interview "that the association had resorted to the issue of loan certificates on nine different occasions, the total certificates issued amounting to $\$ 260,000,000$. Seventy-two per cent of the collateral was commercial paper and only twenty-eight per cent other securities. Not a dollar has been lost in connection with these transactions." (Editorial, “A Menace to American Prosperity," The Bankers' Magazine LXXVI (April, 1908), 479-480).

\section{Suspension of Convertibility}

Suspension of convertibility means that banks refuse to honor their debt contracts, that is, they refuse to exchange currency for demand deposits. During the National Banking Era panics, suspension of convertibility was never organized and announced by the clearing house. ${ }^{21}$ It was also never legal, but this was not enforced (see Gorton (2012).)

As we will discuss further below, the relationship between the dates of suspension of convertibility and the issue of clearing house loan certificates varies across the five panics. In two cases (1873 and 1907) the two events are basically coincident. In the remaining three cases issuance starts before suspension and, as mentioned above, in two of those cases (1884 and 1890) issuance seems to have prevented the need for suspension.

Once one or more large banks suspend convertibility, all the other banks are forced to suspend convertibility as well because they are not receiving cash deposits. This was especially an issue because reserves were distributed unevenly (except for the Panic of 1873 when reserves were pooled), as noted by the 1873 Report of the clearing house. Sprague (1910) writes that:

The real reason for suspension [in the Panic of 1893] was that which was pointed out in the report of the clearing-house committee of 1873 . The drain [on reserves] had not fallen equally upon the banks. We have no means of knowing the exact positions of the

\footnotetext{
${ }^{21}$ Suspension was announced in New York City in the Panic of 1857, but that was a suspension of bank currency redemption for specie (gold).
} 
few large banks which held the bulk of bankers' deposits at this time, but there can be no doubt that they must have suffered a far more serious loss of reserve than that of the banks taken as a whole. (p. 181)

Sprague (1910) writes that by the Panic of 1907 “ . . the tradition seems to have become established among New York banks that the issue of clearing-house loan certificates and the suspension of cash payments are virtually one and the same thing" (p. 171).

\section{Special Bank Examinations and Proactive Lending during Suspension Periods}

The bank examination procedures during normal times laid the groundwork for special examinations during suspension periods. During suspension, while bank-specific information was cut-off, the Clearing House did engage in some highly public special bank examinations. They examined some banks that were subject to rumors and they jointly aided and bailed out some other members.

In the case of a special examination during suspension, the results of the examination were only publicized with a certificate of health issued by the Clearing House Committee. The certificate gave no details of the examination, but just stated that the bank was solvent. This occurred even if privately the Clearing House Committee had reservations about the bank. In fact, the detailed results of clearing house examinations were never made public, even in normal times, although active lending to a distressed member bank (effectively bailouts) was public.

In this section we examine the special examinations during periods of suspension.

\section{A. Bank Examinations during Suspension Periods}

During suspension periods the only information coming from the Clearing House was, first of all, the release and publication of the aggregate balance sheet of the Clearing House, and secondly, the results of special examinations of member banks, often at their request. After these special examinations the clearing house did not reveal very much information, only that there had been an examination made by the Clearing House and that the bank was certifiably sound. In fact, the Clearing House supplied such a certificate to the bank that had been examined.

Table 1 lists the special bank examinations carried out by the NY Clearing House during each of the five panics, even though there was no suspension in 1884 and 1890. However, there were not a lot of special examinations. There were a total of thirteen, including three state banks in 1907, an average of less than three per panic. Of the thirteen, five were not Clearing House members.

During the Panic of 1873, the National Bank of Commonwealth, a New York Clearing House member bank, received assistance from other banks and was advised not to suspend convertibility, but in the end it did suspend (New York Times, September 21, 1873, p. 1). A government bank examiner and a receiver 
[an official who could take charge of the bank if deemed necessary] examined the bank. No official statement was released, but the receiver stated that depositors were very likely to be paid in full (New York Times, September 24, 1873). In early October, the Director of the bank refused to accept the examination report of the receiver, saying that it was incorrect. He pleaded with the Clearing House to examine the bank. The Clearing House did appoint a committee on October 7 (New York Times, October 8,1873 , p. 5). The Clearing House issued a statement: "Resolved. That a special committee of five be appointed, which shall with the President and Directors of the National Bank of Commonwealth, make an examination into its affairs and report at a future meeting of the Association" (Clearing House Committee Minutes, Oct. 1, 1873, March 11, 1854-December 10, 1894, Vol. 1.1 (no pagination)).

There is no evidence that the special committee issued a report about the bank and the National Bank of Commonwealth did fail. Sprague (1910, p. 43) reports that there was, however, no loss to creditors. Apparently, the failure was not viewed as important information. Sprague (p. 43) says: "[National Bank of Commonwealth's] solvency had been long in question, and its business was of no small proportions, with loans in question in the neighborhood of $\$ 2,000,000$. Its failure, therefore, was not one of the serious factors in the situation."

During the Panic of 1873 the Clearing House also examined non-members. On Oct. 1, 1873 the Clearing House Minutes say that:

The Clearing House Committee have made a thorough examination of three Banks during the year, suggested by unfavorable reports affecting their credit, in two cases finding the rumors unfounded and by a publication of a certificate signed by them to that effect, saving them from serious loss. Clearing House Committee Minutes, March 11, 1854-December 10, 1894, Vol. 1.1 (no pagination).

Sprague (1910, p. 151) says that the three banks were state banks and were not Clearing House members.

In one case during the Panic of 1893, a bank was examined and then liquidated. Seaboard National Bank, a Clearing House member, was the clearing agent for the National Bank of Deposit. The National Bank of Deposit had a significant reduction in its deposits, and its solvency was in question. Seaboard National refused to continue acting as clearing agent for the bank: "Notice of this intention was given yesterday afternoon by the Seaboard and was followed by a visit by the Clearing House Committee, and inspection of its assets and a recommendation that the bank go into liquidation." A statement by the Clearing House issued at the Bank of Deposit at 9 p.m. after two hours of inspection: "The Clearing House Committee examined the assets of this bank this afternoon and were of the unanimous opinion that the bank should go into liquidation. The committee expressed the opinion that in all probability the depositors would be paid in full“ (See New York Times, May 22 and 23, 1893, p. 1).

Three large Clearing House members were examined during the Panic of 1907. One was the Mercantile National Bank. According to the New York Times (October 17, 18, 1907, p. 1): 
An examination of the Mercantile Bank was made after the close of business last night [Oct 17] by a selected committee of the Clearing House Association. "It was virtually decided that if the examination proved the bank to be in sound condition, the Clearing House would stand by the Mercantile National and see it through any troubles which might follow the events of the last few days." At midnight, the Chairman of the Clearing House issued a statement saying that "the examination results show the bank to be perfectly solvent and be able to meet all its indebtedness. The capital of $\$ 3,000,000$ is intact and with a large surplus." "The bank will reopen for usual business the next morning."

On October 18, (reported by the New York Times October 19, 1907, p. 1): "The Clearing House Committee met yesterday morning and formally voted to extend to the Mercantile any assistance which it may need ... the subscriptions received to the fund for the help of the Mercantile included subscriptions of $\$ 200000$ from nine individual banks. This made a fund of $\$ 1,800,000$." [The loans were actually clearing house loans, which were like emergency loans from the New York Clearing House (as opposed to clearing house loan certificates) .]

Then, on October 19, 1907 the Clearing House voted to extend "\$900,000---in addition to the amount already advanced" to the Mercantile National Bank. Clearing House Committee Minutes, October 17, 1907, p. 337 (hand written).

"As a prerequisite to the extension of this aid the Clearing House Committee asked for the resignation of all the directors of the bank ... The Clearing House Committee felt that the new President of the bank should have a free hand in building up the organization. It was with this object in mind that the Directors all requested to resign. Among the present Directors there are some gentlemen eminently qualified to serve as bank Directors, but the Clearing House Committee feels that the retention of the Board of Directors which has been responsible for the position in which the bank was placed would not serve to restore confidence in the situation" (New York Times, October 19, 1907, p. 1).

With respect to the Mercantile Bank, Monday [New York Times October 22, 1907, p. 1]: "The number of clearing House member banks subscribed to the assistance fund increased from 9 to 25, with the new banks each contributing $\$ 400,000$, making a total of $\$ 10$ million. There are 53 members of the Clearing House, so just about half subscribed to the assistance fund." Wicker (2000, p 90) says that the Mercantile National Bank received $\$ 1.9$ million from the assistance fund of the Clearing House.

The New York Times reported on October 19, 1907 that: "The knowledge that the Clearing House stepped in to guarantee the solvency of the bank proved a great relief to the financial community" ( $p$. 1). The issuance of clearing house loan certificates was delayed until October 26, 1907, but the extension of loans to Mercantile National Bank indicates that the New York Clearing House was intent on addressing the problem at hand, which was deemed concentrated among the Heinze-Morse-Thomas banks.

\section{B. Examinations during Financial Distress Periods without Suspensions: 1884, 1890}


The Panic of 1884 did not involve a suspension of convertibility. The panic began with the closure of the Marine National Bank, which was involved with the failed brokerage house of Grant and Ward. From an examination of the Marine National Bank, the New York Clearing House decided not to aid the bank and explained (publicly) that the assets of the bank were insufficient for it to reopen.

The next point of focus was the Metropolitan National Bank, which was forced to close temporarily on May 14, 1884. It was examined by New York Clearing House examiners, "a committee of examination" (Commercial and Financial Chronicle, December 6 1884, page 634) and was deemed to have sufficient assets in good condition to warrant aid in the form of clearing house loan certificates. This case is discussed in the next subsection on prompt liquidity provision.

The New York Clearing House was acutely aware that the Metropolitan National Bank was in trouble:

The Chairman [of the Clearing House Committee] stated that he had called the meeting to consider the situation of the Metropolitan National Bank, as many rumors respecting that bank had been in circulation during the day.

After an expression of opinion by all present, it was deemed best to cause an examination of the bank to be made immediately. Mr. [ William] Nash [one of five members of the Clearing House Executive Committee] states that he had in readiness a corps of examiners attached to his bank . . Clearing House Committee Minutes, March 11, 1854-December 10, 1894, Vol. 1.1 (hand written minutes, p. 337).

The Committee appointed to examine the Metropolitan National Bank reported as follows: "The Capital of the Bank was found to be unimpaired . . . it was Resolved to extend aid to the bank to pay its debit balance in the sum of $\$ 400,000$." Clearing House Committee Minutes, March 11, 1854-December 10, 1894, Vol. 1.1 (hand written minutes, p. 338).

In 1890, as shown in Table 1, three clearing house members were examined. On Tuesday, Nov. 11, 1890, three banks required immediate assistance from the New York Clearing House. "At an early morning meeting, the presidents of nine of the Clearing House banks were informed of the difficulties facing the Bank of North America. . The nine bank presidents each "contribute[d] $\$ 100,000$ to the Bank of North America with securities as collateral, which it used to make its exchanges later that day so that the bank's "'embarrassment' was only an 'exceedingly temporary affair' " (New York Times, Nov. 12, 1890, p. 1).

On Wednesday, November 12,1890 , the Clearing House issued $\$ 1,495,000$ of loan certificates: $\$ 900,000$ to the Bank of North America, $\$ 500,000$ to the Mechanics and Traders' National Bank, and $\$ 95,000$ to the North River State Bank (New York Times, November 13, p. 1). These were the three troubled banks. Two days later, on November 14, 1890, the Clearing House committee completed its investigation of the Bank of North America, issuing a report stating that the bank's "capital is intact, it has a large surplus, and its means are ample to meet all its obligations" (New York Times, November 15, 1890, p. 8). The 
financial problems at these banks were apparent and direct aid from the New York Clearing House with the explicit publication of the loan amounts was taken as a positive step.

On Nov. 15, 1890, the Clearing House Committee finished investigating the Mechanics \& Traders' National Bank, and issued a report again stating that the bank's "capital is intact, it has a large surplus, and its means are ample to meet all its obligations" (New York Times, Nov 16, p. 2).

The North River Bank was closed by New York State Superintendent of Banking on November $12^{\text {th }}$ and did not reopen; the other banks did not close during this crisis.

\section{Special Examinations by Government Regulatory Authorities}

Table 2 lists the examinations of government bank examiners during each panic. There were a total of ten.

Among the government examinations, the most informative ones took place in 1884 and 1890, the two financial crises without suspensions. The examination of the Marine National Bank by the national bank examiner began on May 6, 1884. The results of the examination concurred with the one by the New York Clearing House, and the bank was permanently closed on May 14, 1884. Further, supplementary regulatory agency action allayed the fear of widespread bank insolvency. The Second National Bank, which suffered the defalcation of $\$ 3$ million by its president (promptly replaced by the father of the president), was given a positive review on May 15. The Commercial and Financial Chronicle (December 6,1884 , page 635) describes how the Comptroller of the Currency, on May 14, recognized the imminent financial distress and sent several reliable examiners to New York City to support the national bank examiner stationed in New York. The national bank examiner played a part in approving the plans to issue clearing house loan certificates and to reopen the Metropolitan National Bank. This point is conveyed in the description of the national bank examination of Metropolitan National Bank in Table 2. On Monday, May 26, 1884, the Comptroller of the Currency stated that the national bank examiner was "keeping an eye on the situation, and had reported to him that the national banks were all in good condition as far as he knew" (New York Times, "Condition of the New York Banks"; May 27, 1884; page 1).

\section{Clearing House Actions of Prompt Liquidity Provision}

Some instances of possible depositor losses being covered by the New York Clearing House (bailouts) were discussed above in subsection A. Here we discuss the remaining cases that hint at explicit aid as opposed to temporary loans with repayment anticipated.

During the Panic of 1884, the Metropolitan National Bank, a New York Clearing House member, was in trouble. On May 14, 1884, the Metropolitan National Bank owed \$575,000 to the Clearing House which it was unable to pay. "The Clearing-house Committee have [sic] made an examination of the Metropolitan National Bank and find the assets justify them in recommending to the Loan Committee to 
advance the amount required to enable the bank to immediately resume business." 22 The New York Times estimated that the advance was $\$ 3,000,000$. Mr. William Dowd, a member of the Clearing House Investigating Committee and president of the Bank of North America, confirmed that the Metropolitan would reopen the next day. He stated that "Every bank that is sound will be assisted if it needs help," but that he did not think there would be any other failures. ${ }^{23}$ The bank did not fail during the period of financial distress. However, the run by depositors of Metropolitan National Bank did not diminish. From May 17 to May 31, the net deposits at Metropolitan National went from \$7.4 million to \$1.7 million. By June 21 , net deposits fell to $\$ 1.2$ million. The bank voluntarily liquidated November 18 , 1884.

Wicker and Sprague report that Metropolitan National had 2/3 of its deposits as correspondent balances. This large role as a correspondent bank suggests that other banks withdrew the majority of the Metropolitan National Bank deposits. What was most notable is that there was apparently no evidence of a contagion effect. We note that the Metropolitan National Bank was able to weather the run with the aid of clearing house loan certificates in an amount approximately as large as their net deposit liabilities at the beginning of the financial distress ( $\$ 7.54$ million was its maximum indebtedness).

During the Panic of 1907, the Clearing House also examined the National Bank of North America and the New Amsterdam National Bank, concluding that the capital of the National Bank of North America was "unimpaired," and that the New Amsterdam National Bank "can, with proper management, be carried through safely" Clearing House Committee Minutes, October 17, 1907 (hand written Minutes, p. 339). Later, "The Committee voted to aid the New Amsterdam National Bank in the sum of $\$ 335,000$---to be subscribed by individual banks, and in addition to the sum already advanced to the bank" Clearing House Committee Minutes, October 17, 1907 (hand written Minutes, p. 342).

In the Panic of 1907, the New Amsterdam National Bank was assisted by the clearing house. According to the New York Times, October 21, 1907, p. 1, the Clearing House issued a statement that:

A Committee of the Clearing House has examined the several banks of the association [National Bank of North America and the New Amsterdam National Bank] that have been under criticism, and, find them solvent, the Clearing House Committee has decided to render them such assistance to meet their deposits as the committee may think necessary.

While no announcement of the course followed was made, it is believed that individual banks in the clearing house pledged themselves to provide specific amounts of money

\footnotetext{
${ }^{22}$ New York Clearing House Minutes May 14, 1884, from the Archives of the New York Clearing House.

${ }^{23}$ New York Times, May 15, 1884, p. 1. Marine National Bank was closed and after an examination indicated malfeasance and insufficient assets of quality, the New York Clearing House made clear it had no intention of aiding that bank.
} 
for use as needed, receiving for their advances collateral from the banks helped, as was done in the Mercantile' s case. (p. 1)

On October 28, 1907, the New York Times reported that the "President of the New Amsterdam issues an announcement to depositors: '...The bank has been put through a vigorous and extraordinary examination by the $\mathrm{NYCH}$, and has been found solvent, with capital unimpaired. This examination now places us in a singularly strong position' "(p. 3). The bank was saved until the end of January. On January 29, 1908 the New York Times reported that the New Amsterdam National Bank decided to close, and was put in hands of the receiver. Resumption of convertibility occurred January 4, 1908 so the bank made it through the crisis (Wicker, 2000, p. 9).

The National Bank of North America also received assistance. On October 20, 1907 (p. 1) the New York Times reported that: "Statement by the Clearing House: A Committee of the Clearing House has examined the several banks of the association [National Bank of North America and the New Amsterdam National Bank] that have been under criticism, and, find them solvent, the Clearing House Committee has decided to render them such assistance to meet their deposits as the committee may think necessary. The New York Times then comments that: "While no announcement of the course followed was made, it is believed that individual banks in the clearing house pledged themselves to provide specific amounts of money for use as needed, receiving for their advances collateral from the banks helped, as was done in the Mercantile's case. " (New York Times, October 21, 1907, p. 1)

Trust companies were not members of the New York Clearing House mainly for reasons associated with their business differences from banks. ${ }^{24}$ This fact - the non-membership of trust companies in the New York Clearing House -- was a main justification for why the New York Clearing House did not come to the aid of Knickerbocker Trust on Monday, October 21 at the request of the National Bank of Commerce. However, the Clearing House did financially assist trusts in other cases. Sprague and Wicker consider the denial of aid to Knickerbocker Trust an egregious error on the part of the New York Clearing House. If they are correct, J.P. Morgan committed the same error a day later.

According to the New York Times (October 22, 1907, p. 1), the Trust Company of America experienced a run. The amount withdrawn was $\$ 500,000$. A state bank examiner made an examination of all the loans of the Trust Company of America and found that no loans had been made to Mr. Charles Morse and that the loans to Mr. Charles Barney were only $\$ 175,000$ and in sound condition. ${ }^{25}$ Morgan and Co. agreed to lend $\$ 1$ million upon hearing the results of the examination. However, this did not stop the run, and the next day \$13 million was withdrawn (Wicker (2000. P. 92) and another \$9 million again on October

\footnotetext{
${ }^{24}$ From Tallman (2013, page 51): "Trusts competed effectively for retail deposits with national banks in New York City. Yet trusts were not considered part of the high-volume check-clearing part of the payments system, because deposits at trust companies did not turn over at rates similar to national banks. As a result, trust companies did not seek membership in the New York Clearing House when membership was offered in 1903."

${ }^{25}$ Charles W. Morse was described by O.M.W. Sprague (1910, page 258) "... Morse whose activities in the industrial and banking world had been of an extreme character, even when judged by American speculative standards."
} 
24, 1907 (New York Times (October 25, 1907, p. 1) The New York Times (October 24, 1907 page 1) reported that the U.S. Secretary of Treasury announced that: "As evidence of the Treasury's disposition, I have directed deposits in this city to the extent of \$25 million." This amount increased to \$35 million (Wicker (2000), p. 93, 99, Tallman and Moen 1990: 8). Most of this money was directed to assisting the trust companies which did not receive aid from the Clearing House Association. National City Bank and First National Bank loaned \$2.5 million and Trust companies jointly provided \$8.5 million. Hanover National, First National, National City and Morgan's Bank provide \$1.5 million. On November 2, 1907 "Another examination of the trust reveals position to be 'less pessimistic than expected'. Trust companies agree to jointly provide another \$15 million" (Wicker (2000), p. 97).

The runs on trust companies subsided November 4 after sufficient trust company resources ( $\$ 25$ millions) were allocated toward liquidity needs of those trust companies suffering depositor withdrawals. Still, without imposing a suspension of convertibility, New York City trust company deposits contracted sharply and never regained the size that rivalled the New York City national banks.

\section{The Panics of $\mathbf{1 8 8 4}$ and $\mathbf{1 8 9 0}$}

In the panics of 1884 and 1890 there was no suspension of convertibility. Wicker (2000) calls these episodes "incipient" panics. However, the New York Clearing House did stop publishing bank-specific information, but in 1884, they suppressed the information for only the week of May 24. Clearing house loan certificates were authorized and issued in each of these panics. As is clear in Figures 5A and 5B the reserve deficit (relative to required reserves) in 1884 and 1890 were brief and shallow. In both periods, the issuance of clearing house loan certificates aimed to assist specific institutions, rather than a general situation (Sprague (1910, p. 143). In this sense, these two instances of financial distress appear more akin to a localized bank run than a widespread banking panic. Still, the actions appear to have alleviated the need for a suspension of convertibility.

According to Sprague (1910, p. 108), the 1884 panic was mostly confined to New York. Philadelphia newspapers make no mention of problems there, for example, but Bluedorn and Park (2015) find evidence of a response by Pennsylvania state banks. Above, we discussed the problems of the Metropolitan National Bank during the Panic of 1884. The Annual Report of the Comptroller of the Currency $(1884$, p. 33-34):

After consultation with the officers and directors of the Metropolitan National Bank a committee of examination was appointed to visit the bank and ascertain if some plan could not be arranged to permit it to open again for business. The greater part of the securities of the bank were found to be of such a character that loan certificates could safely be issued upon them, and in this way the Metropolitan National was enabled to resume business on May 15 and settle its balances at the clearing house. The prompt action of members of the associated banks and the resumption of the Metropolitan National Bank greatly assisted in allaying excitement and staying the panic, and although confidence was not immediately restored ... there was no suspension ... and the issue 
of loan certificates was confined to the banks of New York City, which were soon enabled to collect their loans and make good their reserves.

It seems clear that in 1884 Metropolitan National Bank was important enough to the correspondent system that the New York Clearing House would aid it. What is somewhat surprising, however, is that Metropolitan National Bank lost such a large proportion of its deposits so quickly (dropping from \$7.4 million to $\$ 1.7$ million in the span of two weeks). Interior banks may have removed deposits from their correspondent bank in New York City (Metropolitan National), but likely moved those deposits to another New York City correspondent bank. There was no widespread and persistent draining of reserves from New York City banks. Bluedorn and Park (2015) argue ". . that bailouts of [systemically important banks] by the New York Clearing House likely short-circuited a full-scale banking panic" (p. 1)

In the case of 1890 , loan certificates were issued at an earlier point in the crisis, before there were many runs. Sprague (1910, p. 142-3) speculates that the loan certificates were issued promptly based on news about troubles in London. In the case of 1890, three clearing house members had problems: the North River Bank, the Bank of North America, and the Mechanics \& Traders Bank. These three received loan certificates. Sprague (p. 142): "The prompt action taken by the clearing-house authorities did much to prevent the spread of panic."

\section{Certified Checks and the Currency Premium}

While individual bank information was suppressed, a new market opened during the suspension period: the market for certified checks. Depositors' beliefs about the solvency of the New York Clearing House, essentially the solvency of the U.S. banking system, can be measured by the currency premium in terms of certified checks. There was a market for cash, which could be purchased using certified checks, but at a premium. The rise of a positive currency premium is due to the preference for cash over certified checks. In a crisis these are not perfect substitutes; there is an excess demand for cash. Beliefs about the solvency of the banking system are reflected in the currency premium (i.e. the excess demand for cash as a medium of exchange, due to hoarding). The currency premium reflects beliefs conditional on all of the Clearing House's actions: issuing loan certificates, special examinations of member and nonmembers, increases in the aggregate reserves of the Clearing House. In this Section we examine certified checks and the currency premium during panics.

\section{A. Certified Checks}

Certified checks were introduced and began trading during the Panic of 1873 . Certified checks were not "money" and so were not subject to the tax that been legislated in 1864 to effectively eliminate the issuance of private bank notes that predominated prior to the U.S. Civil War. This, however, was essentially a fiction. Figure 6 shows two examples of certified checks.

Sprague (1910) speaking of the Panic of 1873: 
.. the following momentous resolution was adopted [by the New York Clearing House]:

That all checks when certified by any bank shall first be stamped or written "Payable through the Clearing House."

The adoption of this resolution involved the partial suspension of cash payments by the banks. It did not signify that no money whatever would be paid out to depositors, but it placed the dwindling supply of currency more absolutely within the control of the clearing-house committee. (p. 54) . . The first and most immediate consequence of partial suspension by the New York banks was the appearance of a premium upon currency in terms of certified checks. (p. 56)

Timberlake (1984) explains what this meant in practice:

Another innovation during the panic of 1873 was the issue of irredeemable "certified" checks to stretch the reserve base. These checks did not have cash on deposit as the basis for their issue. They were simply a quasi-currency. To prevent anyone from cashing them and thereby reducing bank reserves, the clearinghouse policy committee adopted this resolution: "All checks when certified by any bank shall be first stamped or written 'Payable through the Clearing House' " (Sprague 1910, p. 54). This resolution put certified checks on a par with clearinghouse loan certificates. The banks accepted them as settlement media by common consent through their clearinghouse association, but did not have to redeem them with legal tender. (p. 5).

Sprague (1910) notes that the actions of the clearing houses in Boston, Philadelphia, Baltimore, Washington, New Orleans, Cincinnati and St. Louis to issue clearing house loan certificates as well as certified checks (Payable through the Clearing House) "were sanctioned" (p. 62-63). Also, see Cannon (1910, p. 91-97).

Certified checks stamped "Payable through the Clearing House" were handed out as cash during panics. See Andrew (1908) and Kniffin (1916). Clearing house member banks accepted certified checks as cash in the clearing process. This put every bank at risk to the possible failure of the certifying bank and created an incentive to monitor each other. But, the checks were not explicitly guaranteed. Certified checks were used as a form of hand-to-hand currency. The editorial, "The Central Bank Scheme," The Bankers' Magazine LVVVI (1908), p. 7-8 (January) put it this way:

The issue of 'clearing-house checks' has shown that here is a form of currency that may be used to great advantage in times of panic.... There is, perhaps, not much danger of loss to the holders of any of this form of currency, since the banks constituting the various clearinghouses will no doubt see to it that there is ample security for all the notes put out(p. 8). 


\section{B. The Currency Premium}

Figures 7A, B, and C show the currency premia for the panics of 1873, 1893 and 1907. Notably, the currency premia do not always monotonically decline in any of these panics. The premia reached a high of five percent in all three cases. The currency premia are highest at the beginning of a panic when it was not yet clear that the New York Clearing House actions would be effective or were going to be effective. In 1893, the currency premium arose following the suspension of convertibility, which took place August 3, nearly six weeks after the first issues of clearing house loan certificates. As a result, the currency premium was not as closely associated with the degree of uncertainty in financial markets in 1893 as in 1873 or $1907 .{ }^{26}$ We explore the relationship of the currency premium and the importation of gold during the crises of 1893 and 1907 further in the next section.

In the Panic of 1893, suspension occurred in early August, but the currency premium at least as reported by the press appeared later. The 1893 dates are probably off - the suspension of convertibility was in early August. Notably, the path for 1907 high for a long period of time and did not really go down until there was enough gold in the country (discussed subsequently) for the NYCH to rescind suspension. That pattern could indicate why the panic of 1907 led to the creation of the Fed. The situation was becoming beyond the control of the NYCH.

\section{The Change in Depositors' Beliefs during Suspension}

In this paper, we paper propose that depositors (both individual households and interior banks) must have changed their beliefs about the solvency of the banking system in order for them to choose to redeposit their funds in New York Clearing House banks after having previously removed them. The cut-off of bank-specific information focused attention on the solvency of the banking system, i.e., the New York Clearing House, rather than individual banks. This was consistent with the clearing house becoming a single legal entity via the issuance of loan certificates. Secondly, a new market opens in which the currency premium embedded expectations about the solvency of the clearing house. We first examine the timing of events that culminates in resumption of convertibility. Then we examine the changes that moved the currency premium to zero.

\section{A. Summary of the Timing of Crisis Events}

Table 3 summarizes the timing of events. The table presents an overview of the five panics during the U.S. National Banking Era. In Appendix A we provide the details of the sources for the information in Table 3. The table contains the important dates that are central to what follows. The columns in Table 3 are in chronological order for the severe panics. This is important as we will see further below.

\footnotetext{
${ }^{26}$ This difference may also reflect the distinct nature of the disturbance in 1893 . New York City was not the focus of the crisis in 1893, whereas it was the focus in 1873 and 1907.
} 
Columns 1-5 concern the start of the panic. Column one of the table shows the date which is often cited as the start date of the panic. Column 2 lists the date at which the New York Clearing House stopped publication of bank-specific information of the member banks. Column 3 shows the date when clearing house loan certificates were first issued. Column 4 shows the date of the suspension of convertibility. Column 5 shows the first date at which the currency premium on certified checks is positive. When the panic starts, columns 2 and 3 are the clearing house policy responses. The panic is ongoing as the currency premium indicates.

Importantly, in the severe panics of 1873,1893 and 1907, the first action of the clearing house is to suppress bank-specific information. Then clearing house loan certificates are issued, followed by suspension of convertibility. Finally, the currency premium becomes positive. In these panics, we observe a timing sequence that is for the most part consistent. Two things separate 1884 -- firstly, it was the only case in which only New York City issued clearing house loan certificates (no other city's clearing house did), and it was a panic in which the main concern was preventing runs on a few banks from affecting the financial system in general, and it was successful in avoiding an episode of currency hoarding.

The table shows that in all five events the clearing house stopped the publication of bank-specific information as the first action the clearing house takes. What the five events have in common is the suppression of bank-specific information and the issuance of loan certificates. The dates of loan certificate issuance are also notable, as the issuance depends on the information that the clearing house member banks have. The clearing house can see the panic coming. Clearing House loan certificates were issued two days prior to suspension in 1873 and one month prior in 1893; in 1907 suspension and the first issue of loan certificates were coincident. There was no suspension in 1884 and 1890, but loan certificates were issued in significant amounts. Still, even in 1884 and 1890 the New York Clearing House Association did not publish bank-specific information, though only for one week in 1884 . In the severe panics, the currency premium arises following a suspension of convertibility when there is also an issuance of loan certificates.

What about the ending of the crisis? Columns 6-10 are about the ending of the panic. Column 6 shows the date at which the currency premium becomes zero. The date of resumption of convertibility is in column 7. Column 8 shows the last date that clearing house loan certificates were issued. The date that clearing house members' bank-specific information is again published is in column 9. The final cancellation date of the loan certificates is in column 10.

With regard to the ending of panics, the sequence of events for the severe panics is also notable. The currency premium hit zero before resumption and before individual bank information starts being published again. In other words, the market price of systemic risk goes to zero before there is any return to normality. Market participants can see the light at the end of the tunnel, so to speak. These expectations are embedded in the currency premium. Individual bank information is only published again a month or two after convertibility is resumed. And, resumption of convertibility was never 
announced by the clearing house. The banks appear to ease into it, without any coverage in the press! See Appendix A.

After New York City, the next most important financial center was Philadelphia. Table 4 shows the same information for Philadelphia. There was no panic in Philadelphia in 1884 . The Philadelphia Clearing House Association also stopped the publication of individual bank-specific information and issued loan certificates in the other four panics. As in New York City, the currency premium becomes zero to signal the end of the suspension period. Resumption then occurs and only later was individual bank-specific information published again.

\section{B. The Importation of Gold}

Our hypothesis is that the New York Clearing House bank took actions to signal to their depositors that the banking system was solvent and liquid. The actions taken were fundamental to liquidity and solvency of the banking system and they were publicly known and verifiable. For the panics of 1893 and 1907 the evidence presented below describes the mechanism that allowed the New York Clearing House banks and other intermediaries to import gold from abroad. The mechanism relies on an existing institutional structure that enabled large, New York City national banks along with international gold arbitragers to contract for gold importation from financial centers overseas.

The observation of gold imports flowing into New York City was a key signal of solvency (and impending liquidity) that the New York Clearing House banks could convey to the public.

Laughlin $(1911,262)$ expresses a similar idea with a practical and operational motivation: "Here is the fatal deficiency of bank-note issues as a means of curing a panic. In 1907 the one thing needed was lawful money which could be used as reserves. We must face facts, and not be led away by theories. The New York banks got this lawful money in two ways: (I) by importing gold, and (2) by deposits from the treasury."

The Panic of 1873 took place before the United States returned to the gold standard so gold flows may play a part in the recovery from that crisis, but the role that gold plays in 1873 differs from the role gold plays in 1893 and 1907. Gold inflows in 1873 indicate increasing assets but not cash liquidity. We discuss the Panic of 1873 separately, after the discussions of 1893 and 1907.

Gold imports were important for bank depositors because the gold was coming into the banks in the United States signaling the confidence of foreign investors in the solvency of the New York Clearing House banks. Further, it was a response to the liquidity shortage, during which the New York Clearing House banks imposed restrictions on the convertibility of deposits into cash. For correspondent banks that had deposits in New York City banks, the gold imports were also an important factor to change their beliefs about the severity of the crisis. We show that both the gold imports and a net increase in deposits from interior banks were important conditions for the New York Clearing House banks before they chose to restore deposit convertibility, our indicator of the end of a panic. 
Evidence below is consistent with the claim that depositor beliefs changed when the liquidity of the New York Clearing House banks was apparently restored and that such information was made widely available to the public. The change in beliefs among depositors must have taken place prior to the removal of payments restrictions because net deposit inflows from the interior to New York Clearing House banks had to become positive prior to the lifting of payment restrictions.

In 1893 and 1907, gold imports from abroad after the suspension of convertibility comprised the most publicized and effective actions taken by clearing house banks during the respective panics. We highlight key observations and public announcements at specific dates to indicate a change in beliefs. We propose that actions taken by the New York Clearing House banks to increase reserve balances, the publication of those actions, and the resulting increases in reserve balances helped change depositor beliefs.

\section{New York Clearing House Aggregates}

The aggregate balance sheet of the clearing house members was published during the period of suspension, so it could be observed. In this subsection we look at data on the New York Clearing House's aggregate liquidity position during the panics. We examine data on the issues of clearing house loan certificates and the net reserve surplus (or deficit) relative to required reserves.

Using data from Andrew (1910) and from Moen and Tallman (2015), we examine how the New York Clearing House banks fared during the panics. The New York Clearing House mandated a 25 percent reserve requirement for each member bank so the periods in which the aggregate reserve balance fell below required reserves should signal distress. Figures 9, 10, and 11 show the New York Clearing House Reserve Surplus, the outstanding level of clearing house loan certificates, and the currency premium. In the figures we observe a pattern between the clearing house loan certificate volume and the reserve deficit of New York Clearing House banks. They are mirror images of each other, with a correlation of 0.68 in 1893 and -0.75 in 1907. Essentially, as currency is drained from the banks, clearing house loan certificates are issued. And, as the reserve surplus increases, the level of outstanding loan certificates falls. The figures also include the currency premium. The currency premium is also negatively correlated with the reserve surplus: -0.47 in 1893 and -0.74 in 1907.

\section{The Panic of 1893}

Wicker (2000) makes clear that the Panic of 1893 was centered in the interior of the country; it did not greatly affect New York City or the New York Clearing House in its initial stages. The reserve surplus of New York Clearing House banks diminished following the beginning of the panic in June, but the first instance of a reserve deficit in this episode was in early July, and hovered at around $\$ 5$ million. For perspective, the level of net deposits in the New York Clearing House banks ranged between $\$ 375-\$ 400$ million so the deficit was not much more than 1 percent of net deposits (or about 4 percent of reserve levels). The provision of clearing house loan certificates in late June apparently attenuated panic conditions, but did not change the direction of the reserve balance. For the Panic of 1893, the date of the suspension of payments (August 4) initiates the period of increased severity of the panic. 
In the text below, we make the case that the suspension and the subsequent gold imports are both important actions for the "change in beliefs" that was necessary for the recovery from the crisis.

Statements in the New York Tribune July 21, 1893 indicate that New York Clearing House bankers were concerned that the Chicago Clearing House had not yet agreed to issue clearing house loan certificates (in fact, they did not issue any during the Panic of 1893). Further, the newspapers described New York City banking and financial interests as expressing widespread dissatisfaction with the Sherman Silver Purchase Act of 1893 (part of this was politics, because it was far less distortionary than the Bland Allison Act which it replaced). Still, the news regarding the U.S. Treasury's gold supply expressed fears that the U.S. maintenance of the gold standard was likely under threat. And discord among the central reserve cities indicated disarray in the midst of a financial crisis. On page 2 , the article with the headline "Money Leaving the City?" emphasized the renewed drain of cash from New York City banks with shipments toward the interior. The article also mentioned that bankers had already assumed that net cash shipments out of New York City would exceed inflows. A key comment noted that bankers were considering imports of gold, but only if it could be done at a reasonable profit. In the July 22 New York Sun, an article reported that bankers bemoaned "feeble gold imports" and suggested that necessary gold imports were not feasible at existing exchange rates.

The front page article of the New York Sun on August 4, 1893 stated that a currency premium arose from the unwillingness of certain banks to respond to demands for currency, which we interpret as effectively a suspension of convertibility announcement. The article was sympathetic to New York City banks, noting that the cash drains from New York City had been protracted throughout the summer and threatened the reserve balances of the New York Clearing House banks. News of cash drains from New

York City and bank unwillingness to pay cash caused distress among the depositors of New York City banks, and added a speculative motive (get cash while you can) to withdraw cash from clearing house banks. Further, the same issue of the New York Tribune had an article with the title:

\section{ALMOST A CURRENCY FAMINE}

\section{THE SCRAMBLE FOR SMALL BILLS PUTS THEM AT A PREMIUM}

\section{HOARDING OF MONEY ONE CAUSE OF THE TROUBLE}

The suspension of convertibility was initiated August 3, 1893 and a currency premium arose by the weekend. The liquidity scramble after the suspension of convertibility was mainly observable in the New York Clearing House banking aggregates and the related currency premium. The currency premium was highest (between 4 and 5 percent) on August 8 and 9. By August 11, the reserve deficit among New York Clearing House banks was the deepest weekly reserve deficit of this panic at $\$ 16$ million.

The currency premium in New York City and elsewhere generated large-scale gold inflows from overseas because the cash premium made gold imports highly profitable during such crises. The effective gold standard in 1893 operated with the "mint parity" U.S. dollar-U.K. pound exchange rate at $\$ 4.86656$ (US dollars per British pound). In normal circumstances, the gold import (export) point was \$4.835 (\$4.899) 
approximately -0.655 percent below (above) the mint parity exchange rate. Exchange rate price differentials outside the range were sufficient to motivate shipments of gold.

An exchange rate below the normal gold import point (\$4.835) would typically motivate an inflow of gold into the US. The mechanism required the purchase (or borrowing) of British pounds at the lower exchange rate (say $\$ 4.81$ ). One would then take the pound proceeds and buy gold at the gold parity rate (\$4.86656 from official sources supporting the gold standard), and then ship the gold to the United States. The value of the gold in the United States dollars (at mint parity) is higher than the price (\$4.81) that was originally paid for pounds, so that the importer makes a profit in excess of shipping costs. In the example, $\$ 4.86656-\$ 4.81=.05656$, a $1.162 \%$ gross return (about $0.5 \%$ net of gold shipping expenses). The gain may seem small, yet it was a lucrative activity for large market participants. The activity requires two to three weeks to mature and generates an 8 to 9 percent net annual return with relatively low risk.

When the currency premium was about 4.0 percent, the value of the gold in the U.S. would be $4.86656 * 1.04$ or 5.0612 , which then made it extremely profitable to import gold to the U.S. even when the exchange rate was above the normal gold export point $(\$ 4.899) .{ }^{27}$ Hence, the suspension of convertibility, which generated the currency premium, comes prior to the observation of substantial accumulations of gold inflows. Appendix D describes the mechanism using example transactions.

We lack frequent observations of the subcomponents of aggregate liquidity measures as they were officially produced by the New York Clearing House. However, New York City daily newspapers include numerous relevant component measures of reserves. In the summary of newspaper articles below, the key quantitative contributions are the running totals of clearing house loan certificates outstanding and the accumulation of gold imports in New York City banks.

Financial market reporting turns upbeat on August 11, 1893 when the newspaper articles report that imports of gold have been negotiated. In the New York Tribune, the disturbing headline was "Banks Won't Pay Out Cash" and the text indicates that currency brokers were able to get as much as a 4 percent premium for it. However, within the same article, it was stated that the currency premium was not expected to persist for long because it had already motivated the importation of gold from overseas that was anticipated to be about $\$ 23$ million. ${ }^{28}$ On Sunday, August 13, the New York Tribune (page 4) describes how imports of gold for the week have totaled nearly $\$ 14$ million (report the following day stated $\$ 13.2$ million with $\$ 7.477$ million in US coin).

\footnotetext{
${ }^{27}$ Silber (2008, pages 28-32, and 43-47) and Officer (1986) describe the mechanisms in more detail and with further context. See also http://eh.net/encyclopedia/gold-standard/ written by Officer (2006). The shipping costs were notably higher over the period 1891-1900 than the period 1901-1910.

${ }^{28}$ This rough forecast turned out to be a relatively precise estimate of the gold inflows that accumulated through the New York City arrivals. They are generally in line with official measures available (on monthly frequency) that total approximately $\$ 40.6$ million during the month of August 1893 for the entire United States.
} 
By August 18, 1893, the New York Tribune reports that there was still a 3 percent premium on currency in spite of "heavy arrivals of gold." The article indicates the daily increase in clearing house loan certificates of $\$ 365,000$, which then increased the volume of clearing house loan certificates outstanding to $\$ 37.38$ million (as of August 17, 1893, which matches exactly the total outstanding calculated by Moen and Tallman (2015) from the individual clearing house loan certificate requests). On August 19, 1893, the New York Tribune reports that net gold imports have been approximately $\$ 17.3$ million in the prior four weeks (three of which had a currency premium), and notes the persistence of the currency premium. The article discusses that more gold shipments were on the way. By Monday, August 21, 1893 , the accumulated gold inflow is measured to be $\$ 24.46$ million, but there was no sense of cheer. Rather the newspaper article noted that the stock market was still in decline.

In the aggregate, the change in reserve balances among New York Clearing House member banks increased consistently each week after the low point in the week ending August 11 . The weekly reserve balance numbers improve following that observation largely from gold imports. The imports increase because of the profitability of gold imports arising from the large currency premium.

There was a notable change in tone in the article in the New York Tribune on Saturday, August 26, 1893. It noted that the currency premium was fast disappearing (it had fallen to about 1 percent the previous two days), that there was good indication that the Sherman Silver Purchase Act would be repealed, and that there were inflows in the form of increased deposits that were restoring the reserves of the New York Clearing House banks.

Four prominent Clearing House managers compared notes yesterday and their estimates of the gain in reserves were respectively $\$ 4$ million, $\$ 5$ million, $\$ 6$ million, and $\$ 7$ million. The net gain of the banks through the operations of the Sub-Treasury this week was over $\$ 3.7$ million and unless the shipments to the interior were heavier than is generally supposed there will be several millions of imported gold to be added, to this amount. Should another heavy reduction in the deficit in reserve be reflected to-day it is argued that the foreign gold due to-day and next week will cling largely to the hands of the commercial banks. New York Tribune, August 26, 1893, page 3.

As gold inflows helped to restore reserve levels following suspension of convertibility on August 3, reports of redeposit of funds in New York Clearing House banks (presumably by interior correspondents) all contributed to an improvement to the financial setting. The key indicators for the banking system the reserve deficit and the currency premium - become noticeably benign in newspaper articles. By August 31, the currency premium was less than one percent $(0.625 \%$ in New York Tribune page 3, column 1).

We find evidence from both the stock and bond markets that is consistent with the hypothesis. Figure 8 displays weekly stock price and bond price index measures from May 20, 1893 through November 4, 1893. These two series illustrate "return correlation" and display strong co-movement from June 4 
through July 29; each index falls notably and consistently over this period. The bond price index bottoms out August 5, 1893 just after the suspension of convertibility, and the stock price index on that date displays a slight rebound from its local trough during the previous week. For the period of suspension August 3 to September 2 - the two indexes display a modest upward trend.

\section{E. The Panic of 1907}

In terms of a sequence of events, the Panic of 1907 bears some similarity to the event sequence for the 1893 episode. There are, however, notable differences in the timing of actions by the New York Clearing House - suspension of convertibility took place at the same time that clearing house loan certificates were announced; see Table 3. The timing had no effect on the observed relationship between the currency premium and the subsequent gold inflows into New York City. However, the relationship between the gold inflows and the measures of financial distress are different. In this case, the currency premium arose at the onset of the panic and the palliative effects of gold inflows took longer to moderate the crisis conditions because depositor runs on trust companies continued even as the gold imports arrived.

During this panic, there are weekly figures for imports of gold; see Table 5 (Table 5 reproduces Table 4 in Tallman and Moen 2012, 285). The currency premium hovered around 2-3 percent for most of the first two weeks of November. The inflows of gold are associated with a decline in the premium, but it is not monotonic. The correlation between the high currency premium and the accumulated gold for the period November 2, 1907 through January 4, 1908 is minus .89. In the week of November 29, 1907, the reserve deficit shrunk slightly and the gold imports continued. By that week, the accumulated gold imports exceeded $\$ 55$ million. The currency premium remained below 2 percent in the early part of December as the reserve deficit diminished and the gold continued to accumulate. The gold imports into the U.S. continue to accumulate throughout the year and through most of January, although the import amounts dwindle after January $4 .^{29}$

The change in reserves chart displayed in Figure 9 shows how the currency premium declined as reserve inflows became consistently positive as observed in 1893 . Unlike 1893, the currency premium did not fall to zero until reserve inflows were substantially positive in January 1908.

\section{F. The Panic of 1873}

The Panic of 1873 is different from those of 1893 and 1907 for a number of reasons. First, the Panic of 1873 occurred when the U.S. was off the gold standard, having suspended that during the Civil War. Second, unlike in later panics the New York Clearing House member banks agreed to formally pool their reserves. And, finally, the New York Stock Exchange closed for ten days.

\footnotetext{
${ }^{29}$ Rodgers and Payne (2014) argue that early (and unusual) specie payment by the Banque de France to the U.S. in November 1907 was the catalyst for recovery from the Panic of 1907.
} 
Despite these differences Figure 11 displays patterns similar to those in Figures 9 and 10 for the panics of 1893 and 1907. The correlation between the outstanding clearing house loan certificates and the Reserve Surplus is minus 0.85 and the correlation between the currency premium and the Reserve Surplus is minus 0.36 . Figure 11 shows that the currency premium starts to decline prior to the Reserve Surplus becoming positive, but it does not hit zero until the Reserve Surplus starts to trend upwards. The currency premium declines as the change in reserves becomes less negative, that is, the reserves were still contracting, but at a slower rate than the sharp decline from September 19 to 26,1873 .

Because the U.S. was not on the gold standard in 1873, the mechanism discussed above whereby the currency premium created an incentive for gold to be shipped to the U.S. was not active in 1873. However, despite not being on the gold standard, gold was still necessary for payment in international trade transactions and net trade surpluses led to increased gold inflows. Sprague (1910) reports that gold did flow into the U.S.: “. . . on Friday, September 25, $\$ 2,500,000$ was taken from the Bank of England for export to the United States. This was the beginning of a considerable movement which continued until the end of October, a total of $\$ 15,000,000$ being sent to the United States from Europe" (p. 58-59). ${ }^{30}$ And, the New York Times, September 29, 1873 reported that: "The first shipments of English Gold from London to New York to arrive here next week are believed to be in good part on account of recent large loans for American Railroads and the Canadian Government" (p. 2). Still, it does not seem like this channel was as important as in the later panics.

The Clearing House actions, which were more dramatic than in the later panics, are likely to have played a large role. On September 20,1873, the day that the Clearing House stopped publishing bank-specific information, the Clearing House, the Association adopted a resolution reading in part: ". . . in order to accomplish the purposes set forth in this agreement the legal tender belonging to the associated banks shall be considered and treated as a common fund, held for mutual aid and protection, and the committee appointed shall have the power to equalize the same assessment or otherwise, at their discretion" (Commercial and Financial Chronicle, September 27, 1873, p. 411). The provision to "equalize the reserves" had also been used in 1860, at the outbreak of the Civil War. As Sprague (1910, p. 48-49) explains, since the banks were not equally strong in reserves, "the arrangement for equalizing reserves . . diminished the likelihood of the banks working at cross purposes-a danger which the use of clearinghouse certificates alone can not [sic] entirely remove." Sprague attributes the pooling of reserves and the use of loan certificates as the chief factors ameliorating the panic. Yet inflows of capital from abroad can be taken as an important signal of confidence in the solvency of the financial system in the U.S.

\footnotetext{
${ }^{30}$ Sprague (1910, p. 59-60) says that the gold movements had nothing to do with the currency premium since "exchange rates and the gold premium moved up and down with changes in the currency premium, since they were both expressed in terms of depreciated certified checks" $(p, 60)$. Inflows of gold did not affect the currency premium because of the non-monetary role of gold in a fiat money standard. We cannot rule out that the currency premium (and related gold premium on certified checks) affected the inflow of gold. It is still important as measured capital inflow.
} 
On Sept. 20, 1873, the Clearing House voted to form a committee to oversee the issuance of clearing house loan certificates, by a unanimous vote. It was determined to issue up to $\$ 10,000,000$ of certificates (NYT, Sept 21, 1873, p. 1). And, the New York Times, September 25, 1873, p. 2 summarized the actions of the Clearing House:

The action of the Associated Banks of New York in the Clearing-house this morning settled the following important points as to their course through the recent panic:

First-That having already provided $\$ 10,000,000$ Clearing Certificates of their own, which were all issued up to last night, the further sum of $\$ 10,000,000$ was authorized today, and when these are exhausted, another $\$ 10,0000,000$ will be issued. . . .

Second-The Banks resolve to stand by each other, for common defense against a common panic or emergency. They agree to certify checks payable only through the Clearing-house, which means that the debtor Bank, next morning, can settle its balances either in Certificates of the Association or in Greenbacks . . . These Greenbacks and all other Greenbacks and Treasury Certificates calling for Greenback Notes held in the Banks, are pooled or stocked for equal division, according to the capital of all the Associates.

Thirdly-The Banks resolve that any Bank in the Association "declining to participate fully in the arrangement" above noticed, for the purpose of attempting to make a factitious reputation or credit by departure from the letter or spirit of these measures of relief and mutual defense, shall, on report to the Manager of the Clearing-house, be expelled from the Association ... [italics in original] (p. 2).

These actions had a calming effect; New York Times, Sept. 23, 1873:

When the Associated Banks convened in the Clearing-house, and the real condition of the Banks said to be involved in trouble were made known, the turn in confidence was immediate, the Clearing-house Association forthwith proceeded to the issue of any part of $\$ 10,000,000$ Clearing Certificates. . . To add the better turn of affairs, it was found that the clearances of Saturday's business was [sic] decidedly easier than was apprehended. Only two banks were in arrears, and these availed at once of the Clearing Certificates agreed to be issued on Saturday.

When it was generally known on the Street that the Associated Banks were all right, and amply prepared to make common cause in the course of business, without the drawback of a single failure of their number, there was a sense of relief ... (p. 2).

New York Times, September 29, 1873, p. 2:

There is further very decided relief in Money affairs to-day, the result mainly of the sweeping action of the Associated Banks to issue their Clearing Certificates, bearing 7 
per cent. interest on the pledge of the public funds at par and of general securities at 75 per cent. of their lowest market value, including, of course, Bills Receivable or Notes Discounted, to any amount required, to relieve the difficulties growing out of their general suspension early in the week. ... The effect of this action was to satisfy the public mind that all possible mercantile embarrassment is to be averted. . . [italics in original]

The New York Stock Exchange closed on September 20 and reopened ten days later. The problem with the stock exchange was that stocks were cleared by brokers using certified checks. These involved large overdrafts from banks (see New York Tribune, September 24, 1873, p. 6, for details). The Stock Exchange Committee sent a letter to the Clearing House Committee, explaining that: "The great obstacle we have to deal with in resuming the operations of the Stock Exchange is . . the mode of settling our transactions. As long as the banks on whom checks are drawn are distrustful of each other, so long will a condition of unreasoning panic continue ... To reopen the Stock Exchange under this condition of affairs would simply . . . be the inauguration of a run upon the banks . . " (New York Tribune September 25, 1873, p. 5).

The closing of the stock exchange allowed potential buyers of distressed stocks to organize resources to buy at the low prices, which were apparently viewed as profit opportunities. New York Times, September 30, 1873, p. 1:

A still better feeling prevailed in Wall street [sic] yesterday at the close of business on Saturday. . . . Hundreds of thousands of dollars have been brought to New York by outof-town parties, who are anxious to buy good securities at low figures ... The opening of the Stock Exchange will probably tend to set this money in motion and again restore it to the banks . . as the opening of the Exchange will tend to restore confidence and render securities marketable, the banks cannot fail to again come into general use, and as a natural consequence swell their volume of deposits.

The Stock Exchange reopened on September 30, 1873. The New York Tribune of October 1, 1873 reported that: "The Stock Exchange was reopened yesterday without any renewal of the panic; before the session closed the official announcement was made that no one had failed, and that there was not a single delinquent member on earlier transactions. This virtually marks the close of the panic; public confidence has been restored in great measure, and trade and commerce are flowing back in their natural channels" (p. 1). Indeed, October 1, 1873 is the date of highest currency premium, which generally declines after that date; see Figure 7A for 1873, Figure 7B for 1893 and Figure 7C for 1907.

The reopening of the Stock Exchange aided the banks in being able to sell collateral they had seized when borrowers using the call loan market had defaulted. New York Times, October 6, 1873:

The reduction in the Clearing Certificates is no doubt due to the recovery in Stock values after the reopening of the Exchange. This enabled some of the Wall Street Banks that held demand loans on Stocks, which they could not collect while the Exchange remained 
closed, and had to be repledged in the extremity of the panic to the Clearing-house at 75 per cent. of their lowest market value, to retire their Certificates. . . . The relief of the Clearing-house by the liquidation of loans to Brokers, some of which were forced loans . .. will enable the Clearing-house committee to carry through certain large Banks whose failure would not only add fuel to the crisis, but greatly distress mercantile interests ... (p. 2).

During the crisis there was a great deal of discussion about what the government could and could not legally do. See Commercial and Financial Chronicle, September 27, 1873, p. 406. The U.S. Treasury was limited in the actions that it could legally undertake. The government did redeem some bonds, paying out $\$ 13,000,000$ in currency. NYT, Sept 23, 1873, p. 2: "The Treasury Office to-day was enabled to buy about $\$ 3,500,000$ United States 5-20s at the rate of 110.72 cent. . . " And, New York Times, September 29,1873, p. 2: "The Treasury in the last week has paid out, at all points, $\$ 35,000,000$ Greenback Notes. Of this sum $\$ 22,000,000$ Notes were exchanged for the $\$ 5,000$ and $\$ 10,000$ Certificates, (heretofore used for clearings in the great cities) and pay for United States 5-20s. The Treasury has also supplied since the panic set in about $\$ 3,000,000$ Circulating Notes to the new National Banks of the South and West" (p. 2). Sprague (1910, p. 42) argues that this was of little consequence in relieving the panic because almost all the bonds were purchased from savings banks and they were unwilling to deposit the money with banks.

\section{G. Summary}

We argued above that depositors' beliefs changed when the liquidity of the New York Clearing House was restored. We can summarize this with regressions that relate our proxy for beliefs, the currency premium, to the level of clearing house reserves.

We estimate a simple regression to highlight the contemporaneous relationship between the changes in the level of reserves held at the New York Clearing House member banks and the changes in the currency premium over the three National Banking Era panics in which there was a suspension of the convertibility of deposits into currency. Equation 1 provides a description of the relationship:

$$
\Delta C P_{t}=\alpha+\beta_{1} \Delta \text { Reserves }_{t}+u_{t}
$$

where: $\mathrm{CP}=$ currency premium (average for the week) and RSD = Reserves at the end of the week held by New York Clearing House member banks.

Table 6 displays the results. The estimated coefficient on the change in reserves is negative in each of the sub-sample periods (each individual panic) as well as for the pooled estimate. We note that there are only 22 observations for the pooled sample and 6, 6, and 10, respectively, for the three sub-samples. The limited number of observations is why we focus on a simple estimation strategy. Still, we estimate the standard errors using a heteroskedastic consistent estimator and find that the coefficient estimates

for change in reserves to be statistically different from zero for each of the periods 1893, 1907 and the pooled sample. The results emphasize how the currency premium spikes up as the reserves decline and 
flow out of the banking system and vice versa, the currency premium falls as reserves come back into the New York Clearing House banks signaling the change in depositor beliefs about the prospects for the financial system. ${ }^{31}$ Empirical results are similar for all regressions if we use as the explanatory variable the change in the reserve surplus or deficit (relative to required reserves).

\section{Aftermath}

How well did the Clearing House do in avoiding bank failures? If panics were essentially an information issue about which banks were insolvent, as claimed by Gorton (1988), then it should be the case that very few clearing house member banks actually failed. To address this, we ask: Did clearing house members fail during the panics or shortly after? We address this question in several ways.

First, the Annual Report of the Comptroller of the Currency (1920, p. 56-73) lists all the national bank failures and the reason for the failure up until that date. There are 33 possible causes of failure and each bank failure is assigned one cause. One reason for failure is "Closed by run." There are seven cases of banks closed for this reason. None of these cases are banks in New York City.

Secondly, Dudley $(1890$, p. 6$)$ lists the New York Clearing House members that left the clearing house for some reason, up to 1890 . He lists 24 members that left. Of these, the following occur during or just after a panic:

- National Bank of the Commonwealth, September 22, 1873, in hands of Receivers.

- Metropolitan National Bank liquidated November 18, 1884;

- Marine National Bank failed May 6, 1884.

The first day of suspension in the Panic of 1873 was September 22. And, the Panic of 1884 started in May. The Comptroller's Annual Report has the National Bank of the Commonwealth listed as failing due to "Injudicious banking and depreciation of securities," and this occurred at the start of the panic. The Metropolitan National Bank is not listed in the 1920 Comptroller's Annual Report. But, in the Comptroller's Annual Report of 1901, the Metropolitan is listed as having been voluntarily liquidated. ${ }^{32}$ The Marine National Bank is listed as closed due to "Fraudulent management, excessive loans to officers and directors, and excessive loans to others."

\footnotetext{
${ }^{31}$ The currency premium data are the averages of daily figures calculated from newspaper reports and remain preliminary as we look to fill in missing observations. Presently, missing observations are skipped rather than assumed to be zero.

${ }^{32}$ However, it is reasonable to conclude that the demise of Metropolitan National Bank in 1884, though officially categorized as "voluntarily liquidated," is essentially a bank closed by extended depositor runs. What we find notable is that the bank - having deposits contract from $\$ 7.4$ million (May 17) to $\$ 1.2$ million (June 21) in just over a month - was able to continue its operations until mid-November. The key point is that the closure did not occur in the midst of the panic. The delay of that outcome was essential to the strategy of the New York Clearing House.
} 
Finally, another way to answer this question is to check clearing house membership before the panic and compare it with the membership list eight months later, to see if banks failed (or merged) in the aftermath. That is, a bank may have been propped up by the clearing house during the period of suspension, but then allowed to fail afterwards.

\section{Panic of 1873}

The NY Clearing House issued loan certificates on September 20, 1873. Just before the panic, on September 13, 1873, The Commercial and Financial Chronicle listed sixty clearing house member banks. Convertibility was resumed on November 1, 1873. On June 6, 1874, Commercial and Financial Chronicle listed the same sixty clearing house member banks. No clearing house members disappeared.

\section{Panic of 1884}

The NY Clearing House issued loan certificates on May 15, 1884. Before the panic, on February 23, 1884, the Commercial and Financial Chronicle listed sixty three clearing house member banks. By September 1,1884 , the only clearing house loan certificates outstanding were issued to Metropolitan National Bank; clearing house loan certificates are entirely cancelled on September 23, 1886. On October 11, 1884, the Commercial and Financial Chronicle listed sixty one clearing house member banks. The two banks missing are the Wall Street Bank and Marine National Bank of New York. Otherwise the two lists are the same.

The Annual Report of the Comptroller of the Currency (December 1, 1884) states (p. XXXIII) that the Marine National Bank failed on May 6, 1884, and lists the bank as in voluntary liquidation (p. CLXXVIII). Wall Street Bank was charted by New York State. In the Annual Report of the Superintendent of the Bank Department of the State of New York, 1885, the Wall Street Bank is listed as failed, as of April 11, 1884 (p. viii). The narrative suggests that Metropolitan National Bank was aided so it would not fail during the crisis period in May. In its situation (losing so large a volume of deposits), failure or liquidation seemed inevitable. It voluntarily liquidated November 18, 1884, months after the panic subsided. Metropolitan National Bank still had over $\$ 5$ million in clearing house loan certificates when it voluntarily liquidated in November 1884; their clearing house loan certificates were the last cancelled as described above. ${ }^{33}$

Although Dudley (1890) and the Comptroller's Annual Report do not mention the Wall Street Bank, Clews (1888, p. 521) lists it has having failed in August 1884. According to Bayles (1917), there was a posted notice saying that the bank had failed "owing to irregularities on the part of the cashier" (p. 273). Bayles says that the "Wall Street National Bank . . .changed on the $19^{\text {th }}$ day of October, 1883 [sic?], to a State bank ... It failed in less than a year from that time" (p. 274).

\section{Panic of 1890}

33 Metropolitan National Bank requested a reduction in the interest rate on their outstanding clearing house loan certificates in early 1885, a request that was granted by the New York Clearing House. 
Clearing house loan certificates were issued November 12, 1890, and finally canceled on February 7 , 1891. Comparing the list of New York clearing house members on November 1, 1890 to May 16, 1891 shows that of the sixty four members prior to the crisis, there was only one failure, North River Bank. North River was a state bank; it was liquidated in 1891.

\section{Panic of 1893}

Clearing house loan certificates were issued June 21, 1893, and finally canceled on November 1, 1893. Comparing the list of New York clearing house members on May 27, 1893 to December 23, 1893 shows that of the sixty four members prior to the crisis, none failed. This finding is consistent with Wicker (2000) who argues that the Panic of 1893 was not focused in New York City, but rather among interior locations.

\section{Panic of 1907}

Clearing house loan certificates were issued on October 26, 1907, and finally canceled on March 28, 1908. Comparing the list of New York clearing house members on October 19, 1907 to August 1, 1907 shows that of the fifty three banks in the New York clearing house prior to the crisis, four failed during the crisis. The banks not listed on the March 28, 1908 list were the Mechanics and Traders Bank, the Oriental Bank, the First National Bank of Brooklyn, and the National Bank of North America. However, the Annual Report of the Attorney General of the State of New York, for the year ending December 31, 1908 , says that the Mechanics and Traders Bank did reopen as the Union Bank of Brooklyn. The Attorney General of New York says that only one bank did not resume (Report, p. 31), so it seems that only the Oriental Bank, of the state banks, failed. The same report shows states that the Oriental Bank's assets were turned over to the Metropolitan Trust Company. Neither of these banks is listed as closed/liquidated by the Superintendent of Banks of New York (Annual Report of 1908). The Annual Report of the U.S. Comptroller of the Currency, 1907, lists the First National Bank of Brooklyn as insolvent and closed on October 25, 1907, the day before loan certificates were issued.

The National Bank of North America was liquidated during the crisis, but without losses to creditors. "That the National Bank of North America was not insolvent when it was closed was fully demonstrated by the rapid liquidation of its affairs under the receivership. Its creditors were paid in full with interest from the date of closing ... The receivership was finally closed October 31, 1908." (See Kane (1922), p. 272).

The Wall Street Journal, October 16, 1908, p. 8, notes that "there were fifteen institutions in New York and Brooklyn altogether which closed their doors, either at the height of the panic in October or subsequently as a result of the bank. Of these fifteen three were national banks, eight were state banks and four were trust companies." "But far more interesting . . . is the fact that the depositors of these suspended institutions have not or will not, lose a dollar of their money."

Excluding the one case of voluntary liquidation and the case where there was liquidation but no apparent depositor losses, the final tally of failures of New York Clearing House members appears to be: 
two banks in 1884 the Wall Street Bank and the Marine National Bank of New York), one in 1890 (the North River Bank), and two in 1907 (the Mechanic's' and Traders Bank and the Oriental Bank). There were no bank failures during the Panics of 1873 and 1893 in New York City. And there are a few ambiguous cases as well. But, overall there were few failures.

Gilpin and Wallace (1904): "Since 1860, a total of $\$ 168,774,000$ in loan certificates have been issued at various periods, and all were duly redeemed without the loss of a dollar" (p. 18).

\section{Conclusion}

Bagehot's rule-that the central bank should lend against good collateral at a high rate-is the prescription for central banks to fight crises. See Bagehot (1873). The New York Clearing House lent in the form of loan certificates against good collateral at a high rate. This was the policy followed not only by the New York Clearing House during panics but also by the major central banks during the financial crisis of 2007-2008. ${ }^{34}$ But, for both the Clearing House and the modern central banks, there was more than that. And what Bagehot left out is very important: secrecy of lending programs, specifically the anonymity of borrower identity to the general public. In the most severe National Banking Era crises as in the crisis of 2007-2008, there were lending programs that were announced to the public, but the lending to banks was secret -- to keep the identities of weak banks from being revealed. This forced short-term debt holders to focus on the banking system. To keep weak banks from being identified, the clearing house prohibited the publication of bank-specific information and kept their lending program, loan certificates, secret. In the most severe crises, aaving the financial system meant not letting weaker banks get picked off one by one.

In the case of the Clearing House, there was, first, the suspension of the publication of individual bank information and then restrictions on deposit convertibility (into cash), which kept the financial system from being liquidated in runs. ${ }^{35}$ Issuing loan certificates legally bound the clearing house member banks together. Jointly, these actions forced depositors to focus on the solvency of the clearing house rather than individual banks. The opening of the market for certified checks allowed the currency premium to reflect depositor beliefs about the clearing house solvency.

In the crisis of 2007-2008 the government was able to use "overwhelming force," as explained by then Treasury Secretary Tim Geithner (2014) and by former Federal Reserve Board Chairman Ben Bernanke (2015: 234). The restoration of confidence involved demonstrating that the government has committed enough resources to support the banking system. This was the Troubled Asset Relief program (TARP). See Gorton (2014). This was also the case in 1914 when Treasury Secretary William McAdoo used a "sledgehammer" to deal with the panic (see Silber 2007: 6). But, prior to the Federal Reserve and a

\footnotetext{
${ }^{34}$ In the recent financial crisis, Ben Bernanke, Mervyn King and Mario Draghi, the respective heads of the Federal Reserve System, the Bank of England, and the European Central Bank, reported that they followed this advice; see Bernanke (2014a and 2014b), King (2010) and Draghi (2013).

${ }^{35}$ Though suspension was not announced by the clearing house, there was tacit approval and the recognition that when loan certificates were issued in the most severe crises, all banks would have to suspend.
} 
powerful Treasury, these tools were not available. The New York Clearing House simply did not have these powers.

So, how could the New York Clearing House convince depositors of its solvency? During the suspension periods of the National Banking Era, the New York Clearing House sometimes conducted special bank examinations. But, the NYCH had to take additional action to make a compelling signal to depositors that the banking system was solvent and liquid. In the panics of 1893 and 1907, the key public signal was the large-scale infusion of gold (net inflows) into the banking system from abroad. Newspaper accounts of the imports highlight the increase in available liquidity in the New York financial market along with reliable accounts of contracts for gold imports that would arrive in the weeks to follow. A more subtle signal arises from the fact that foreign holders/investors (sources of gold) were willing to send gold to the US, and foreign lenders were willing to lend to the US banks to facilitate the gold shipments. The shipments and the credit extensions were signals of confidence in the solvency and liquidity of the US financial market.

Restoring confidence in the Panics of 1893 and 1907 panics was aided by the proper functioning of a gold standard in the presence of a currency premium. This was not the case in the Panic of 1873 . Some gold was imported and the U.S. Treasury did repurchase some U.S. government bonds. And, once the stock market reopened, banks could sell the stock they had seized as collateral for defaulted call loans. So, there was no single mechanism the built up bank reserves.

It is important to note that the New York Clearing House behaved differently in the less severe financial instances of 1884 and 1890 . In these crises, there was no suspension of convertibility so there was no currency premium. In the absence of a currency premium, there were no unusual gold inflows arising from a currency premium. In these "incipient" panics, the decision not to impose suspension likely

arose because there was not a serious shortage of cash reserves among the New York Clearing House banks in the aggregate. As a result, the New York City financial market in general was not at risk. Without notable aggregate risk, the clearing house actions could deviate from standard routine; for example, there was the publication of the identity of clearing house loan certificate borrowers in 1890, and the balance sheet information for individual clearing house member banks was only suppressed for two weeks in 1884. This is important because the New York Clearing House was not preventing bank failures, but rather alleviating risks to the financial system in general. When the system was not at risk, the clearing house actions could be different.

\section{Appendix A: Details of Table 3}

\section{Introductory Comments}

The dating for the dates of the panic start (column 1), the date of suspension of convertibility (column 4 ), and the date of resumption of convertibility (column 7) are not as clear as indicated in the tables. There are no clear-cut dates for these events. The literature usually defines the panic start date as the date of the first failure of a large bank that led to other related suspensions. Independent suspensions before this date were not considered part of the crises. With regard to the suspension and resumption 
dates, it is important to differentiate between the different forms of suspension of cash payment i.e. convertibility that took place in different crises. Wicker (2000) and Sprague (1910) highlight the difference between restricting payments in New York City and shipments to the interior. Restriction within NYC was always partial and took the form of "checks had to be certified through the $\mathrm{CH}^{\text {" and/or }}$ advance notice of withdrawal for savings banks. The Times and the Chronicle often do not mention the exact form and extent of suspension. The resumption dates are also somewhat vague. In general, initial events are somewhat chaotic at the start of the panic. And resumption seems to happen quietly. There are no clearinghouse announcements of suspension or resumption of convertibility. Each date is discussed further below.

\section{Details of Table 3}

Please refer to Table A1 which identifies each cell in Table 3. Each cell is then discussed below.

\section{Panic of 1873}

A1: Although other companies failed before this date, subsequent runs began on other banks and brokerage houses in NYC and the interior only after Jay and Cooke and Co.'s failure. Wicker (2000) agrees, saying that " . . but the shock that gained national attention was the failure of Jay Cooke and Co. on September $18^{\text {th }} \ldots$ ". (Wicker (2000, p. 20)).

"The suspension [of stock brokers Kenyon, Cox and Co] was of far less general influence than that of Messrs. Jay Cooke and Co., which occurred on Thursday [September 18], which was followed by the failures of a number of smaller stock brokerage firms..." (Commercial and Financial Chronicle, September 20, p. 382).

A2: The last individual and aggregate bank data were published for September 20. They were not published after this date (New York Times Financial Affairs, September 21, 1873; Commercial and Financial Chronicle, September 27; October 4, 1873).

A3: The official announcement issued by the Clearing House on September 20 was printed in the New York Times and the Chronicle (Commercial and Financial Chronicle, September 27; New York Times September 21, 1873). The U.S. Comptroller of the Currency, Annual Report, 1907, p. 66, gives the date as September 22, 1873.

A4: $\quad$ The Clearing House decided on September 22 that all checks from Clearing House member banks must be certified through the Clearing House. The Clearing House announced on September 24 that all checks when certified by any bank should also be first stamped or written "Payable through the Clearing House" (New York Times, September 25, 1873; New York Times, Financial Affairs September 23, 1873).

The adoption of this resolution involved the partial suspension of cash payments by the banks. It did not signify that no money would be paid out to the depositors, but it placed the dwindling supply of currency more within the control of the Clearing House Committee. In fact, suspension 
was also only limited to NYC, currency was paid to the interior as freely as before (see Wicker (2000, page s21, 32); Also see Sprague (1910), page 54).

The equalization and pooling of reserves policy was also announced on September 20, 1873.

A5: $\quad$ New York Times and Tribune.

A6: $\quad$ New York Times and Tribune.

A7: On Oct 24, the Clearing House announced the end of the reserve pooling arrangement from November 1 onwards. Certificates continued to be in use until natural retirement. It is not clear if complete payment of cash was also implemented on that day (Commercial and Financial Chronicle, November 1, page 589; New York Times, October 24).

Wicker also says that the resumption of cash payment was on November 1 , but there was no mention of resumption of cash payment or certification of checks in the Chronicle and the New York Times.

A8: U.S. Comptroller of the Currency, Annual Report, 1907, p. 66.

A9: Only the total bank statement for November 15 and November 22 was published in the November 29 issue (Commercial and Financial Chronicle, November 29, page 715).

Individual Bank statements for the week of December 6 were issued again for the first time in the December 13 issue (Commercial and Financial Chronicle, December 13, page 799).

A10: U.S. Comptroller of the Currency, Annual Report, 1907, p. 66.

\section{Panic of 1884}

B1: The Marine National Bank (a Clearing House member) and the Wall Street brokerage firm of Grant \& Ward failed on Tuesday, March 6 (Commercial \& Financial Chronicle, 10 May 1884, page 563; New York Times, "Wall Street Startled", 7 May 1884, page 1).

The $\$ 3$ million fraud committed by the president of the Second National Bank (a Clearing House member) was made public on Wednesday, March 14, before the stock market opened \{Commercial \& Financial Chronicle, 17 May 1884, page 589; New York Times, "Two Millions Absorbed", 14 May 1884, page 1).

The closing of the Metropolitan Bank (a Clearing House member) on Wednesday, March 14, was the "final shock" and the "immediate event which started the panic" (Commercial \& Financial Chronicle, May 17, 1884, page 582, 589; New York Times, "On the Verge of a Panic", May 14, 1884, page 1). 
B2: The detailed weekly bank statement for May 17 was published. While the Metropolitan and Second national banks were listed, the Marine bank was not shown (Commercial \& Financial Chronicle, 24 May 1884, page 617).

The detailed weekly bank statement for May 24 was not published. Instead, the May 17 statement was re-published (Commercial \& Financial Chronicle, 31 May 1884, page 644).

B3: Authorized May 14 (Sprague (1910, page 113, quoting the Annual Report of the Comptroller of the Currency, 1884, page 33; Commercial \& Financial Chronicle, May 17, 1884, page 589; New York Times, "On the Verge of a Panic", May 14, 1884, page 1). The U.S. Comptroller of the Currency, Annual Report, 1907, p. 66, gives the date as May 15.

B4: $\quad$ "There was no suspension of gold and currency payments at any point" (Sprague (1910, page 114, quoting the Annual Report of the Comptroller of the Currency, 1884, page 33).

B5: $\quad$ New York Times, Tribune, and Wall Street Journal.

B6: Not applicable.

B7: Not applicable. See B2 above.

B8: $\quad$ U.S. Comptroller of the Currency, Annual Report, 1907, p. 66.

B9: The detailed weekly bank statement for May 31 was published. While the Metropolitan and Second national banks were listed, the Marine bank was not shown (Commercial \& Financial Chronicle, June 7, 1884, page 670).

The Chronicle commented that resumption of the detailed weekly bank statement was "one fact which contributed to the restoration of confidence"(Commercial \& Financial Chronicle, June 7, 1884, page 668).

B10: $\quad$ U.S. Comptroller of the Currency, Annual Report, 1907, p. 66.

\section{Panic of 1890}

C1: After leaving the discount rate unchanged at its regular weekly meeting Thursday, November 6, the Bank of England unexpectedly raised the discount rate from $5 \%$ to $6 \%$ Friday, November 7. This action was "unusual" and created a feeling of "uneasiness" (Commercial \& Financial Chronicle, November 8, 1890, page 624; New York Times, "Financial Affairs", November 8, 1890, page 6).

On Monday, November 10, a false report circulated at the NYSE that the Bank of England raised the discount rate to 7\% (Commercial \& Financial Chronicle, 15 November 1890, page 667). 
C2: The detailed weekly bank statement for November 15 was published (Commercial \& Financial Chronicle, November 22, 1890, page 705). But, the detailed weekly bank statement for November 22 was NOT published. Instead, the November 15 statement was re-published (Commercial \& Financial Chronicle, November 29, 1890, page 741).

C3: Clearing House loan certificates were authorized on Tuesday, November 11 (Sprague (1910, page 141-142; Commercial \& Financial Chronicle, November 15, 1890, page 667; New York Times, "Firms Fail, Banks Shaken", 12 November 1890, page 1). The U.S. Comptroller of the Currency, Annual Report, 1907, p. 66, gives November 12 as the first date of issuance.

C4: "The issue of loan certificates was not followed by the suspension of payments by the banks" (Sprague (1910, page 145).

C5: Not applicable.

C6: Not applicable.

C7: Not applicable. See C2 above.

C8: $\quad$ U.S. Comptroller of the Currency, Annual Report, 1907, p. 66.

C9: The Chronicle noted that on March 7, the clearing house banks "resumed the publication of their detailed statement, which publication has been suspended since November 15" (Commercial \& Financial Chronicle, 14 March 1891, page 406).

C10: U.S. Comptroller of the Currency, Annual Report, 1907, p. 66.

\section{Panic of 1893}

D1: Sprague (1910) refers to Sunday, June 4, as the "week when panic may be said fairly to have begun" (Sprague (1910, page 418)).

D2: The detailed weekly individual bank statements for June 10 were published (Commercial \& Financial Chronicle, June 17, 1893, page 999). But, the detailed weekly individual bank statements for June 17 were NOT published. Instead, the June 10 statement was re-published. The aggregate bank statement continued to be published (Commercial \& Financial Chronicle, June 24, 1893, page 1046, 1048; New York Times, "Financial and Commercial", June 18, 1893, page 14).

D3: Loan certificates were authorized on Thursday, June 15 (Sprague (1910, page 170, 409-410; Commercial \& Financial Chronicle, June 17, 1893, page 997; New York Times, "Certificates to Be Issued", June 16, 1893, page 8). The U.S. Comptroller of the Currency, Annual Report, 1907, p. 66 , gives the date of first issuance as June 21. 
"The NYCH on June 15 took the unusual step of authorizing $\mathrm{CH}$ certificates even though there was no banking disturbances in NYC" (Wicker (2000, page 64)).

D4: "On August 3, the New York banks severely restricted, though they did not completely halt, the shipment of currency ..." (Wicker (2000, page 77)).

The presidents of almost all of the New York savings banks met on July 28* and recommended that the bank trustees begin to enforce legal notice of withdrawals "when need of such action arises." This action was "unexpected and caused some uneasiness." While each bank would establish its own policy, a common rule was that withdrawals over $\$ 100$ required 30 days' notice, while withdrawals over $\$ 300$ required 60 days' notice (New York Times, "Banks May Hold Deposits", July 29, 1893, page 1, and New York Times, "Financial and Commercial", July 30, 1893, page 14).

Sprague (1910) indicates that a partial suspension of cash payments began with the New York banks on August 1 or 2, but that suspension was "at no time complete" (Sprague (1910, pages 177-178, 181-182).

The Chronicle indicates that the New York savings banks began to enforce "legal notice for the withdrawal of deposits" during the week ended August 5 (Commercial \& Financial Chronicle, August 5, 1893, page 196).

* The date of decision was Friday, July 28th. The date of enforcement ranges from Aug 1 to Aug 3.

D5: $\quad$ Tribune and Wall Street Journal.

D6: $\quad$ Tribune and Wall Street Journal.

D7: Sprague (1910, p. 189-190) indicated his certainty that the banks that regained the $25 \%$ reserve ratio by September 2 "then removed all restrictions upon payments."

The Chronicle states that the "30-day notices required by the savings banks of [New York] for the withdrawal of deposits expired in many cases on Thursday [August 31], and payment was made either with gold or checks payable through the Clearing House, as depositors chose" (Commercial \& Financial Chronicle, September 2, 1893, page 356).

The Times noted the August 31 expiration date and indicated that there was "no longer difficulty" in cashing checks under $\$ 5,000$ (see New York Times, "Financial and Commercial", 1 September 1893, page 6).

D8: $\quad$ U.S. Comptroller of the Currency, Annual Report, 1907, p. 66.

D9: The Chronicle noted in each issue that the detailed weekly bank statement would not be issued as long as any clearing house loan certificates remained outstanding. 
The last certificate was canceled November 1 , and the detailed statement was again published for the following Saturday, November 4, in the November 11 issue. In the November 4 issue, the June 10 statement was published again (Commercial \& Financial Chronicle, November 4 and November 11, 1893, pages 754 and 800; New York Times, "Financial and Commercial", November 5, 1893, page 14).

Several earlier reports in the Chronicle also point to this date:

“... Boston...last certificates cancelled today; while in NYC the amount is down to 2,785,000, and this will be extinguished in a few days...." (Commercial \& Financial Chronicle, October 21, page 668).

“. . . cancellation of $\mathrm{CH}$ certificates this week have been $1,255,000$, reducing the amount outstanding to $1,525,000$. The expectation now is that all the certificates will be retired October 31..." (Commercial \& Financial Chronicle, October 28, Page 701).

D10: U.S. Comptroller of the Currency, Annual Report, 1907, p. 66.

\section{Panic of 1907}

E1: This date is debatable. On October 16, 1907 rumors about treachery among United Copper Board of Directors became known, setting off speculations that these directors may be involved in bad business elsewhere., leading to a series of other temporary runs/failures e.g. Mercantile National Bank. However, United Copper itself was not a firm of prime importance and it could be argued that the crises actually began on October 22, when the prime trust company Knickerbockers suspended, leading to a series of trust company suspension. (See New York Times October 17, 23 1907.) Wicker marks the start of the crisis with the failure of the Knickerbocker Trust on October 22. Earlier events were marked as 'pre-panic' since it only concerned the copper market related banks without general loss of confidence." (Wicker (2000), pages 9 , 83.)

E2: The last individual bank statements (for both member and non-member banks) were published for October 26 in the Chronicle. On November 1, they were announced not to be published again for the following week i.e. November 2 in the Times. The aggregate statements continued to be published. (Commercial and Financial Chronicle November 2, page 1124; New York Times November 1).

E3: Clearing house certificates were authorized on October 26 (Sprague, page 271; New York Times October 27, 1907).

E4: According to Sprague, cash payments were suspended together with the authorization of clearing house certificates, which is October 26 (Sprague, page 260). Saving banks began to enforce legal notice of withdrawals for 60 or 90 days (New York Times, October 26, 1907). 
The form of suspension refuse to meet currency demands from the interior and locally....proof?!

E5: $\quad$ Tribune and Wall Street Journal.

E6: $\quad$ Tribune and Wall Street Journal.

E7: "Cash payments were not completely resumed until the beginning of January. For exactly two months, money was regularly bought and sold at a premium in NYC" (Sprague, page 278). Wicker cites the date of resumption as January 1 (Wicker, page 9).

E8: $\quad$ U.S. Comptroller of the Currency, Annual Report, 1908, p. 65.

E9: Individual bank statements (for both member and non-member banks) were published for February 8 onwards in the February 15 Chronicle issue. As a new measure, non-member state and national banks' aggregate statement was also published in addition to the aggregates of member banks (Commercial and Financial Chronicle, February 15, page 403; New York Times, February 9).

E10: U.S. Comptroller of the Currency, Annual Report, 1908, p. 65. 


\section{Details of Table 4}

Please refer to Table A1 which identifies each cell in Table 4. Each cell is then discussed below.

\section{Panic of 1873}

A1. The failure of Jay Cooke \& Co. Philadelphia Bulletin, 9/18/1873; Philadelphia Inquirer, 9/19/1873, p.1; and Philadelphia Record, 9/19/1873.

A2. Philadelphia Record, 9/30/1873; Philadelphia Bulletin, 9/29/1873. However, the Philadelphia Inquirer published bank-specific information on page 6 of its $9 / 30 / 1873$ issue and started withholding such information the following issue on 10/7/1873. In the 9/30/1873 issue, the Philadelphia Record reported that "The clearing house made no statement of the condition of the banks yesterday. We think this policy is a mistake."

A3. Philadelphia Inquirer, 9/24/1873, p. 1: "The clearances of the Gold Exchange Bank are completed, and balances will be paid as usual. $\$ 1,500,000$ of loan certificates have been issued by the clearing house today. It is probable that the whole ten millions of loan certificates will be taken up, and the clearing house association will increase the amount." Philadelphia Record, 9/26/1873: "The Loan Committee of the Clearing House Association decided to issue an additional $\$ 10,000,000$ of loan certificates. These are available for the immediate use of the banks connected with the association. The clearing house committee issue $\$ 2,500,000$ in loan certificates yesterday, making a total thus far of $\$ 12,500,000$. The banks have also agreed to buy up $\$ 10,000,000$ of government bonds of individual holders, at the value say of 3 or 1 per cent above the government price, and, turning them into the treasury at their own cost, to draw out the green backs for the public uses." Philadelphia Record, 9/27/1873: "The clearing house commenced the issue of loan certificates yesterday, the amounts of which were in sums of 5 thousand and 20 thousand and are to be used only in the settlements between the banks."

Cannon (1910, p. 86-87):

In like manner the Philadelphia association now, for the first time, entered upon the plan so successfully followed in New York since 1860, by appointing a loan committee, with authority to issue clearing-house loan certificates. Such certificates were authorized by resolution adopted September 24, 1873, and amended October 18, 1873, to read as follows:

For the purpose of enabling the banks, members of the Philadelphia Clearing House Association, to afford proper assistance to the mercantile and manufacturing community, and also to facilitate the inter-bank settlements resulting from their daily exchanges, we, the undersigned, do bind ourselves by the following agreement on the part of our respective banks, namely: 
First. That the clearing-house committee be, and that they are hereby, authorized to issue to any bank, member of the association, loan certificates bearing 6 per cent interest on the deposits of bills receivable and other securities to such an amount and to such percentage thereof as may in their judgment be advisable. These certificates may be used in settlement of balances at the clearing house, and they shall be received by creditor banks in the same proportion as they bear to the aggregate amount of the debtor balances paid at the clearing house. The interest may accrue upon these certificates shall be apportioned monthly among the banks which shall have held them during that time.

Second. The securities deposited with the said committee shall I held by them in trust as a special deposit, pledged for the redemption of the certificates issued thereupon, the same being accepted by the committee as collateral security, with the express condition that neither the clearing-house association, the clearing-house committee, nor an member thereof shall be responsible for any loss on said collaterals from failure to make demand and protest, or from any other neglect ( omission other than the refusal to take some reasonable step which it said depositing bank may have previously required in writing.

Third. On the surrender of such certificates, or any of them, by the depositing bank, the committee will indorse the amount as a payment on the obligation of said bank held by them, and will surrender appropriate amount of securities, except in cases of default of the bar in any of its transactions through the clearing house, in which case the securities will be applied by the committee, first to the payment of outstanding certificates with interest; next to the liquidation of any indebtedness of such bank to the other banks, members of the clearing house association.

Fourth. The committee shall be authorized to exchange any portion of said securities for others, to be approved by them, and shall have power to demand additional securities at their own discretion.

Fifth. That the clearing-house committee be authorized to carry in full effect this agreement, with power to establish such rules and regulations for the practical working thereof as they may deem necessary and any loss caused by the nonpayment of loan certificates shall be assessed by the committee upon all the banks in the ratio of capital.

Sixth. The expenses incurred in carrying out this agreement shall t assessed upon the banks in equal proportion to their respective capitals.

Seventh. That the clearing-house committee be and they are hereby authorized to terminate this agreement upon giving thirty days' note thereof at any stated meeting of the clearing-house association. 
The issue of certificates made in conformity with the foregoing resolution reached the maximum amount outstanding at one time, namely, $\$ 6,285,000$, on December 1, 1873.

A4. Philadelphia Record, 9/22/1873; the Union Banking Company and E W Clark \& Co. closed doors.

A5. Philadelphia Inquirer, 9/26, 1873, p.1; Philadelphia Record, 9/26/1873, p.4. According to Inquirer: "The banks in the Clearing House Association are pooling their greenbacks, as agreed yesterday. One or two, which stood exceptionally strong, refused at first to put their legal tenders in, but finally concluded to do so rather than be expelled from the association. Money is still unquotable; greenbacks have been exchanged today for certified checks all the way from 1 to $3.5 \%$ premium. The loan committee of the clearing house issued up to this evening $\$ 17,000,000$ of certificates."

A6. The Philadelphia Record 10/25/1873 indicated that currency was on par with certified checks first on $10 / 24 / 1873$. However, according to the Philadelphia Inquirer, there was likely a positive currency premium by at least as late as 10/27/1873, p.6: "How the payment of currency in Philadelphia, when it is at a premium in NY, would cause money to flow from us until our banks were drained of their cash resources, and the disastrous results of such a policy, may be readily imagined by a tyro in financial matters."

A7. Philadelphia Inquirer, 11/18/1873, p.6: "Money was quite as abundant and easy at the resumption of business yesterday as at the close of last week."

A9. Philadelphia Inquirer, 12/2/1873, p.6.; Philadelphia Record, 12/2/1873; Philadelphia Bulletin, 12/1.

\section{Panic of 1890}

B1. Cannon (1910), p. 91; Philadelphia Inquirer, 11/12/1890, p.1-2; Philadelphia Record, 11/12/1890, p.1 and p.8; Press, 11/12/1890, p. 1.

B2. Philadelphia Inquirer, 11/18, p.7; Philadelphia Record, 11/18/1890.

B3. Cannon (19190), p. 94. Philadelphia Inquirer, 11/19, p.7: "The Philadelphia Clearing House Association yesterday took such action in regard to the money market as the condition of the case seemed to warrant. It was decided to issue to the banks making appellation therefor certificates to be used in settling balances between themselves. This is precisely the action that has been taken by the Clearing House Association of NY and Boston and binds the Clearing House banks closely together. The credit of one is now the credit of all. Any bank having in its vaults good collateral or acceptable mercantile paper can obtain credit with all the other banks. There is a bank upon which a check is drawn need not pay the collecting bank in cash, but may pay in a due bill secured by ample credit In this way the resources of all the banks in the Clearing House Association are practically at the command of each bank" 
B4. Barker Bros. \& Co. suspended on $11 / 20$, but no widespread suspension ensued in the city. See Philadelphia Inquirer, 11/21, p.7.

B5. Does not apply.

B6. Does not apply.

B7. Does not apply.

B8. Does not apply.

B9. Philadelphia Inquirer, Feb. 17, 1891, p. 10; Philadelphia Record, 2/17/1891, p.8.

B10. See B3.

Panic of 1893

C1. Philadelphia Inquirer report on 6/16/1893, p. 5.

C2. Philadelphia Inquirer, 6/20/1893, p. 5; Philadelphia Record, 6/20/1893.

C3. Philadelphia Inquirer, 6/16/1893, p. 5.

C4. Philadelphia Inquirer, 8/8/1893, p.6: "There is very general complaint among the banks in the interior of the State ever the unsatisfactory course pursued by the banks of this city. The banks here not only refuse to send currency into the interior, out the officials decline to commit themselves as to their policy in ease difficulties arise. In other words, the country banks can neither get their cash nor any assurance that money will be sent in case of a run. Such a course as this is not at all likely to disarm apprehensions as to the future. Another matter that has caused general and unfavorable comment is the refusal of the Clearing House to make known the amount of certificates issued. In all other cities the information is cheerfully published, but in Philadelphia the secret is regarded as too awful to be published and is disclosed only to the elect. The only clue as to the amount outstanding is conveyed in the reports to the Comptroller of the Currency under date of July 12 , where an item "other liabilities" is given as $\$ 5,870,000$, whereas the same item on May 4 was $\$ 510,000$. In times like the present secrecy only arouses suspicion, while a plain statement alone will dissipate distrust. The banks have asked much from their depositors, and all they have asked has been cheerfully granted, but surely the banks owe something to the public. No harm has resulted from the publication of the issue of certificates in other cities, and it would puzzle the depositories of the awful secret in Philadelphia finance to tell what harm would result from giving out the information here. The time has come when this matter ought to be made known' further secrecy can only lead to the conclusion that the amount is so large the Clearing House officials do not want it to become known. "

C5. Philadelphia Inquirer, 8/10/1893, p.5.; Philadelphia Bulletin, 8/9/1893, p. 1: "A Third Street banking house displays the sign 'United States gold and currency purchased at a premium.' The firm 
offers $11 / 2$ per cent. premium for gold and currency. It has several large orders for funds which it is undertaking to fill in this way, and it is expected that the premium of $\$ 15$ per thousand will bring cash out of tin boxes where it has been secluded. The person who thus sells his money is paid by a check upon a bank, and upon presentation of the check at the bank he will receive a Clearing House due bill, which he may deposit in his own bank, where it will be credited as cash."

C6. See C7.

C7. Philadelphia Inquirer, 9/6/1893, p. 5.

C8. Philadelphia Inquirer, 11/21/1893: "The Clearing House authorities have restored the publication of the detailed bank statement, which was suspended after June 12. At last reports all but a few of the Clearing House certificates had been canceled, and these maybe retired any day."

C9. Philadelphia Inquirer, 11/21/1893, p.5.; Philadelphia Record, 11/21/1893.

C10. Philadelphia Inquirer, 9/11/1893. The last mentioning of loan certificate issuing: "The banks canceled $\$ 1,075,000$ Clearing House certificates in the week, but $\$ 235,000$ were issued, the net reduction being $\$ 850.000$. There are now $\$ 37,440,000$ of certificates outstanding, but it is expected this amount will be reduced considerably in the present week."

\section{Panic of 1907}

D1. The 1907 crisis spread from NY, as reflected in the Philadelphia Inquirer report on 10/22/1907, p. 1 and the Philadelphia Bulletin report on 10/22/1908, p.1.

D2. Philadelphia Inquirer, 11/5/1907, p.15; Philadelphia Record, 11/5/1907, p.14.

D3. No direct news or announcement. On 11/4/1907 the Philadelphia Inquirer mentioned the "Clearing House's plan of issuing loan certificates," and on 11/5/1907, there is the announcement that "[d]uring the time that Clearing House certificates are outstanding, the Philadelphia National banks following the New York precedent, will issue only a summarized statement." However, there was mention of "The situation in financial circles was helped by the action of the banks in issuing Clearing House certificates and the test companies in paying depositors with checks upon their banks payable through the Clearing House only" on $10 / 29$, but it is not clear whether this news pertains to situations in New York or in Philadelphia.

D4. See D3.

D5. Philadelphia Inquirer, 11/5/1907, p.15: "Pending the arrival of gold imports, money is exceedingly scarce. Indeed, actual currency is very difficult to secure in large amounts in this city. Already it is bringing a premium of from 2 to $4 \%$, and brokers are gathering it up to sell to concerns and manufacturers who have large pay rolls which must be met with cash. If relief does not come 
before the week is over it is likely that cashier's checks for $\$ 5, \$ 10$ and $\$ 20$ will be in circulation. The local bank statement accounts for the scarcity of funds here, showing large decreases in deposits and reserves."

D6. Philadelphia Inquirer, 12/11/1907, p.11 indicated there was a zero currency premium on the street on $12 / 10 / 1907$. But on $1 / 7$, the news reads "There seemed to be an accumulation of buying orders in the stock market at the opening yesterday, which was due largely to the better bank statement published Saturday, and the promise of further ease in the monetary situation, as shown by the elimination of the premium on currency and the prospects of passing away of the Clearing House certificates." This indicates there might have been currency premium by as late as 1/6/1908. In addition, the Philadelphia Record 12/28-12/30 mentioned a decline in currency premium. On $12 / 30$, "...The source of anxiety was clearly indicated by the brisk rebound in stocks at the end of the week, induced by the decisive decline in the premium on currency..."

D7. Philadelphia Inquirer, 1/8/1908, p.11.

D8. Philadelphia Inquirer, 2/11/1908, p.11: "For the first time since Oct 29th the Philadelphia Clearing House Association yesterday issued a detailed statement of the figures of the associated banks, as on Saturday the last of the clearing house certificates were retired."

D9. See D8.

D10. Philadelphia Inquirer, 2/11/1908, p. 11; Philadelphia Record, 2/11/1908, p.12. 
Appendix: Table A1 - -Details for Tables 1 and 2

\begin{tabular}{|c|c|c|c|c|c|c|c|c|c|c|}
\hline & $\mathbf{1}$ & $\mathbf{2}$ & $\mathbf{3}$ & $\mathbf{4}$ & $\mathbf{5}$ & $\mathbf{6}$ & $\mathbf{7}$ & $\mathbf{8}$ & $\mathbf{9}$ \\
\hline $\begin{array}{c}\text { Panic } \\
\text { of: }\end{array}$ & $\begin{array}{c}\text { Panic } \\
\text { start } \\
\text { date }\end{array}$ & $\begin{array}{c}\text { Date of } \\
\text { suspension } \\
\text { of } \\
\text { convertibility }\end{array}$ & $\begin{array}{c}\text { Date CH } \\
\text { stopped } \\
\text { publishing } \\
\text { bank-specific } \\
\text { information }\end{array}$ & $\begin{array}{c}\text { Date of first } \\
\text { CH loan } \\
\text { certificates }\end{array}$ & $\begin{array}{c}\text { First Date at } \\
\text { which } \\
\text { currency } \\
\text { premium is } \\
\text { positive }\end{array}$ & $\begin{array}{c}\text { Date of last } \\
\text { CH loan } \\
\text { certificate } \\
\text { issue }\end{array}$ & $\begin{array}{c}\text { Date of final } \\
\text { cancellation }\end{array}$ & $\begin{array}{c}\text { Date of } \\
\text { resumption } \\
\text { of } \\
\text { convertibility }\end{array}$ & $\begin{array}{c}\text { Date that } \\
\text { individual bank } \\
\text { info starts } \\
\text { being } \\
\text { published again }\end{array}$ & $\begin{array}{c}\text { Date at } \\
\text { which } \\
\text { currency } \\
\text { premium is } \\
\text { zero }\end{array}$ \\
\hline 1873 & A1 & A2 & A3 & A4 & A5 & A6 & A7 & A9 & A10 & A11 \\
\hline 1884 & B1 & B2 & B3 & B4 & B5 & B6 & B7 & B9 & B10 & B11 \\
\hline 1890 & C1 & C2 & C3 & C4 & C5 & C6 & C7 & C9 & C10 & C11 \\
\hline 1893 & D1 & D2 & D3 & D4 & D5 & D6 & D7 & D9 & D10 & D11 \\
\hline 1907 & E1 & E2 & E3 & E4 & E5 & E6 & E7 & E9 & E10 & E11 \\
\hline
\end{tabular}




\section{Appendix B: The check collection process at clearing houses}

The Clearing of Checks at the Clearing House (from Squire (1888)):

Each bank member of the association sends daily to the Clearing House two clerks, one designated as delivery clerk, the other as settling clerk, the deliver clerk to distribute the exchanges, the settling clerk to receive the exchanges from the deliver clerks. They assemble a little before ten o'clock, at which hour (promptly) the operation of clearing begins.

Upon entry of the settling clerk, he furnishes the Manager with a credit ticket, showing the amount of exchanges brought by his bank. At ten o'clock the manager takes his position on the platform with his Assistant Manager and staff, one of whom is a Proof Clerk, who has a Proof Sheet, upon which he enters the Credit Tickets. After the exchanges are made, each Settling Clerk sends the result of the exchanges of his bank on tickets called Debit Tickets, to the Proof Clerk, who enters them on his sheet. After footing the total of the Proof Sheet the amount brought (Credit Tickets), and the amount received (Debit Tickets), should be the same and the resulting balances should also prove.

At the tap of a gong, the Settling Clerks occupy their respective desks, with their settling sheets before them, upon which, opposite the names of the various banks of the association, is entered the amounts brought in exchanges against each bank. The Delivery Clerks with the exchanges in boxes arranged in consecutive order for delivery, in front of their desks, have a receipt list (or as it is termed, Delivery Clerk's Statement), with the amount of exchanges opposite the name of each bank set down in delivery order.

The manager upon the first stroke of the gong, surveys the assembled clerks to see that all are present. The second stroke is a signal for the clearings to begin.

Each Delivery Clerk advances to the next desk at which he delivers the exchanges and receipt list; each Settling Clerk upon receipt of the exchange, receipts for it, and enters it on his settling sheet opposite the name of the bank from which he received it; thus the exchanges continues until every bank has been visited, and the Delivery Clerk has returned to the desk occupied by his bank. ... In about ten minutes the exchanges have been made, and the Settling Clerk has entered on his settling sheet, opposite the name of the banks, the various exchanges he has received, thus having a record on his sheet, of the amount brought, and the amount received from each bank. ... he foots up the aggregate he has received from various banks, and then makes a ticket called Debit Ticket, which is sent to the Proof Clerk on the platform. . . . The differences are generally announced in about half an hour. . By three o'clock the settlements of the transactions are completed.... (p. 8-14) 


\section{Weekly City Bank Sintements.}

An Act. seluting to Incorpornted Banks, Banking Associntinus, and Indivilual Bnnkers, locuted and doing businees in the City uf Now-York.

The People of the State of New. York represented in Senate and Assimbly. do cnact as fullows:

SFction 1. In adfition to the quarterly stateinents now required hy law to bo male to the Superintendent of the Bunking Department, by Incorporated Banks, Banking Assosiutions and Individual Bankers in this State, every incorporated bask, hanking association, or inditidual bunker, located and doing business in the City of New.York, shall publish, or cause to be published, oul the norning of every Tuesday, in a newspanor printed in said City, to be designated by the Superintendent, a stutement under the onth of the l'resident or Cashicr, showing the true condition of the bunk, banking nssosinfion, or individual tranker, making such stutement on the subruing of each dny of the werk next preceding the date of such stulement in respect on the following items and merticulurs to wit: A vermegnent of loans and discounts, sjut cie, defosits, and circulutinn.

SEC. 2. Sucli statement shall he published at the expense of the bank; banking ussociation, or individual baraker, making the same, and if any bank, bunking assoration. or individual banker, shall neplect or rofuse to wake the stutement reguired in the first section of this act, for two successivo Tuesdays, it shall forfeit its charter, (if an illcorporated hank, and its privileges as a fankil, a assoriation or individunl hanker; and overy such bauk, banking associntion, or individual banker, mny be woceded against, and its affairs closed, in any manner unw lequired by law, in case of an insolvent bank or banking associntion. The terms "banking nssuciation" and "individual banks," as used in this nct, shall be deened to "lply only to such hunking ussociations and individual hanks ss are or may be organized under the nct of April 18, 1838, und tho soveral ucts ajuendatory thereto.

SEC. 3. This act shall take effuct August first, one thourand eight hundred and fifty-threc. 


\section{Appendix D: The Effect of a Currency Premium on Gold Points and Gold Imports}

The analysis of gold export and gold import points describes "average" circumstances. The points are a function of the relevant interest rate, the costs of shipping, the cost of insuring the cargo (gold), etc.

The fluctuations of such costs during brief time intervals were minimal in contrast to the effect of a currency premium on the profitability of gold imports into the U.S. The panic periods were of short duration and the currency premium varied over time. For clarity, we illustrate the effect on gold import points of a 1 percent currency premium and a 4 percent currency premium.

EXAMPLE: The US Dollar UK Pound Exchange Rate ${ }^{36}$

Mint parity value for the U.S. dollar per UK pound exchange rate was:

$\$ 4.86656$

Gold import point (below this value, it was profitable to import gold into U.S.):

Gold export point (exchange rates above this value, profitable to export gold):

Suppose the market exchange rate is $\$ 4.82$ (per pound), which is below the gold import point. Then, the gold importer would pay $\$ 4.82$ in dollars for a British pound, take it to the Chancellor of the Exchequer for $\$ 4.86656$ worth of gold, and ship that gold to the United States, making a profit of:

$\$ 4.86656-\$ 4.82=\$ 0.04656$, or less than 5 cents, which is a $0.966 \%$ return on the $\$ 4.82$ investment.

Currency premium of 4 percent:

Mint parity: $\quad \$ 4.86656 *(1+0.04)=$

Gold import point: $\quad \$ 4.835 *(1+0.04)=$ 5.028

Gold export point: $\quad \$ 4.899 *(1.04)=$ 5.095

How does this affect the gold import/export points? The purchase of gold at any value below the adjusted gold import point (adjusted for the value of the gold in term of US dollars in the New York City money market) will provide a profit opportunity to the gold importer. Notice that the adjusted gold import point of $\$ 5.028$ is above the normal gold EXPORT point (\$4.899).

Currency premium of 1 percent:

Mint parity: $\quad \$ 4.86656 *(1+0.01)=$

$\$ 4.915$

Gold import point: $\quad \$ 4.835 *(1+0.01)=$

4.883

Gold export point: $\quad \$ 4.899 *(1.01)=$

4.948

\footnotetext{
${ }^{36}$ Coleman (2007) emphasizes that the tri-party relationships among leading European nations effectively eliminated this kind of arbitrage trading between the US and the UK by 1905 . Hence, the example is not meant to mimic the actual transactions in that period. Rather, it uses as convention the US UK transactions as a pedagogic device.
} 


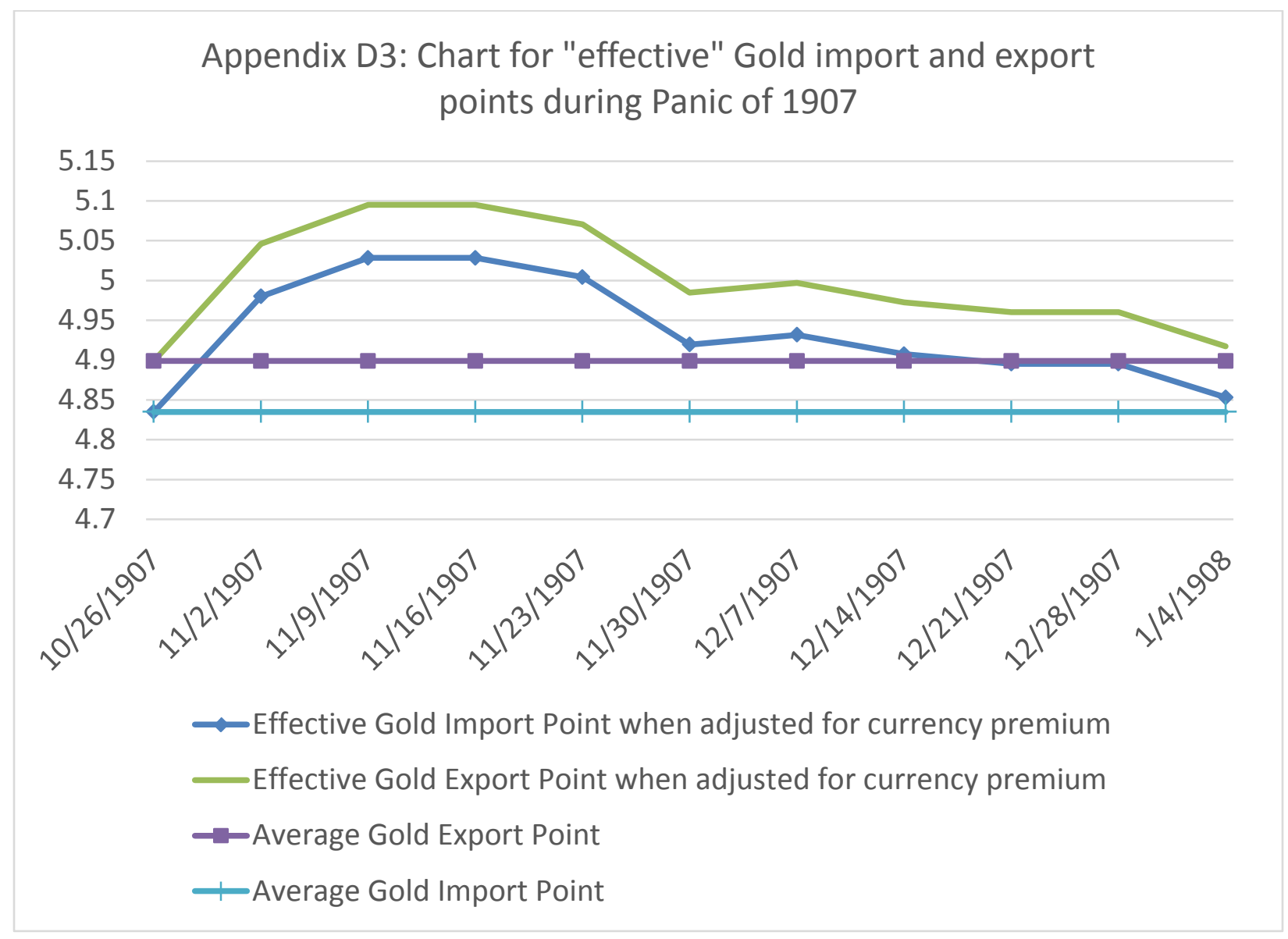

Any market exchange rate below the effective gold import point (blue line with diamond markings) would make gold imports into the U.S. during the crisis period profitable. The most notable aspect of this mechanism is that during a crisis that involves a currency premium, market exchange rates that would normally trigger gold exports were instead consistent with gold imports. At a 4 percent currency premium, any exchange rate below $\$ 5.028$ offers a profit opportunity for the import of gold.

In the "adjusted" gold point example, the gold importer pays say, $\$ 4.86656$ for a UK pound - the mint parity value - exchanges that pound for gold, ships the gold to the U.S., exchanges the gold for $\$ 4.86656$ in dollars and then sells the dollars for $\$ 4.86656^{*}$ (1+currency premium). The "profit" in the two currency premium cases comes from the ability to sell a dollar of gold for a percentage premium.

$\$ 4.86656 *(1+0.04)-\$ 4.86656=\$ 5.061-\$ 4.86656=\$ 0.1944$ or nearly 20 cents (a $4 \%$ return).

The returns are not "annual percentage rates" but returns that accrue over a span of a few weeks for the transactions to take place and for the gold to get shipped overseas.

Note that the profits from these transactions would clearly be altered by the level of the market interest rates. But the example and the chart using 1907 data demonstrates that the mechanism generates substantial profit opportunities from gold importation. 


\section{Appendix E: Currency Composition in the United States 1860-1914}

The currency supply of the United States from 1860-1914 was comprised of various forms of payment media. In normal periods, all forms of coinage and currency traded at par during day to day exchanges. The variegated currency supply in the U.S. is important for this paper because the New York Clearing House held rigid standards for what it would consider as "final payment" media. This is only an outline of the acceptable media and not a rigorous analysis of the reasons for their choices.

During the Panic of 1873, the New York Clearing House considered only legal tender ("greenbacks") as acceptable as a final payment medium. After 1879 and the return to the gold standard, gold coin (specie) and legal tender could be used for final payment at the New York Clearing House. During the gold standard era, greenbacks were redeemed for gold by the U.S. Treasury, despite the fact that the Treasury had the option to redeem U.S. notes with gold or silver. The Gold Standard Act of 1900 made the redemption in gold mandatory.

It is notable that national bank notes were never accepted for final payment at the New York Clearing House. Neither were silver certificates, which became a sizable component of the hand to hand money supply in the 1880 s and 1890 s.

In the chart below, the first four components of the currency supply - gold coin, gold certificates, U.S. notes, and other US Currency- comprised the supply of currency for what the New York Clearing House would consider final payment. The "legal tender" components are indicated as shades of green and shades of orange or yellow in the chart.

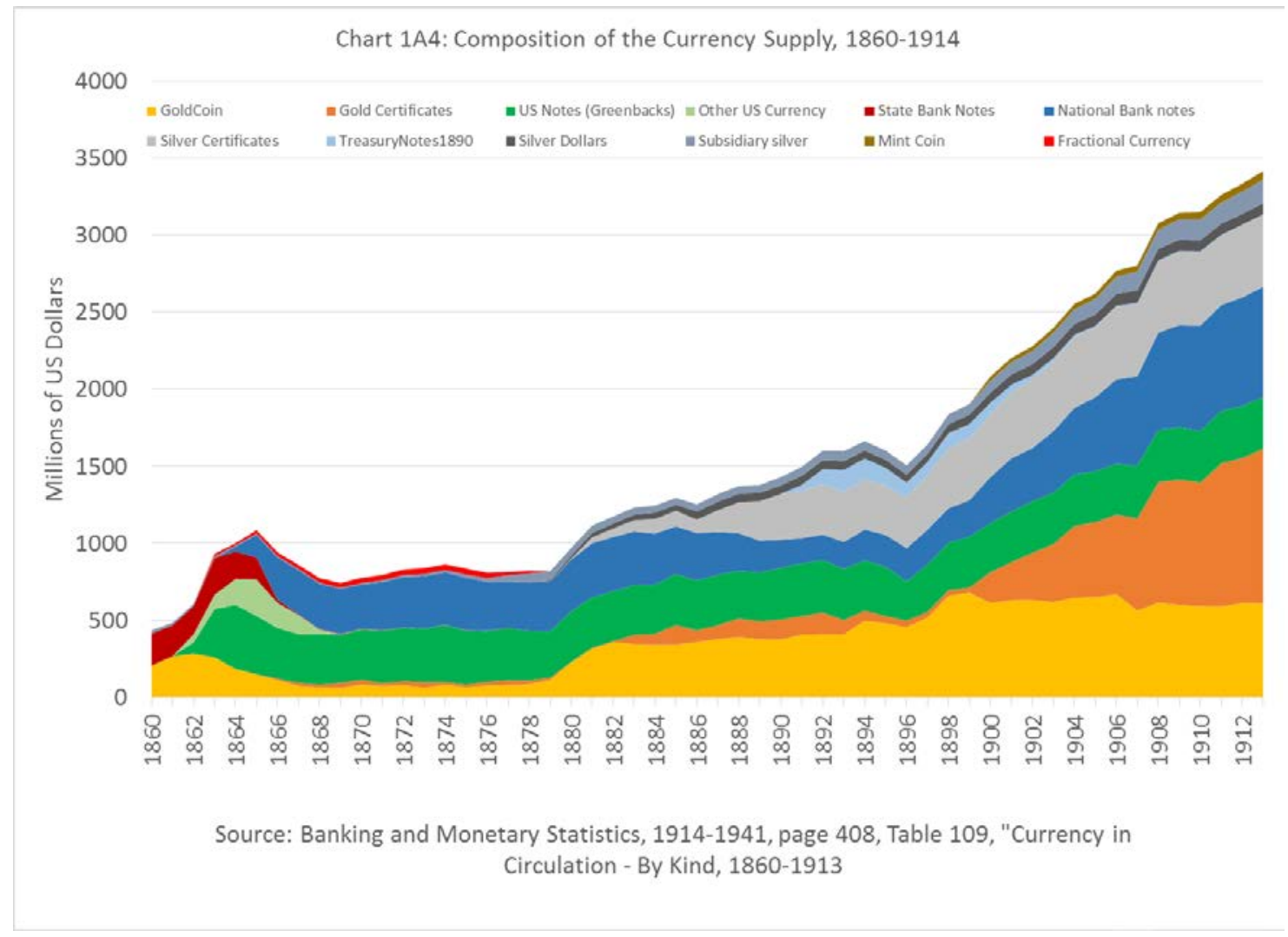




\section{References}

\section{Primary Sources}

Attorney General of the State of New York, Annual Reports, various years.

The Bankers' Magazine, various issues.

Commercial and Financial Chronicle, various issues.

Forum, various issues.

Government Accountability Office (GAO), U.S. (2010), Troubled Asset Relief Program: Bank Stress Test Offers Lessons as Regulators Take Further Actions to Strengthen Supervisory Oversight GAO-10861.

New York Clearing House Association, Minutes, various.

New York Clearing House Association (1903), Constitution of the New York Clearing House Association, with Amendments (Arthur Mountain \& Co.).

New York Clearing House Association (1873), Report to the New York Clearing House Association of a Committee Upon Reforms in the Banking Business (W.H. Arthur \& Company' New York).

New York Daily Times, various issues.

New York Times, various issues.

New York Times Financial Affairs, various issues.

New York Tribune, various issues.

New York Sun, various issues.

Philadelphia Bulletin, various issues.

Philadelphia Inquirer, various issues.

Philadelphia Record, various issues.

Superintendent of the Bank Department of the State of New York, Annual Reports, various years.

U.S. Comptroller of the Currency (1891), Annual Report (Washington DC: Government Printing Office).

U.S. Comptroller of the Currency (1907), Annual Report (Washington DC: Government Printing Office).

U.S. Comptroller of the Currency (1908), Annual Report (Washington DC: Government Printing Office). 
Wall Street Journal, various issues.

\section{Secondary Sources}

Acheson, Graeme, Charles Hickson, and John Turner (2010), “Does Limited Liability Matter? Evidence from Nineteenth century British Banking," Review of Law and Economics 6, 247-273.

Almeida, Heitor and Thomas Philippon, (2007), "The Risk-Adjusted Cost of Financial Distress", Journal of Finance 62, pp. 2557-2586.

Anbil, Sriya (2014), “Managing Stigma during a Crisis," Yale working paper.

Andrew, A. Piatt (1910), Statistics of Banks and Banking in the United States (National Monetary Commission: Washington D.C.)

Andrew, A. Piatt (1908a), "Substitutes for Cash in the Panic of 1907," Quarterly Journal of Economics 22 (2): 290-99.

Andrew, A. Piatt (1908b), "Hoarding in the Panic of 1907," Quarterly Journal of Economics 22 (4): 497516.

Appel, Ian and Caroline Fohlin (2010), "'Shooting the Messenger?' The Impact of Short Sale Bans in Times of Crisis," Emory University, working paper.

Armantier, Olivier, Eric Ghysels, Asani Sarkar, Jeffrey Shrader (2011), "Stigma in Financial Markets: Evidence from Liquidity Auctions and Discount Window Borrowing during the Crisis," New York Federal Reserve Bank, working paper.

Babson, Roger (1908), "How the Amount of Money in Circulation Affects the Merchant," The Ticker Vol. I, No. 5 (March), 14-17.

Bailey, Dudley (1890), The Clearing House System (New York: Homans).

Barnett, Robert (1884), "On the Action of the New York Clearing House Association during the Recent Crisis," Journal of the Institute of Bankers 4, 481-503.

Bayazitova, Dinara and Anil Shivdasani (2012), "Assessing TARP," Review of Financial Studies 25, 377407.

Bayles, W. Harrison (1917), A History of the Origin and Development of Banks and Banking, Chapter 14 reprinted in McMaster's Commercial Cases, Vol. 20 (The McMaster Company; New York).

Beber, Alessandro and Marco (2013), "Short-Selling Bans Around the World: Evidence from the 2007-09 Crisis," Journal of Finance 68, 343-381.

Bagehot, Walter (1873), Lombard Street: A Description of the Money Market (Henry S. King; London). 
Bernanke, Ben (2014a), "Central Banking after the Great Recession: Lessons Learned and Challenges Ahead: A Discussion with Federal Reserve Chairman Ben Bernanke on the Fed's 100th Anniversary," Brookings Institution (January).

Bernanke, Ben (2014b, January 3), “The Federal Reserve: Looking Back, Looking Forward." http://www.federalreserve.gov/newsevents/speech/bernanke20140103a.htm

Bernanke, Ben (2009), The Federal Reserve's Balance Sheet: An Update," Speech at the Federal Reserve Conference on Key Developments in Monetary Policy, Washington D.C.

Bluedorn, John and Haelim Park (2015), "Stopping Contagion with Bailouts: Micro-Evidence from Pennsylvania Bank Networks during the Panic of 1884," working paper.

Bolles, Albert (1903), Practical Banking, Eleventh Edition (Levey Bro's \& Co.).

Calomiris, Charles, and Gary Gorton. 1991. "The Origins of Banking Panics: Models, Facts, and Bank Regulation." In Financial Markets and Financial Crises, ed. Glenn Hubbard. Chicago: University of Chicago Press: 93-163.

Coleman, Andrew (2007) "The Pitfalls of Estimating Transactions Costs from Price Data: Evidence from Trans-Atlantic Gold-point Arbitrage, 1886-1905." Explorations in Economic History 44: 387-410.

Camp, William (1892), “The New York Clearing House," North American Review 154, 684-690.

Cannon, James Graham (1910a), Clearing Houses (Washington, DC: Government Printing Office).

Cannon, James Graham (1910b), "Clearing House Loan Certificates and Substitutes for Money Used During the Panic of 1907." Speech delivered at the Finance Forum, New York City, March 30, 1910 (The Trow Press: New York).

Clews, Henry (1888), Twenty-eight Years in Wall Street (Irving Publishing; New York.

Curtis, Charles (1898), "Clearing House Loan Certificates, How Issued and Why," The Yale Review 6 (The Tuttle, Morehouse \& Taylor Press: London)(November), p. 251-266.

Dang, Tri Vi, Gary Gorton and Bengt Holmström (2013), "Ignorance, Debt and Financial Crises," Yale, working paper.

Draghi, Mario (2013, May 23), "Building Stability and Sustained Prosperity in Europe," Speech at the event entitled "The Future of Europe in the Global Economy," hosted by the City of London. http://www.bis.org/review/r130524a.pdf?frames=0 .

Geithner, Timothy (2014), Stress Test: Reflections on Financial Crises (Crown Publishers; New Yrok).

Gibbons, J.S. (1859), The Banks of New York, their Dealers, the Clearing House, and the Panic of 1857 (D. Appleton \& Co.; New York). 
Gilpin, William and Henry Wallace (1904), New York Clearing House Association, 1854-1905 (Moses King; New York).

Gorton, Gary (1984), "Private Bank Clearinghouses and the Origins of Central Banking," Business Review-Federal Reserve Bank of Philadelphia, January/February, 3-12.

Gorton, Gary (1985a), "Bank Suspension of Convertibility," Journal of Monetary Economics 15, 177-93.

Gorton, Gary (1985b), "Clearinghouses and the Origin of Central Banking in the United States," Journal of Economic History 45 (2): 277-83.

Gorton, Gary (1988), "Banking Panics and Business Cycles," Oxford Economic Papers 40(4), 751-81.

Gary, Gorton (1999), “Pricing Free Bank Notes," Journal of Monetary Economics 44, 33-64.

Gorton, Gary (1996), "Reputation Formation in Early Bank Note Markets," Journal of Political Economy 104(2), 346-397.

Gorton, Gary (2012), Misunderstanding Financial Crises: Why We Don't See Them Coming (Oxford University Press; 2012).

Gorton, Gary (2013), "The Development of Opacity in U.S. Banking," Yale Journal of Regulation, forthcoming.

Gorton, Gary (2014), "Stress for Success: A Review of Timothy Geithner's Financial Crisis Memoir," Journal of Economic Literature, forthcoming.

Gorton, Gary and Lixin Huang (2006), "Banking Panics and Endogenous Coalition Formation," with Lixin Huang, Journal of Monetary Economics, Vol. 53 (7): 1613-1629.

Gorton, Gary, and Don Mullineaux (1987), "The Joint Production of Confidence: Endogenous Regulation and Nineteenth Century Commercial Bank Clearinghouses," Journal of Money, Credit, and Banking 19(4), 458-68.

Gorton, Gary and George Pennacchi (1990), "Financial Intermediation and Liquidity Creation," Journal of Finance 45(1), 49-72.

Gorton, Gary and Guillermo Ordoñez (2014), "Collateral Crises," American Economic Review 104(2), 343378.

Gorton, Gary and Ellis Tallman (2015), "Too-Big-To-Fail before the Fed," working paper.

Gruenewald, Serainan, Alexander Wagner, and Rolf Weber (2010), "Emergency Short-Selling Restrictions in the Course of the Financial Crisis," University of Zurich working paper. 
James, John and David F. Weiman (2010), "From Drafts to Checks: The Evolution of Correspondent Banking Networks and the Formation of the Modern U.S. Payments System, 1850-1914,"Journal of Money, Credit, and Banking, Volume 42, Issue 2-3, pages 237-265.

Kane, Thomas (1922), The Romance and Tragedy of Banking (The Bankers Publishing Company, New York).

Kemmerer, Edwin R. (1910) Seasonal Variations in the Relative Demand for Money and Capital in the United States, Washington: Government Printing Office.

King, Mervyn (2010, October 25), "Banking-from Bagehot to Basel, and Back Again," Speech at the Second Bagehot Lecture, Buttonwood Gathering, New York. http://www.bis.org/review/r101028a.pdf?frames=0

Kniffin, William (1916), The Practical Work of a Bank (The Bankers Publishing Company: New York).

Laughlin, J. Laurence (1912), Banking Reform (The National Citizens' League: Chicago).

Macey, Jonathan and Geoffrey Miller (1992), "Double Liability of Bank Shareholders: History and Implications," Wake Forest Law Review 27, 31-62.

Marquis, Ralph and Frank Smith (1937)," Double Liability for Bank Stock," American Economic Review 27, 490-502.

Moen, Jon, and Ellis Tallman (1992), "The Bank Panic of 1907: The Role of Trust Companies," Journal of Economic History 52 (3), 611-30.

Moen, Jon, and Ellis Tallman, (2000), "Clearinghouse Membership and Deposit Contraction during the Panic of 1907," Journal of Economic History 60, 145-63.

Moen, Jon and Ellis Tallman (2015), "Close but not a Central Bank: The New York Clearing House and Issues of Clearing House Loan Certificates," in Current Policy Under the Lens of Economic History, Edited by Owen Humpage (Cambridge University Press: New York), March.

Moody's (July 2011), "Europe Misses Again on Bank Stress Test," Moody's Analytics, Regional Financial Review, 11-15.

Noyes, Alexander (1894), "The Banks and the Panic of 1893," Political Science Quarterly 9 (1), 12-30.

Noyes, Alexander (1909), "A Year after the Panic of 1907," Quarterly Journal of Economics 23, 185-212.

Noyes, Alexander (1907), "The Clearing House Committee," The Independent LXIII, 1029-1033.

Officer, Lawrence (2006), "Gold Standard," http://eh.net/encyclopedia/gold-standard/ , edited by Robert Whaples. 
Officer, Lawrence (1986), "The Efficiency of the Dollar-Sterling Gold Standard, 1890-1908," Journal of Political Economy 94, 1038-1073.

O'Sullivan, Mary (2007), "The Expansion of the U.S. Stock Market, 1885-1939: Historical Facts and Theoretical Fashions," Enterprise and Society 8, 489-542.

Redlich, Fritz. (1947) The Molding of American Banking Banking. New York: Hafner Publishing.

Rodgers, Mary Tone and James E. Payne (2014), "How the Bank of France Changed U.S. Equity Expectations and Ended the Panic of 1907," Journal of Economic History 74, 420-448.

Rodgers, Mary Tone and Berry Wilson (2011), "Systemic Risk, Missing Gold Flows, and the Panic of 1907," Quarterly Journal of Austrian Economics 14, 158-187.

Schwert, G. William. (1990) "Indexes of United States Stock Prices from 1802 to 1987." Journal of Business, 63, July, 399-426.

Silber, William (2007), When Washington Shut Down: The Great Financial Crisis of 1914 and the Origins of America's Monetary Supremacy (Princeton: Princeton University Press).

Smith, Gordon (1908), "Clearing-House Examinations," The Bankers' Magazine LXXVI (1908) (The Bankers Publishing Co.), 177-178.

Sprague, O. M. W. (1908), "The American Crisis of 1907." Economic Journal 18 (71): 353-72.

Sprague, O. M. W. (1910), History of Crises under the National Banking System. Senate Document 538. Washington DC: Government Printing Office.

Squire, Newton (1888), The New York Clearing House, its Methods and Systems, and a Description of the London Clearing House, with Valuable Statistics and Other Information (Arthur \& Bonnell; New York City).

Stevens, Albert C. (1894), "Analysis of the Phenomena of the Panic in the United States in 1893." Quarterly Journal of Economics 8 (2): 117-48.

Swanson, William Walker. (1908a), "The Crisis of 1860 and the First Issue of Clearing-House Certificates: I." Journal of Political Economy 16 (2): 65-75.

Swanson, William Walker. (1908b), "The Crisis of 1860 and the First Issue of Clearing-House Certificates: II." Journal of Political Economy 16 (4): 212-26.

Tallman, Ellis W. (2013), "The Panic of 1907." in The Handbook of Major Events in Economic History, edited by Randall E. Parker and Robert Whaples. New York: Routledge. 
Tallman, Ellis W. and Jon R. Moen (2014) "The Transmission of the Financial Crisis in 1907: An Empirical Investigation." Unpublished manuscript, (previous version available on the web at: http://dev3.cepr.org/meets/wkcn/1/1730/papers/MoenFinal.pdf).

Tallman, Ellis and Jon Moen (2012), "Liquidity Creation Without a Central Bank: Clearing House Loan Certificates in the Banking Panic of 1907," Journal of Financial Stability, 8, 277- 291.

Thrall, Jerome (1916), The Clearing House (American Bankers Association; New York).

Timberlake, Richard (1984), "The Central Banking Role of Clearinghouse Associations," Journal of Money, Credit and Banking 16, 1-15.

Wicker, Elmus (2000), Banking Panics of the Gilded Age (Cambridge, UK: Cambridge University Press).

Xie, Lei (2012), "The Seasons of Money: ABS/MBS Issuance and the Convenience Yield," working paper. 


\begin{tabular}{|c|c|c|c|}
\hline Panic & Date of Exam & $\begin{array}{l}\text { CH } \\
\text { Member? }\end{array}$ & Some Details \\
\hline \multicolumn{4}{|l|}{ Panic of 1873} \\
\hline National Bank of Commonwealth & Oct. 8, 1873 & Yes & $\begin{array}{l}\text { CH examination carried out at the request of the bank's president who } \\
\text { deems receiver's report to be incorrect. NYT, Sept. 20, 22, 23, 24, 1987; } \\
\text { NYT Oct. } 7,13,1873 \text {. }\end{array}$ \\
\hline Three state banks & Oct. 1, 1873 & No & CH Minutes, March 11, 1854-Dec. 10, 1894, Vol. 1.1, no pagination. \\
\hline \multicolumn{4}{|l|}{ Panic of 1884} \\
\hline Metropolitan National Bank & May 14, 1884 & Yes & $\begin{array}{l}\mathrm{CH} \text { Investigating committee examines bank; issues notice that based on } \\
\text { the examination } \mathrm{CH} \text { will lend the bank money. Bank reopens on May } 15 .\end{array}$ \\
\hline \multicolumn{4}{|l|}{ Panic of 1890} \\
\hline North River Bank & Nov. 13, 1890 & Yes & $\begin{array}{l}\text { North River Bank was forced to close by state bank examiners on Nov. } \\
12,1890 \text {. The suspension was not expected, so the } \mathrm{CH} \text { committee went } \\
\text { to the bank to investigate. They were "exceedingly doubtful" that the } \\
\text { bank would ever open again. NYT. } 11 / 14 / 90, \text { p. } 5 \text {. }\end{array}$ \\
\hline Bank of North America & Nov. 14, 1890 & Yes & $\begin{array}{l}\mathrm{CH} \text { committee examines the Bank of North America filed a brief report, } \\
\text { certifying that "its capital is intact, it has a large surplus, and its means } \\
\text { are ample to meet all its obligations". NYT, } 11 / 15 / 90, \text { p. } 8 \text {. }\end{array}$ \\
\hline Mechanics \& Traders' Bank & Nov. 15, 1890 & Yes & $\begin{array}{l}\text { CH committee examined Mechanics \& Traders Bank, certifying that "its } \\
\text { capital is intact. The bank has a considerable surplus and is fully able to } \\
\text { meet all its obligations." NYT, } 11 / 16 / 90, \text { p. } 2 \text {. }\end{array}$ \\
\hline \multicolumn{4}{|l|}{ Panic of 1893} \\
\hline Madison Square Bank & August 9, 1873 & No & $\begin{array}{l}\text { Madison Bank takes its books to the Clearing House in an attempt to } \\
\text { prove its soundness. NYT, p. } 5 \text {. CH Committee visits bank to examine, } \\
\text { but makes no statement about results. Unofficial statement by an } \\
\text { officer present says there is a deficiency. NYT, p.5. }\end{array}$ \\
\hline National Bank of Deposit & May 22, 1893 & No & $\begin{array}{l}\mathrm{CH} \text { member Seaboard National Bank refuses to act as } \mathrm{CH} \text { agent for } \\
\text { National Bank of Deposit. CH Committee examines National and } \\
\text { recommends bank go into liquidation (NYT, May 23, 1893, p. 1). }\end{array}$ \\
\hline
\end{tabular}




\begin{tabular}{|l|c|c|l|}
\hline Panic of $\mathbf{1 9 0 7}$ & & \\
\hline Mercantile National Bank & Oct. 17, 1907 & Yes & $\begin{array}{l}\text { CH exams bank issues statement saying "the examination results show } \\
\text { the bank to be perfectly solvent and be able to meet all its } \\
\text { indebtedness" (NYT, Oct. 18, 1907, p. 1). }\end{array}$ \\
\hline New Amsterdam National Bank & Oct. 20, 1907 & Yes & $\begin{array}{l}\text { CH Committee examines bank finds them solvent and agrees to make } \\
\text { emergency loan. NYT, Oct. 21, 1907, p. 1. }\end{array}$ \\
\hline National Bank of North America & Oct. 20, 1907 & Yes & $\begin{array}{l}\text { CH Committee examines bank finds them solvent and agrees to make } \\
\text { emergency loan. NYT, Oct. 21, 1907, p. 1. }\end{array}$ \\
\hline
\end{tabular}




\begin{tabular}{|c|c|c|c|}
\hline Panic & Date of Exam & $\begin{array}{l}\text { CH } \\
\text { Member? }\end{array}$ & Some Details \\
\hline \multicolumn{4}{|l|}{ Panic of 1873} \\
\hline National Bank of Commonwealth & Sept. 22, 1873 & Yes & $\begin{array}{l}\text { Government bank examiners examine bank, find "nothing startling". NYT, } \\
\text { Sept. } 23 \text { and } 24,1873, \text { p. } 1 \text {. Bank refuses to accept examination report and } \\
\text { requests that } \mathrm{CH} \text { examine the bank. CH agrees with government examiner } \\
\text { NYT, Oct. } 14,1873, \text { p. } 5 \text {. }\end{array}$ \\
\hline \multicolumn{4}{|l|}{ Panic of 1884} \\
\hline Marine National Bank & May 6, 1884 & Yes & $\begin{array}{l}\text { National bank examiner arrives at the Marine Bank and begins his } \\
\text { investigation (WSJ, May 6, 1884, p. 1). On May 7, the CH suspends the } \\
\text { bank for an indefinite period (NYT, May 7, 1884, p. 1). Bank closes on May } \\
14 \text { (WSJ, May 14, p. 1). }\end{array}$ \\
\hline Metropolitan National Bank & May 14, 1884 & Yes & $\begin{array}{l}\text { Receiver appointed May } 13 \text { (NYT, May 14, p. 1). National bank examiner } \\
\text { takes possession of the bank's property on May } 14 \text { (NYT, May 15, p. 1). } \\
\text { National bank examiner announces on May } 15 \text { that the bank's capital is } \\
\text { unimpaired. Bank resumes payments (NYT, May 16, p. 1). Bank starts } \\
\text { voluntary liquidation proceedings on November 18, 1884. }\end{array}$ \\
\hline Second National Bank & May 14, 1884 & Yes & $\begin{array}{l}\text { National bank examiner announces that he is "satisfied that [the Second } \\
\text { National Bank] is in a perfectly sound and solvent condition" (NYT, May 15, } \\
\text { p. 5). }\end{array}$ \\
\hline Atlantic State Bank & May 14, 1884 & No & $\begin{array}{l}\text { The Atlantic State Bank was the Brooklyn correspondent of the Metropolitan } \\
\text { National Bank. When the Metropolitan suspended payments, the Atlantic } \\
\text { closed shortly after on May } 14 \text { (NYT, May 15, p. 1). State bank examiners } \\
\text { complete exam on May } 16 \text { (NYT, May 17, p. 1). Bank does not open. May } \\
21 \text { state bank superintendent declares bank insolvent (NYT, May 22, p. 8). }\end{array}$ \\
\hline \multicolumn{4}{|l|}{ Panic of 1890} \\
\hline North River Bank & Nov. 12,1890 & Yes & $\begin{array}{l}\text { North River Bank forced to close by state bank examiner. State bank } \\
\text { examiners begin their examination. CH also examines bank and is } \\
\text { "exceedingly doubtful" it will reopen (NYT, Nov. 13, p. 1). On Nov. } 13 \text { the } \\
\text { CH refuses to issue loan certificates; regulators take possession of bank } \\
\text { (NYT, 14, p. 1). }\end{array}$ \\
\hline
\end{tabular}




\begin{tabular}{|c|c|c|c|}
\hline \multicolumn{4}{|l|}{ Panic of 1893} \\
\hline Canal Street Bank & June 6,1893 & No & $\begin{array}{l}\text { State bank examiners start examination (NYT, June } 7, \text { p. 9) and on June } 8 \\
\text { announce that the bank would not be allowed "to continue or resume } \\
\text { business" (NYT, June 9, p. 8). }\end{array}$ \\
\hline \multicolumn{4}{|r|}{ ( } \\
\hline $\begin{array}{l}\text { Hamilton Bank; Twelfth Ward } \\
\text { Bank }\end{array}$ & Oct. 24, 1907 & No & $\begin{array}{l}\text { Mercantile announces that it will no longer clear for these banks (Wicker, } \\
\text { p. 90). Oct. 19: Bank examiners declare these banks solvent, but they } \\
\text { remain suspended (NYT, Oct. } 25,1907, \text { p. 5). }\end{array}$ \\
\hline Knickerbocker Trust & Oct. 21,1907 & No & $\begin{array}{l}\text { National Bank of Commerce announces it will no longer clear from } \\
\text { Knickerbocker (NYT, Oct. 22, 1907, p. 1). CH rejects Knickerbocker's } \\
\text { request for a loan (NYT, Wicker, p. 91). Regulators name receivers to take } \\
\text { over bank (NYT, Nov. 1, 1907, p. 2). }\end{array}$ \\
\hline Trust Company of America & Oct. $22-$ Nov. 1 & No & After experiencing runs, trust is examined several times, closes. \\
\hline
\end{tabular}




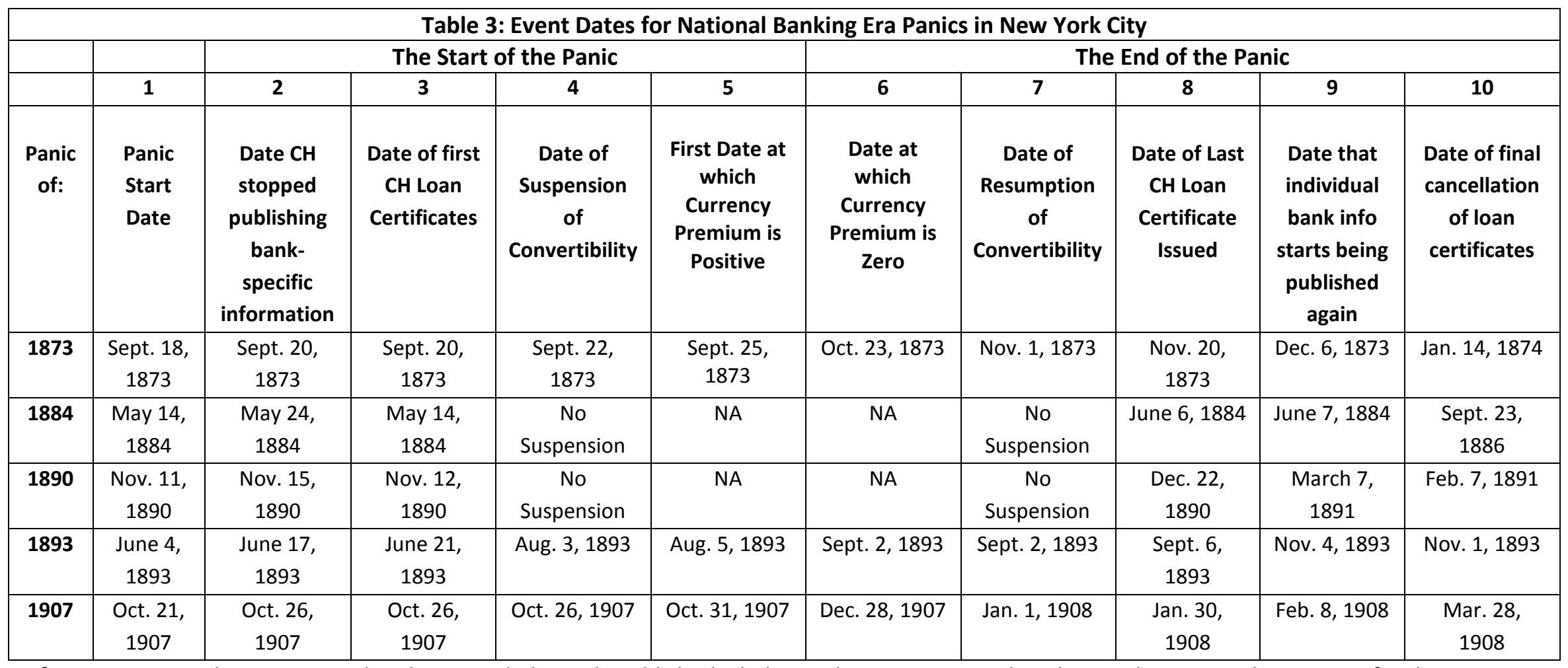

[Note: In 1884, the Commercial and Financial Chronicle published a balance sheet on May 31, but the numbers were the same as for the May 24 balance sheet.] 


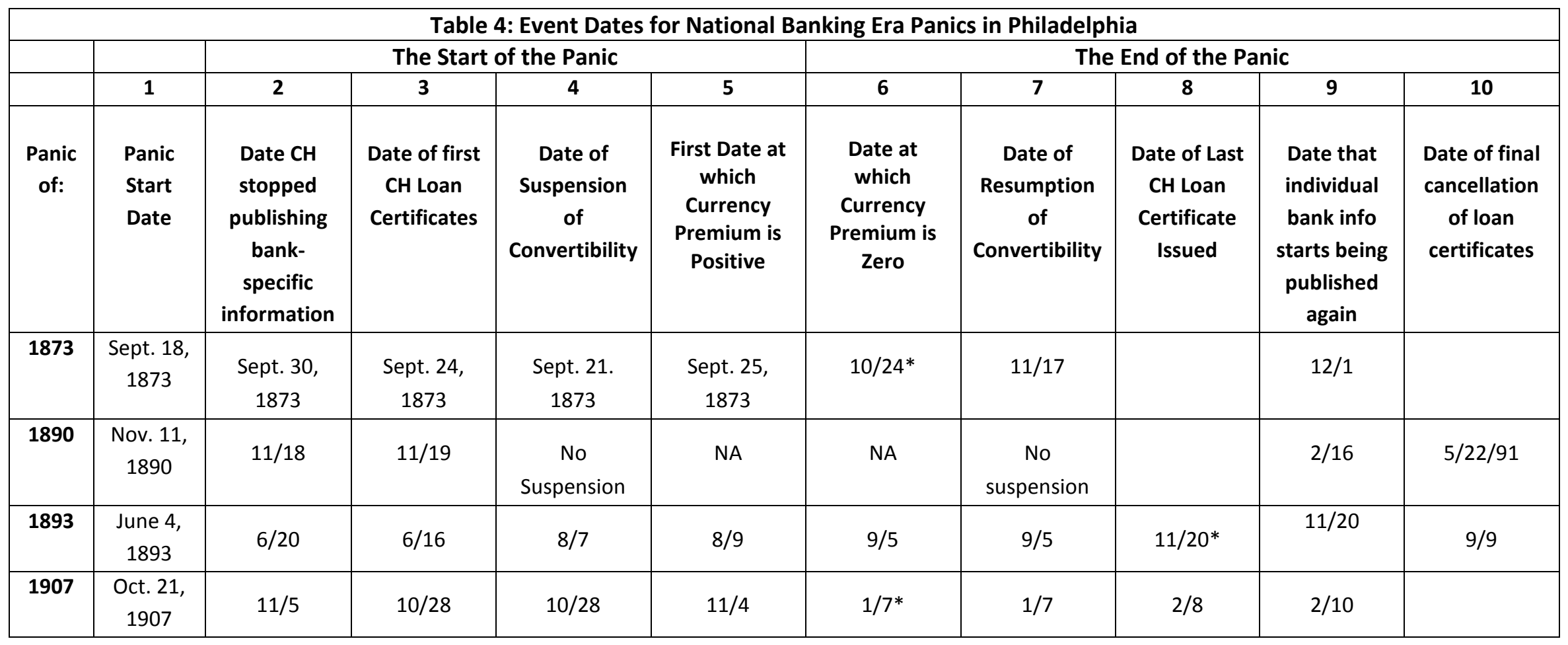




\begin{tabular}{|c|c|c|c|c|c|c|c|c|c|}
\hline \multicolumn{10}{|c|}{ Table 5: New York Financial Market Indicators of Distress and Monetary Quantities } \\
\hline & & & & & & & & & \\
\hline \multirow[t]{3}{*}{ Week } & \multirow[t]{3}{*}{ Week ending: } & \multicolumn{2}{|c|}{ Currency Premium } & \multicolumn{2}{|c|}{$\begin{array}{c}\text { Call Money } \\
\text { Rate }\end{array}$} & $\begin{array}{l}\text { Net Gold } \\
\text { Imports }\end{array}$ & $\begin{array}{l}\text { NYCH Loan } \\
\text { Certificates }\end{array}$ & $\begin{array}{c}\text { Reserve } \\
\text { Deficit }\end{array}$ & \\
\hline & & \multicolumn{7}{|c|}{ New York City } & \\
\hline & & low & high & low & high & Accumulated & Net Outstanding & Includes Gold & \\
\hline 42 & October 19, 1907 & 0 & 0 & 2.25 & 10 & 0.018 & 1.3 & 11.175 & \\
\hline 43 & October 26, 1907 & 0 & 0 & 5 & 125 & -1.285 & 16.61 & -1.225 & \\
\hline 44 & November 2, 1907 & 1 & 3 & 3 & 75 & -1.765 & 57.235 & -38.825 & \\
\hline 45 & November 9, 1907 & 1 & 4 & 4 & 25 & 5.508 & 72.095 & -52 & \\
\hline 46 & November 16, 1907 & 2.5 & 4 & 5 & 15 & 26.619 & 80.185 & -53.725 & \\
\hline 47 & November 23, 1907 & 1.5 & 3.5 & 3.5 & 15 & 39.032 & 84.885 & -54.15 & \\
\hline 48 & November 30, 1907 & 0.75 & 1.75 & 3 & 12 & 55.578 & 84.595 & -53 & \\
\hline 49 & December 7, 1907 & 0.5 & 2 & 3 & 13 & 69.389 & 86.97 & -46.2 & \\
\hline 50 & December 14, 1907 & 0.5 & 1.5 & 2 & 25 & 78.856 & 87.32 & -40.1 & \\
\hline 51 & December 21, 1907 & 0.5 & 1.25 & 6 & 17 & 84.560 & 87.865 & -31.75 & \\
\hline 52 & December 28, 1907 & 0.25 & 1.25 & 6 & 25 & 88.675 & 86.495 & -20.225 & \\
\hline 1 & January 4, 1908 & 0.125 & 0.375 & 5 & 20 & 97.763 & 80.815 & -11.6 & \\
\hline 2 & January 11, 1908 & 0 & 0 & 2 & 9 & 101.390 & 68.345 & 6 & \\
\hline 3 & January 18, 1908 & 0 & 0 & 2.5 & 6 & 101.938 & 24.12 & 22.6 & \\
\hline 4 & January 25, 1908 & 0 & 0 & 1.5 & 3 & 102.313 & 6.65 & 37.1 & \\
\hline 5 & February 1, 1908 & 0 & 0 & 1.5 & 2 & 103.095 & 5.555 & 40.5 & \\
\hline \multicolumn{9}{|c|}{ Emboldened numbers denote observations indicating substantial financial distress. } & \\
\hline & Nen & ork Cle & House & an $\mathrm{Ce}_{\mathrm{C}}$ & ates & Reserve Def & alculated in $\mathrm{n}$ & $\pi$ & \\
\hline
\end{tabular}


Table 6a: Regression Results for Change in the Currency Premium Measure

\begin{tabular}{|c|c|c|c|c|}
\hline $\begin{array}{l}\text { Dependent } \\
\text { variable } \rightarrow\end{array}$ & $\begin{array}{c}\text { Change in } \\
\text { Currency } \\
\text { Premium } 1873\end{array}$ & $\begin{array}{c}\text { Change in } \\
\text { Currency } \\
\text { Premium } 1893\end{array}$ & $\begin{array}{c}\text { Change in } \\
\text { Currency } \\
\text { Premium } 1907\end{array}$ & $\begin{array}{c}\text { Change in } \\
\text { Currency } \\
\text { Premium } \\
\text { pooled sample }\end{array}$ \\
\hline Constant & $\begin{array}{l}-.36 \\
(.35)\end{array}$ & $\begin{array}{c}0.12 \\
(0.43)\end{array}$ & $\begin{array}{l}-0.03 \\
(0.23)\end{array}$ & $\begin{array}{l}-0.08 \\
(0.19)\end{array}$ \\
\hline $\begin{array}{l}\text { Change in } \\
\text { Reserves } 1873\end{array}$ & $\begin{array}{l}-0.09 \\
(0.06)\end{array}$ & & & \\
\hline $\begin{array}{l}\text { Change in } \\
\text { Reserves } 1893\end{array}$ & & $\begin{array}{c}-0.14 * * * \\
(0.05)\end{array}$ & & \\
\hline $\begin{array}{l}\text { Change in } \\
\text { Reserves } 1907\end{array}$ & & & $\begin{array}{c}-0.07 * * * \\
(0.01)\end{array}$ & \\
\hline $\begin{array}{l}\text { Change in } \\
\text { Reserves - } \\
\text { pooled sample }\end{array}$ & & & & $\begin{array}{c}-0.08 * * * \\
(0.017)\end{array}$ \\
\hline $\begin{array}{l}\text { Adjusted } \mathrm{R}^{2} \\
\text { D-W Statistic }\end{array}$ & $\begin{array}{l}0.22 \\
1.76\end{array}$ & $\begin{array}{l}0.33 \\
1.54\end{array}$ & $\begin{array}{l}0.44 \\
1.53\end{array}$ & $\begin{array}{l}0.37 \\
1.58\end{array}$ \\
\hline $\begin{array}{l}\text { Number of } \\
\text { observations }\end{array}$ & 6 & 6 & 10 & 22 \\
\hline
\end{tabular}

Note: Standard errors are estimated with the Eicker-White Heteroskedastic Consistent estimator.

*** denotes significance at the $1 \%$ confidence level. 
Table 6b: Regression Results for Change in the Currency Premium Measure Using the Change in the Reserve Surplus or Deficit relative to Required Reserves as Regressor

\begin{tabular}{|c|c|c|c|c|}
\hline $\begin{array}{l}\text { Dependent } \\
\text { variable } \rightarrow\end{array}$ & $\begin{array}{c}\text { Change in } \\
\text { Currency } \\
\text { Premium } 1873\end{array}$ & $\begin{array}{c}\text { Change in } \\
\text { Currency } \\
\text { Premium } 1893\end{array}$ & $\begin{array}{c}\text { Change in } \\
\text { Currency } \\
\text { Premium } 1907\end{array}$ & $\begin{array}{c}\text { Change in } \\
\text { Currency } \\
\text { Premium } \\
\text { pooled sample }\end{array}$ \\
\hline Constant & $\begin{array}{l}-.27 \\
(.37)\end{array}$ & $\begin{array}{c}0.15 \\
(0.46)\end{array}$ & $\begin{array}{l}-0.06 \\
(0.20)\end{array}$ & $\begin{array}{l}-0.05 \\
(0.20)\end{array}$ \\
\hline $\begin{array}{l}\text { Change in } \\
\text { Reserves in } \\
\text { surplus or deficit } \\
\text { of required } \\
\text { reserves } 1873\end{array}$ & $\begin{array}{l}-0.13 \\
(0.08)\end{array}$ & & & \\
\hline $\begin{array}{l}\text { Change in } \\
\text { surplus or deficit } \\
\text { of required } \\
\text { reserves } 1893\end{array}$ & & $\begin{array}{c}-0.12 * * * \\
(0.04)\end{array}$ & & \\
\hline $\begin{array}{l}\text { Change in } \\
\text { surplus or deficit } \\
\text { of required } \\
\text { reserves } 1907\end{array}$ & & & $\begin{array}{c}-0.07 * * * \\
(0.01)\end{array}$ & \\
\hline $\begin{array}{l}\text { Change in } \\
\text { Reserves - } \\
\text { pooled sample }\end{array}$ & & & & $\begin{array}{c}-0.07^{* * *} \\
(0.013)\end{array}$ \\
\hline Adjusted $\mathrm{R}^{2}$ & 0.22 & 0.18 & 0.56 & 0.35 \\
\hline D-W Statistic & 1.65 & 1.34 & 1.39 & 1.52 \\
\hline $\begin{array}{l}\text { Number of } \\
\text { observations }\end{array}$ & 6 & 6 & 10 & 22 \\
\hline
\end{tabular}

Note: Standard errors are estimated with the Eicker-White Heteroskedastic Consistent estimator.

*** denotes significance at the $1 \%$ confidence level. 
Figure 1: New York Stock Market, 1863-1909

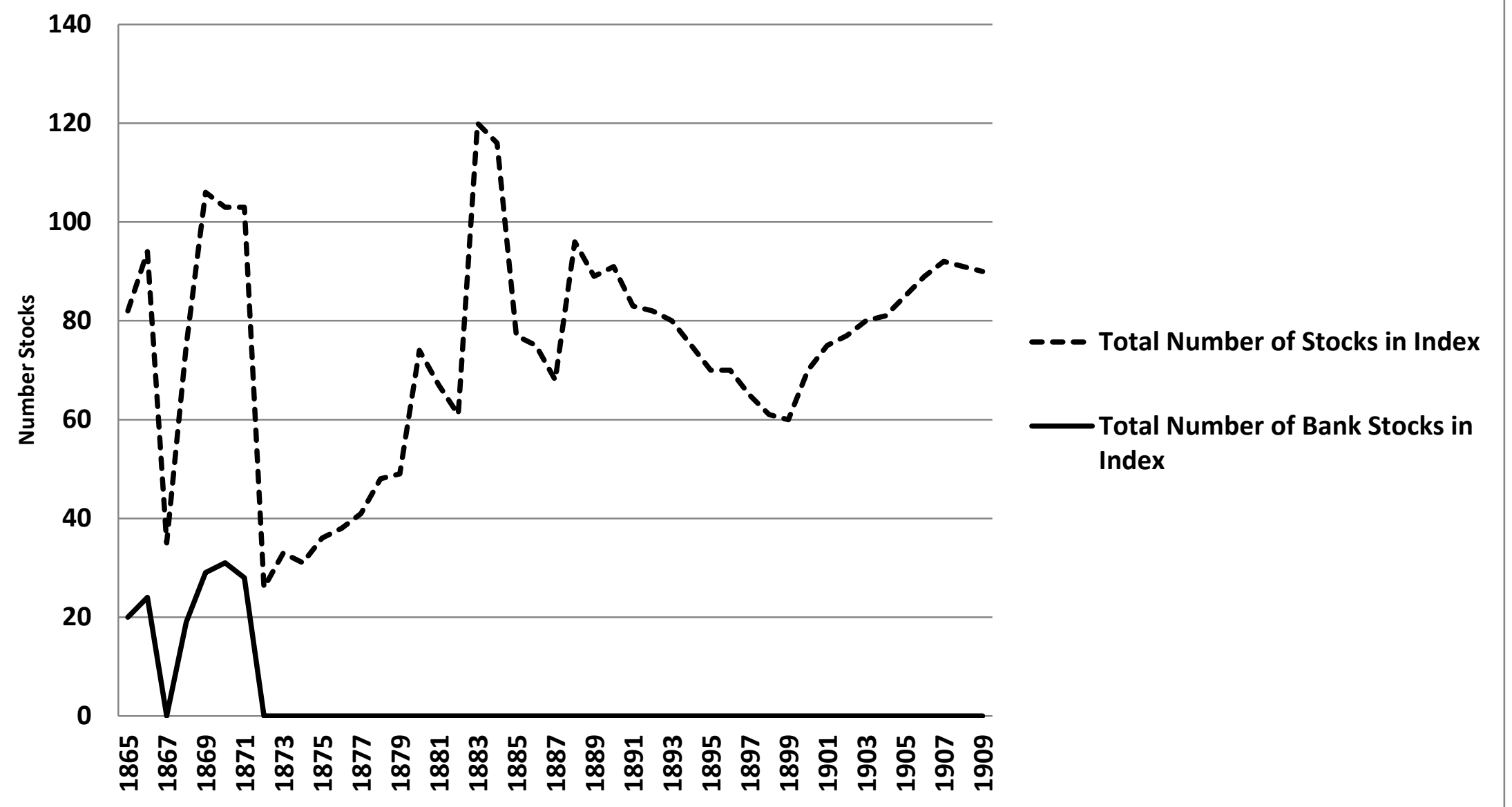




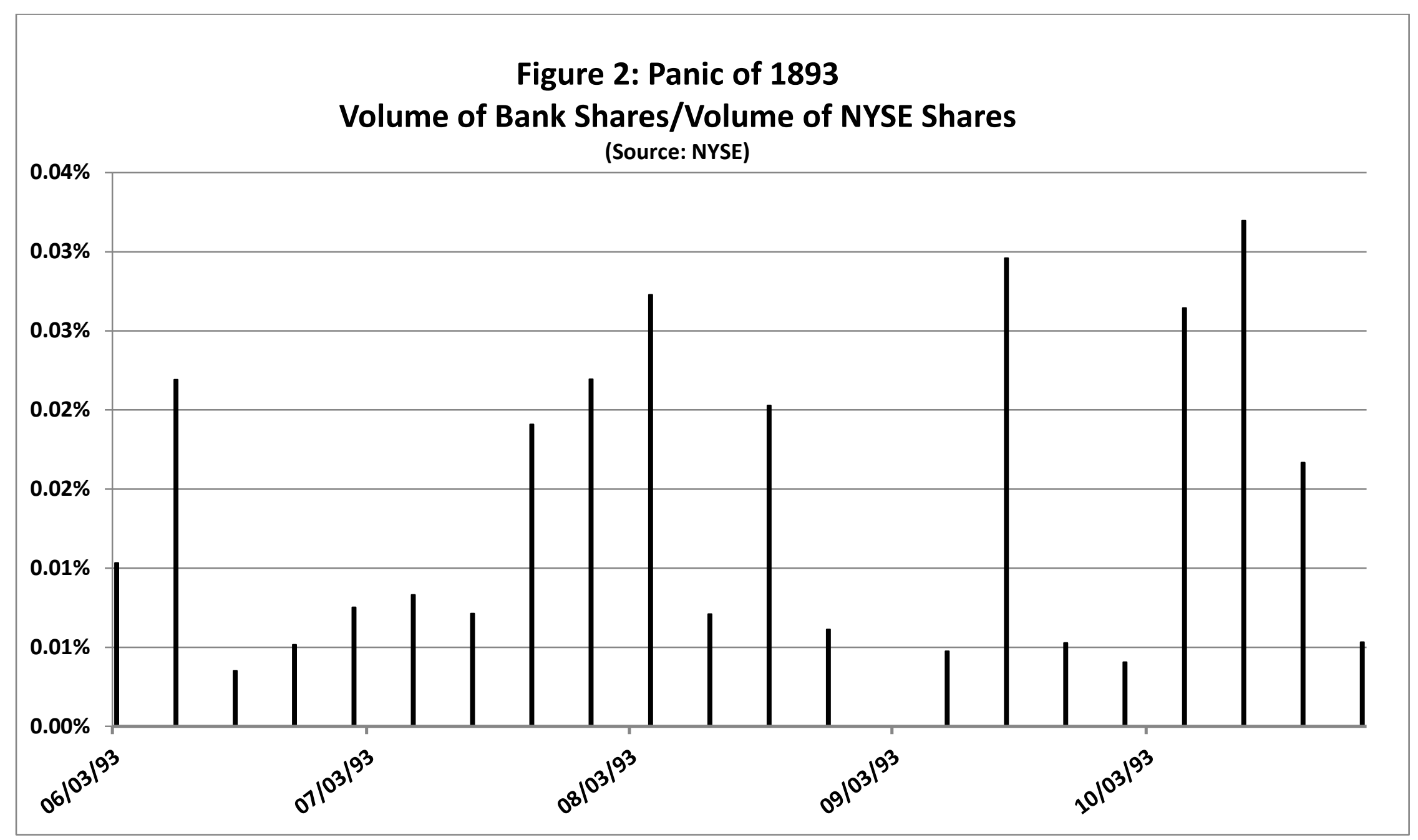




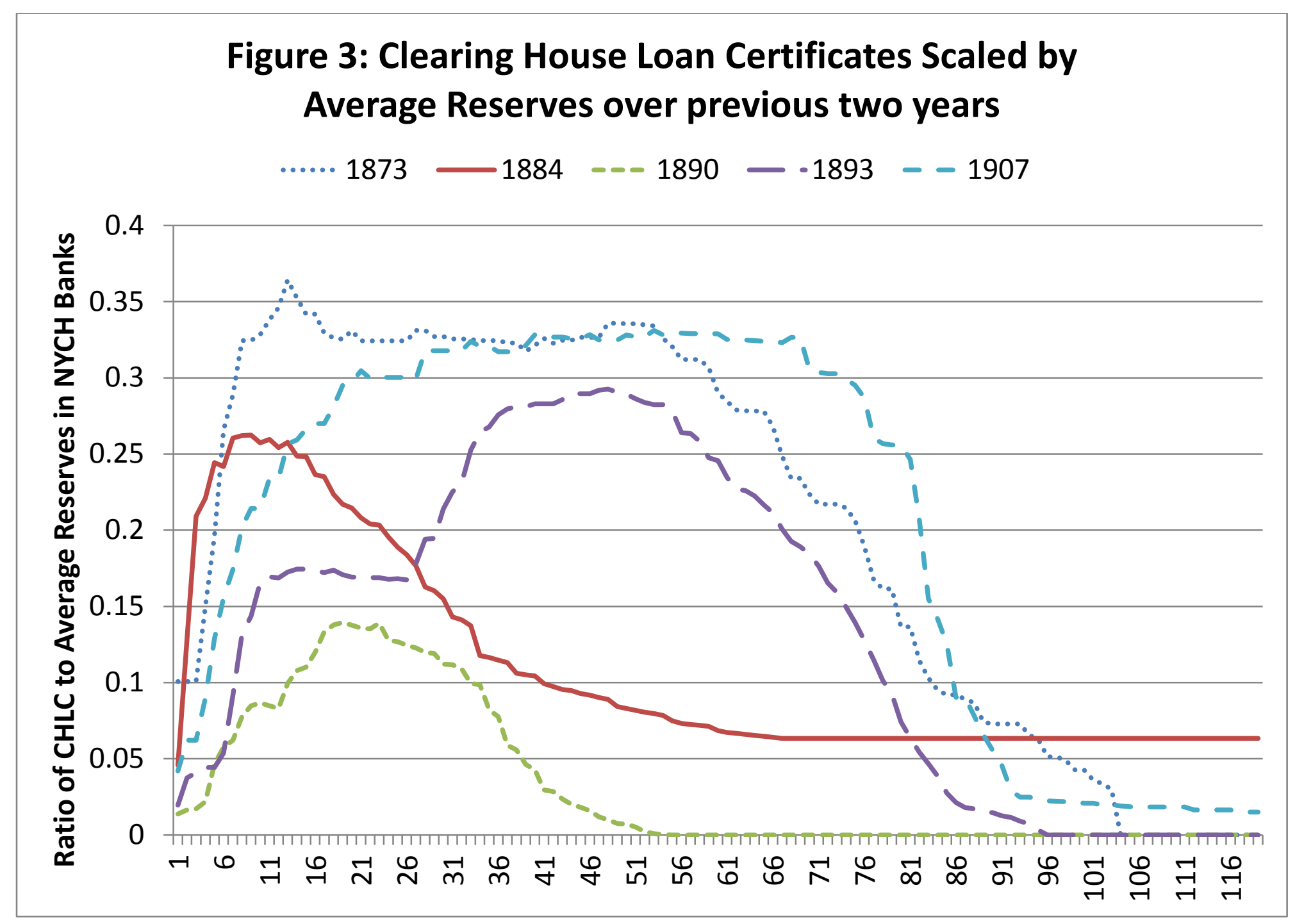

SOURCE: Minutes of the Clearing House Loan Committee, various dates, retrieved from the archives of the New York Clearing House. 


\section{Figure 4: Reserve Surplus versus Clearing House Loan Certificates Outstanding During Severe National Banking Era Panics}
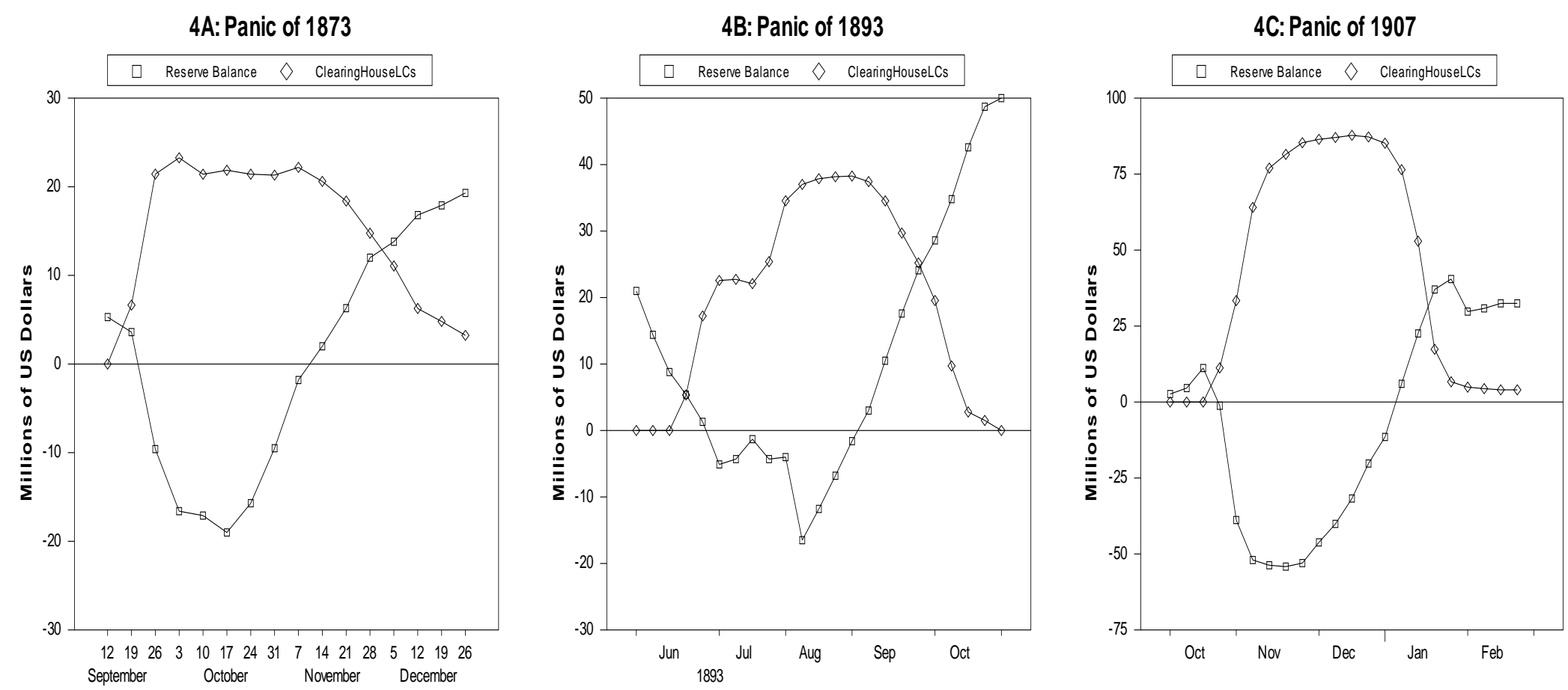

Source: A.P. Andrew (1910) and minutes of Clearing House Loan Committee, various dates 
Figure 5: Reserve Surplus versus Clearing House Loan Certificates Outstanding During Less Severe National Banking Era Panics
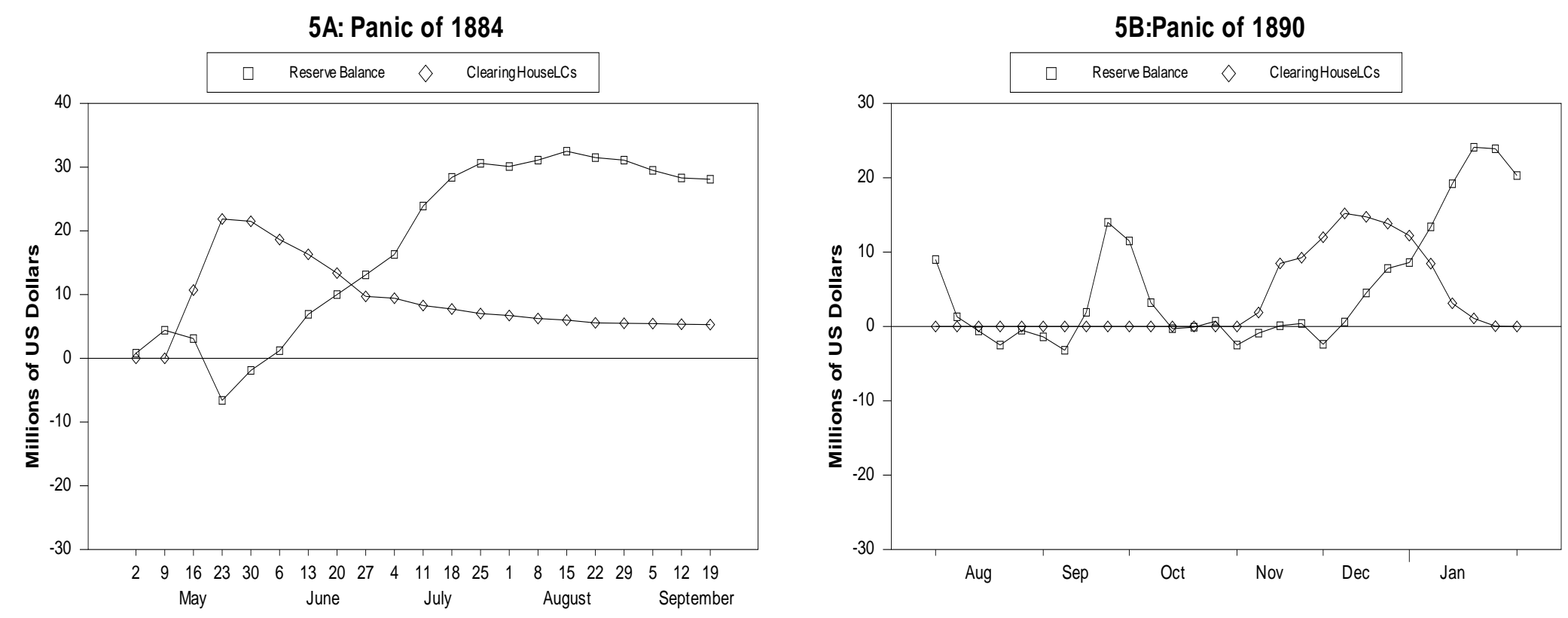

Source: A.P. Andrew (1910) and minutes of Clearing House Loan Committee, various dates 


\section{Figure 6: Certified Checks}
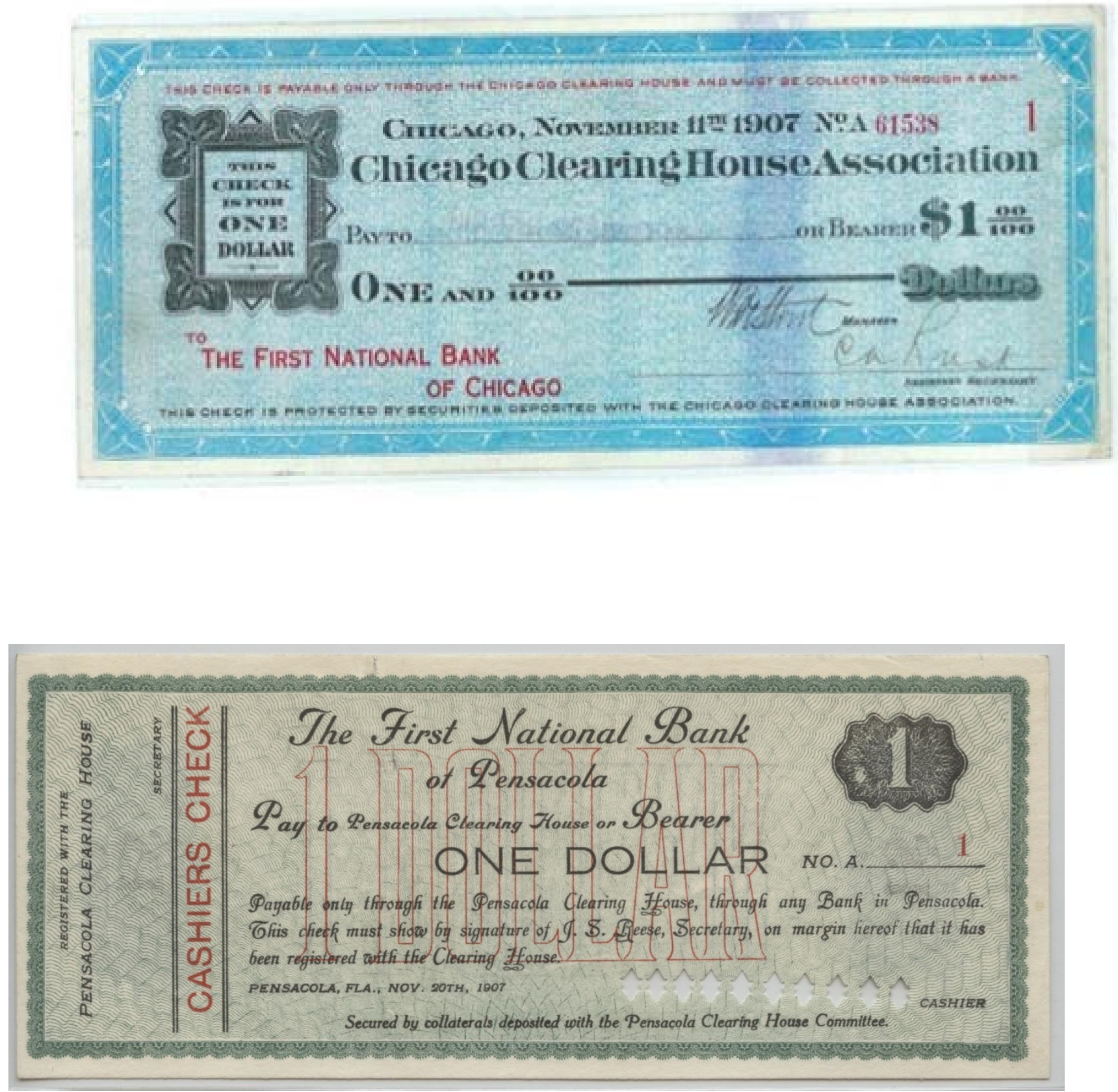

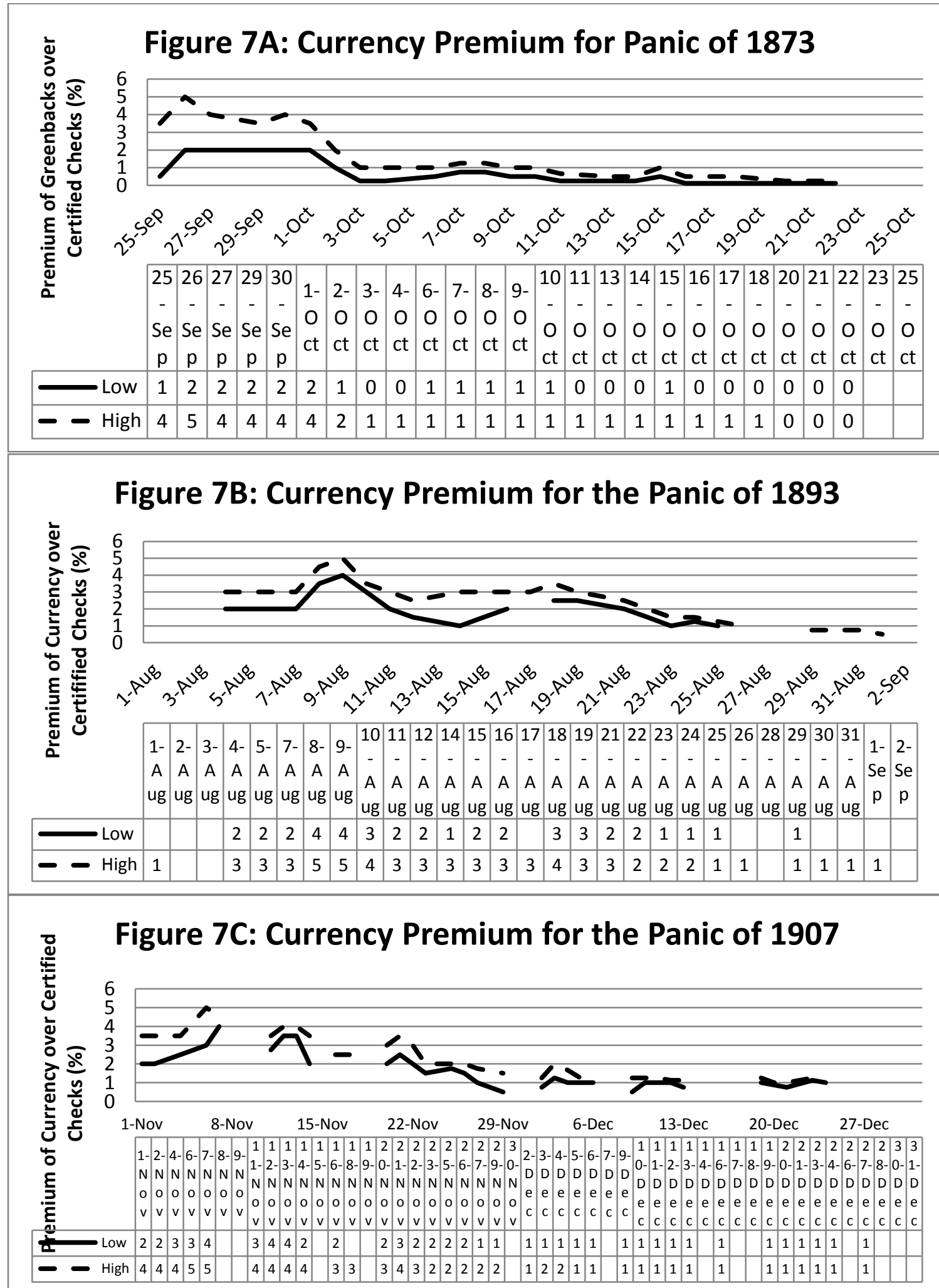

Source:

Tribune

and

Wall

Street

Journal. 


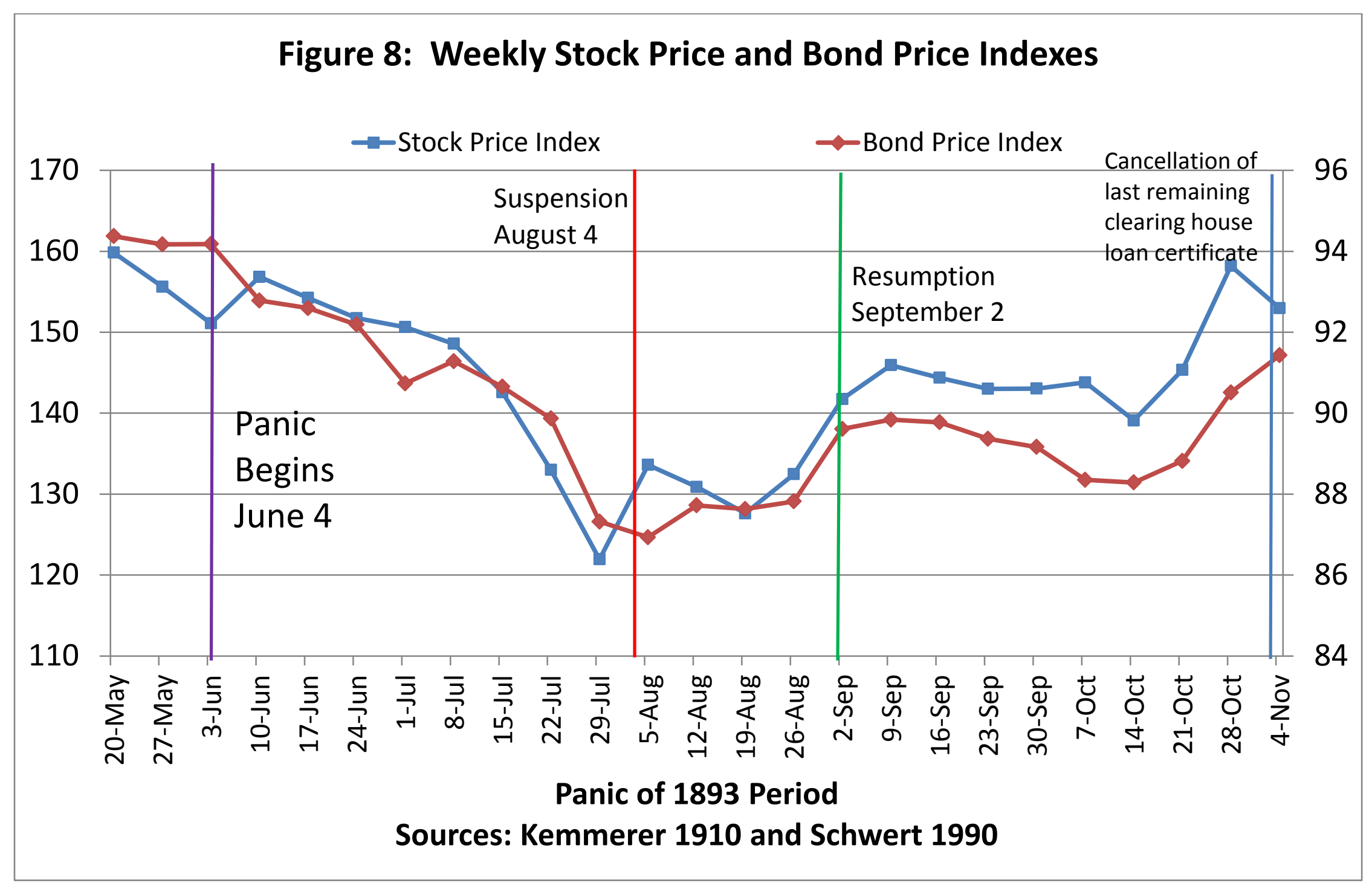




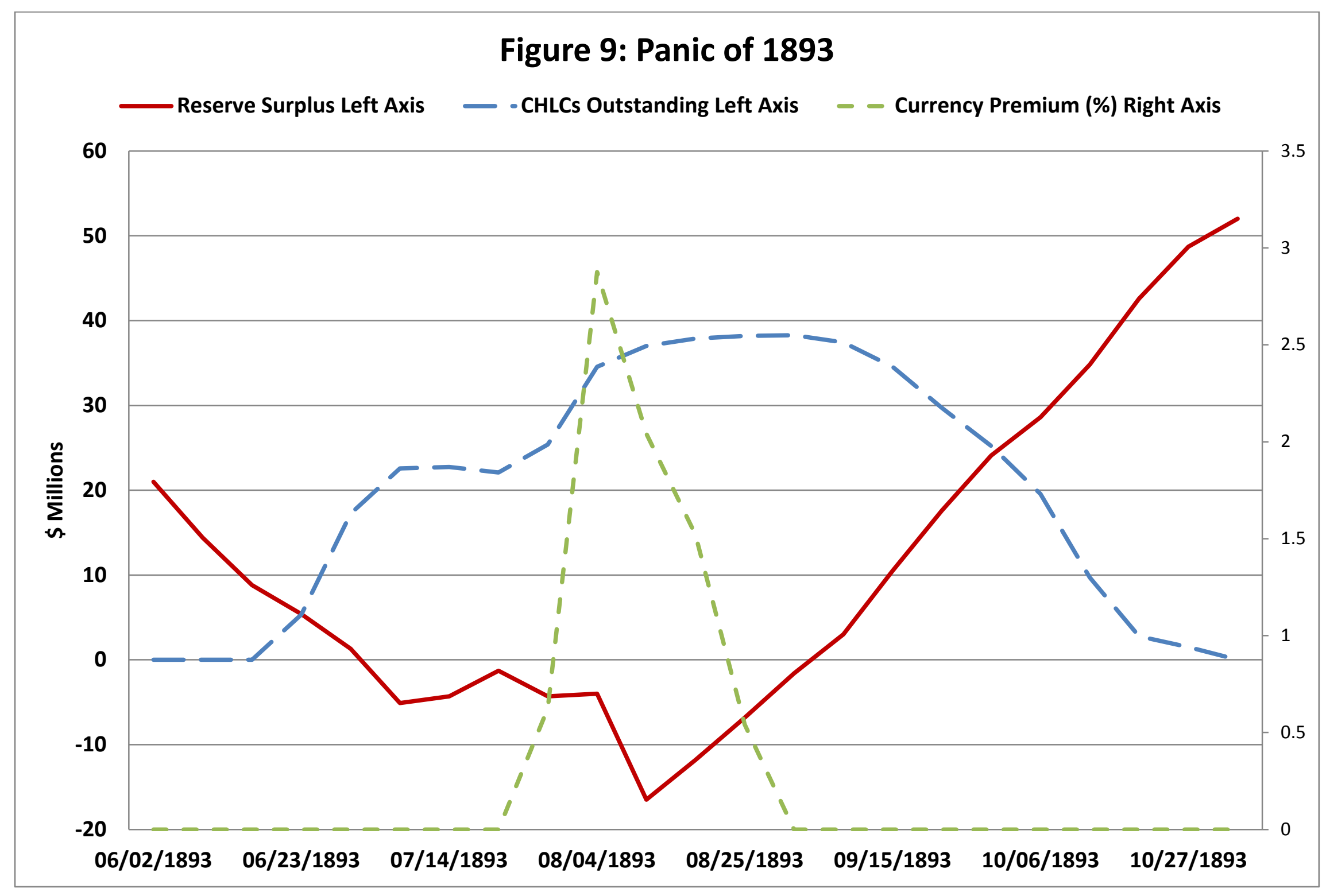




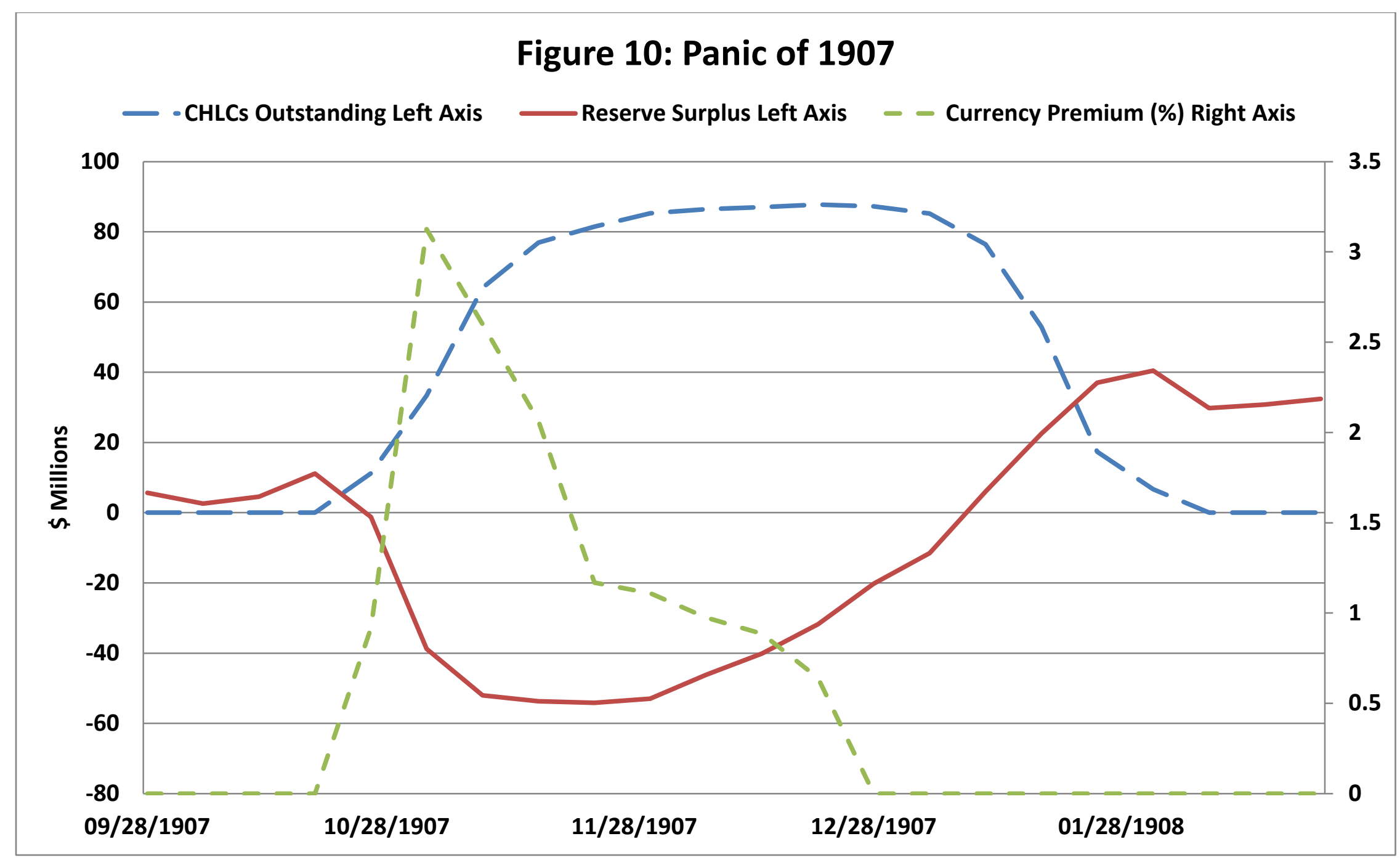




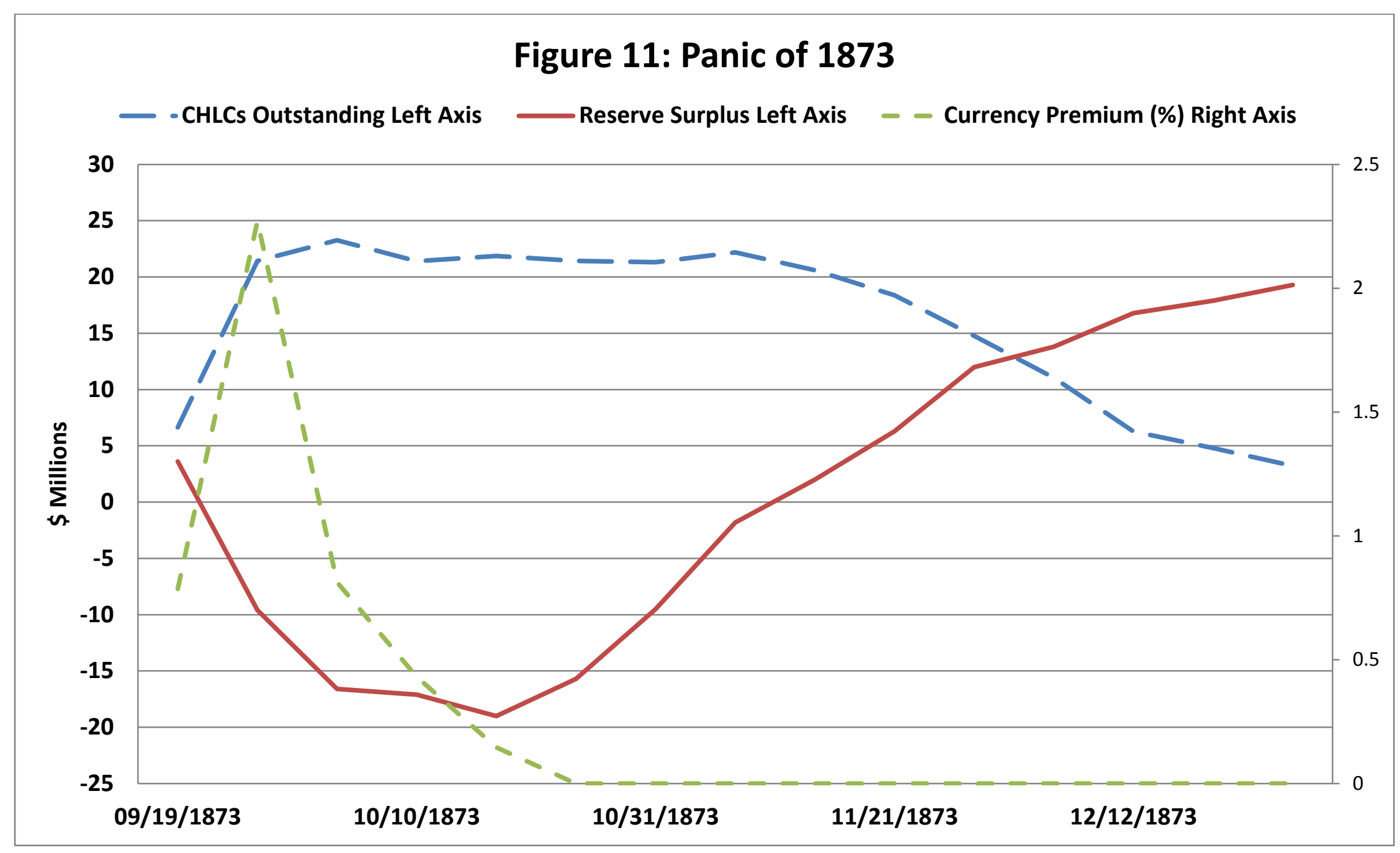

